\title{
Growing Season Changes over the Past Millennium in Northern High Latitudes
}

\author{
Fabian Everardus Zahit Ercan
}


ISBN: 978-90-6266-614-0

https://doi.org/10.33540/977

Published by Faculty of Geosciences, Universiteit Utrecht, The Netherlands, in: Utrecht Studies in Earth Sciences (USES), ISSN 2211-4335

Layout: F. E. Z. Ercan \& X. C. Z. M. Ercan

Cover and Invitation: F. E. Z. Ercan \& M. Stoete

This work is licensed under the Creative Commons Attribution 4.0 International License, https://creativecommons.org/licenses/by-nc-sa/4.0/.

(c) 2022 by Fabian E. Z. Ercan. 


\section{Growing Season Changes over the Past Millennium in Northern High Latitudes}

Veranderingen van het groeiseizoen gedurende het laatste millennium in het hoge Noorden

(met een samenvatting in het Nederlands)

\section{Proefschrift}

ter verkrijging van de graad van doctor aan de Universiteit Utrecht op gezag van de rector magnificus, prof.dr. H.R.B.M. Kummeling, ingevolge het besluit van het college voor promoties in het openbaar te verdedigen op

vrijdag 4 februari 2022 des middags te 2.15 uur

door

\section{Fabian Everardus Zahit Ercan}

geboren op 16 maart 1990

te Utrecht 


\section{| Promotor |}

Prof. dr. F. Wagner - Cremer

\section{| Copromotoren |}

Dr. D. Blok

Dr. W.Z. Hoek

Dit proefschrift werd (mede) mogelijk gemaakt met financiële steun van NWO beurs ALWOP.2015.110. 


\section{| Members of the Dissertation Committee |}

Dr. Leeli Amon

Tallin University of Technology - Estonia

Prof. Dr. Mary H. Gagen

Swansea University - Wales, UK

Prof. Dr. Wolfram M. Kürschner

University of Oslo - Norway

Prof. Dr. Hab. Mariusz Lamentowicz

Adam Mickiewicz University - Poznań, Poland

Prof. Dr. Hans Middelkoop

Utrecht University - The Netherlands 
Tundra and Taiga Through Time 


\section{Table of contents}

| Chapter 1 |

Introduction

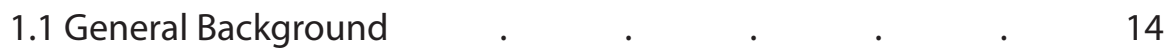

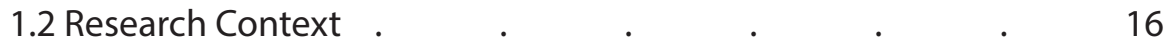

1.3 Research Questions and Thesis Outline . $\quad$. 20

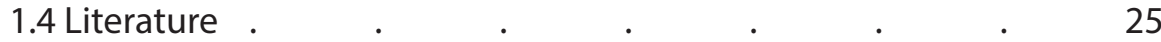

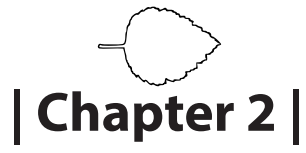

A growing degree day inference model based on mountain birch leaf cuticle analysis over a latitudinal gradient in Fennoscandia

34

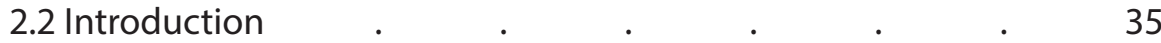

2.3 Materials and Methods $\quad$. $\quad$. $\quad$. $\quad$. $\quad$. 37

2.4 Results . . . . . . . . . . 40

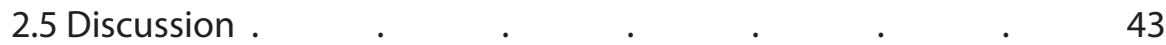

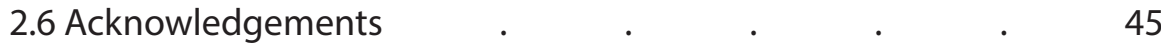

2.7 Literature . $\quad$. $\quad$. $\quad$. $\quad$. $\quad$. $\quad$. 45 


\section{| Chapter 3 |}

Effects of experimental warming on Betula nana epidermal cell growth tested over its maximum climatological growth range

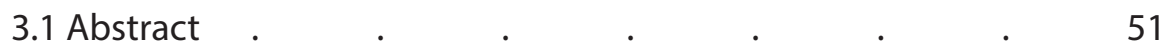

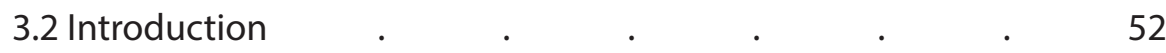

3.3 Materials and Methods $\quad . \quad$. $\quad$. $\quad$. $\quad$. 54

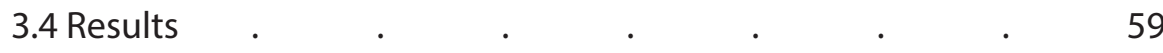

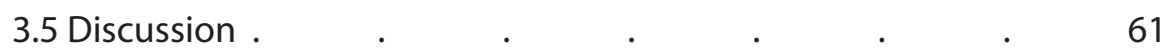

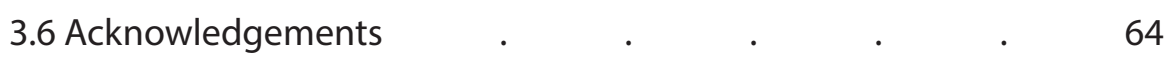

3.7 Literature . $\quad . \quad$. $\quad . \quad$. $\quad . \quad$. $\quad .65$

\section{Chapter $4 \mid$}

North Atlantic Oscillation seesaw effect in leaf morphological records from dwarf birch shrubs in Greenland and Finland

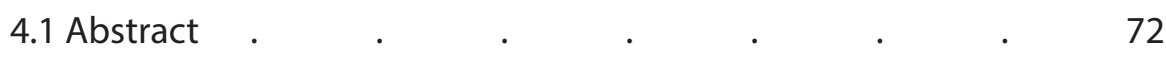

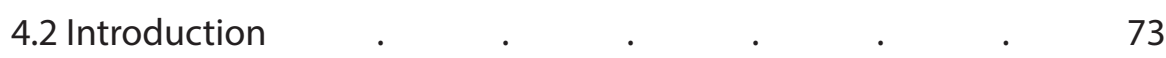

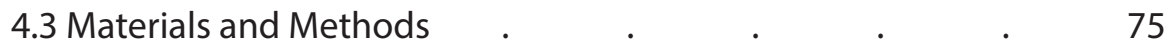

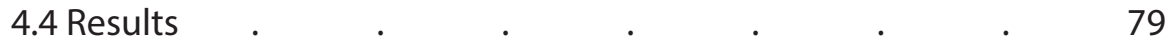

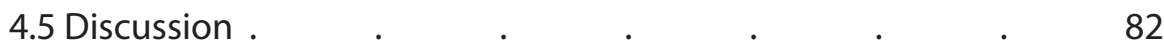

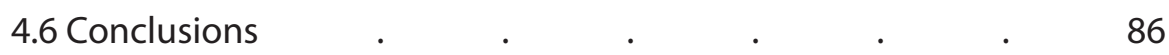

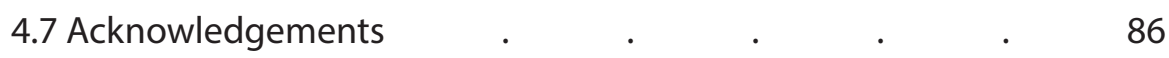

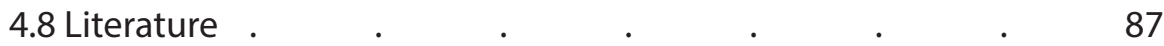




\section{| Chapter 5 |}

Limits of using Betula nana epidermal cell undulation for reconstructing extremely low thermal conditions

5.1 Abstract . $\quad . \quad$. $\quad . \quad$. . . $\quad$. 95

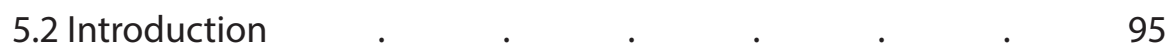

5.3 Materials and Methods $\quad . \quad$. $\quad$. $\quad$. $\quad$. $\quad 97$

5.4 Results . . . . . . . . . . . . 100

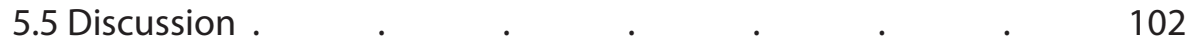

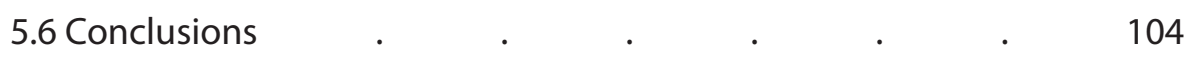

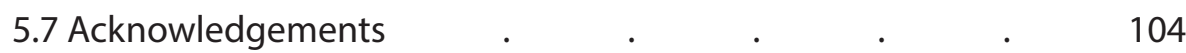

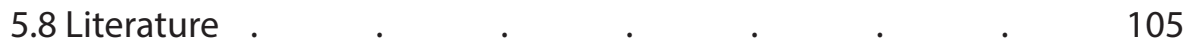

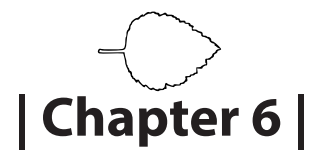

Spring temperature changes during the last 1300 years based on

Betula pubescens leaves from Denmark

6.1 Abstract . . . . . . . . . . . 110

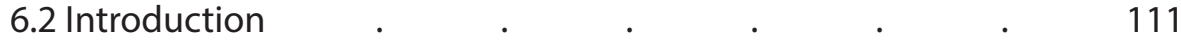

6.3 Materials and Methods . $\quad$. $\quad$. $\quad$. $\quad$. 113

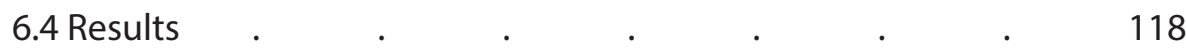

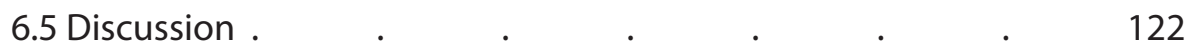

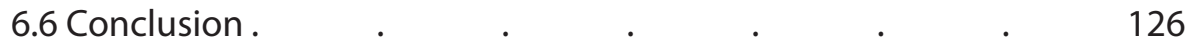

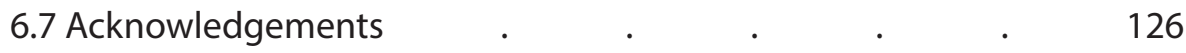

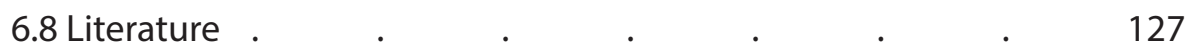




\section{| Chapter 7 |}

\section{Synopsis}

7.1 Thesis Summary

$\begin{array}{cccccc}. & . & . & . & . & 132 \\ . & \cdot & \cdot & . & . & 133 \\ . & \cdot & . & . & . & 135 \\ . & . & . & . & . & 136\end{array}$

\section{| Appendix |}

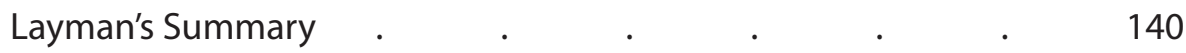

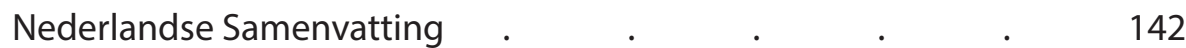

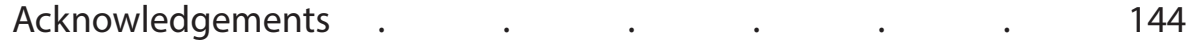

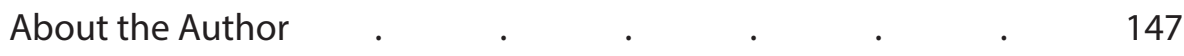

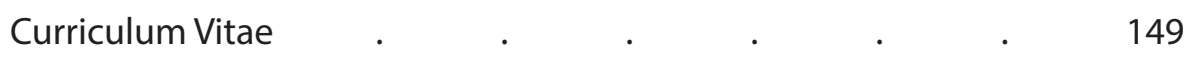

Fieldwork and Other Academic Activities 151

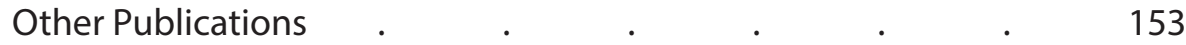

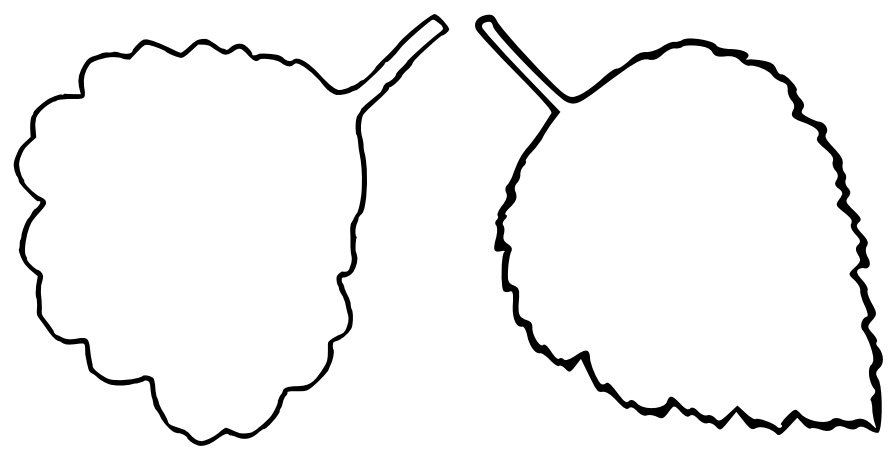




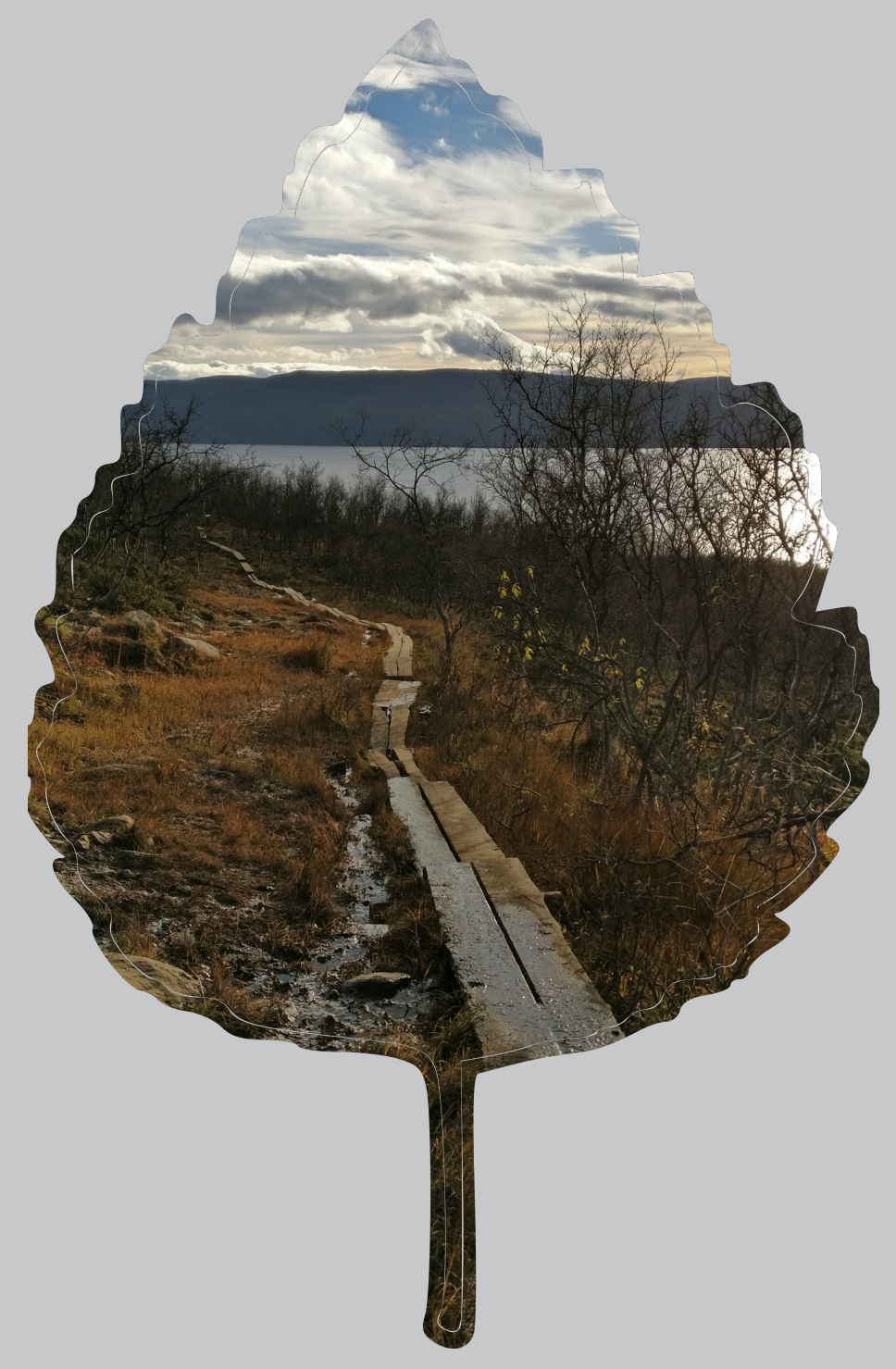




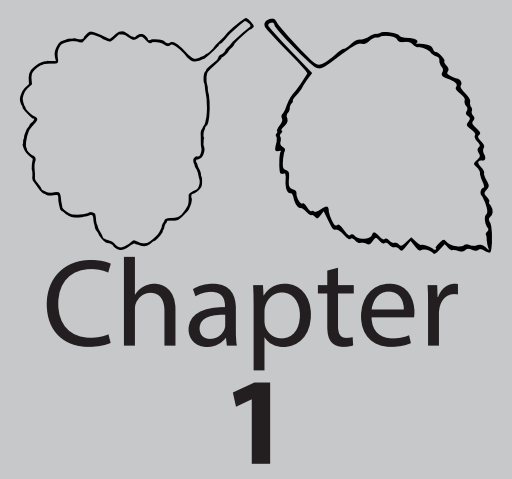




\section{Introduction}

\subsection{General Background}

The climate of planet Earth has varied throughout its history and will continue to change in the future. Earth's climate has just recently, 11,700 years ago, shifted from the last Ice Age epoch of the Pleistocene to the warmer period of the Holocene. The transition towards the Holocene marked the beginning of the modern climate era and the onset of human civilizations. Naturally occurring climatic shifts like this are attributed to changes in the global distribution of solar energy that is received by the planet, where energy differences are caused by variations in the Earth's orbit around the Sun, axis of rotation and tilt. These variations, called Milankovitch cycles, govern climatic shifts over large time scales and the varying position of the Earth relative to the Sun within one orbital revolution is also the cause of yearly seasonal changes (Mayewski et al. 2004; Wu et al. 2018). On Earth, the atmosphere, biosphere, cryosphere, oceans, and landmasses constantly interact with each other through positive and negative feedback mechanisms by distributing the energy received from the Sun. The interplay between these facets of the planet, govern our climate which is the long-term expression of the daily weather. The Earth System formed by complex atmospheric and oceanic interactions between energy, humidity, and temperature lead to vast variations in daily weather, and indeed a varying average of weather over time: the climate (Steffen et al. 2020). Climate variations are moreover on short term affected by changes in sunspot activity or incidental volcanic eruptions (Salzer and Hughes 2007; Ahmed et al. 2013). The interannual variability of climate is largely governed by circulation patterns in the atmospheric and oceanic systems, transporting heat and humidity over the planet over large distances, via so called teleconnections (Franzke and Feldstein 2005).

An important example of a teleconnection system is the North Atlantic Oscillation (NAO), see figure 4.1. The NAO affects System Earth by producing important climatic effects throughout the Northern Hemisphere (Visbeck et al. 2001; Hurrell 2005; Trouet et al. 2009; Li et al. 2016; Hanna and Cropper 2017). An atmospheric pressure gradient between the subtropical high (between the Azores and Gibraltar) and the Icelandic low (between Iceland and Greenland) cause the teleconnection pattern. When the pressure difference between the two systems is large (the so-called positive NAO phase), heat and humidity transport to northern Europe ensues, resulting in a warm, wet, and stormy winter and spring in northern 
Europe. Simultaneously, relatively dry and colder conditions are observed in the Mediterranean region and across the Atlantic Ocean in Greenland. During a negative NAO phase, the pressure gradient in the atmosphere between the subtropical high and the Icelandic low is less pronounced, and the weather patterns are reversed.

Climate change has a strong effect on human society and culture, especially since the development of agriculture and civilisation about 10,000 years ago in the Middle East. The more forgiving climate of the Holocene allowed plants and animals to be domesticated, and a nomadic lifestyle was abandoned in favour of permanent settlement for the first time in the area known as the Fertile Crescent (Brown et al. 2009). Civilisations have ever since thrived or declined under the effects of climatic shifts, due to the large agricultural dependence on weather and seasonality (Berglund 2003; Zhang et al. 2011; Kelley et al. 2015; Ljungqvist et al. 2018; Clayton 2020; Thomson and MacDonald 2020; Büntgen et al. 2021; Ljungqvist et al. 2021a; Ljungqvist et al. 2021b).

Today, in a time of rapidly changing climate, which is largely attributed to human activities, there is great interest in the impact of climate change on human society and the natural world. In an attempt to understand the Earth System, and the impact of change on human civilisation, scientific efforts are undertaken towards monitoring and modelling climate change (Ruddiman 1990; Trouet and Van Oldenborgh 2013). To determine changes in such a chaotic system, a long period of time needs to be studied. Historic and contemporary records of (daily) weather and weather-related phenomena are complemented by the modern observations of Earth-orbiting satellites that have been available since the later part of the 20th century. However, to form a more complete picture of climate change and its causes and effects, these observations need to be supplemented with proxy records (Van Der Burgh et al. 1993; Kürschner et al. 1996; Hoek and Bohncke 2002; Wagner et al. 2002; Visscher et al. 2004; Kouwenberg et al. 2005; van Hoof etal. 2006; Salzer and Hughes 2007; Donders et al. 2008; Sluijs et al. 2009; Wagner-Cremer et al. 2010a; Cramwinckel et al. 2018; Fischer et al. 2018; Gouw-Bouman et al. 2019; Ahmed et al. 2020).

Examples of proxy records relevant to reconstructing past climate conditions include the study of atmospheric gasses trapped in ice cores, the width and quality of annual tree rings and analysis of species composition in fossil records. Many proxies are based on biological traits, on the remains of organisms or their fossil traces. Plants and animals are in constant struggle to maintain homeostasis to 
preserve their vital functions and will adapt and change over time to achieve this. An individual organism will adapt if it can, a species as a whole will adapt through means of evolution over larger courses of time, and entire ecosystems can change in their species composition and productivity. Coupling known climatic conditions to observed biologic configurations allows for proxy calibration (Wagner-Cremer et al. 2010b; Heiri et al. 2014; de Boer et al. 2016; Hincke et al. 2016). This subsequently allows the determination of past climatic conditions, based on biologic proxies. Climatic conditions that can to date be reconstructed include, but are not limited to: temperature, humidity, light availability, atmospheric $\mathrm{CO}_{2}$-concentrations, salinity, and nutrient availability.

\subsection{Research Context}

The vegetation growing season length and thermal intensity are very important aspects of climate since the growing season has vast influence on society and the environment. Growing season physical properties determine whether there is enough light and heat available for seasonal development of plants, which in return affects both the carbon and hydrological cycles and eventually agricultural performance. Meteorological observations confirm that the growing season is currently lengthening because of a warmer global climate (D'Odorico et al. 2002; Menzel et al. 2006; Reyes-Fox et al. 2014; Liu et al. 2018; Steinthorsdottir and Wagner-Cremer 2019). Especially in the European northern high latitudes, this warming in early spring is rapidly accelerating, noticeable in greatly altered vegetation dynamics, influencing the entire ecosystem. Higher temperatures and an extended growing season in the European high latitudes now enable plants to perform better or even extend their occurrence range, a process called Arctic Greening (Blok et al. 2011; Raynolds et al. 2013; Guay et al. 2014; Hollesen et al. 2015; Fauchald et al. 2017; Magnússon et al. 2020). In the northern Atlantic region, much of the growing season properties are influenced by the NAO. To track the impact of such atmospheric pressure systems, their behaviour and extent over a multi decadal to centennial time scales need to be quantified and understood.

Research incorporating palaeobotanical techniques allows for reconstructions beyond the short-term coverage of satellite records and are particularly useful in areas with little or no long historical weather records, such as in the Arctic. Accurate reconstructions of past growing season properties can be achieved by a recently developed palaeobotanical technique using the micro-phenology of modern and 
fossil leaves (Wagner-Cremer et al. 2010). This technique allows for reconstruction of the growing season in the past, exploring (sub-)fossil leaves and historical leaf specimens preserved in herbaria.

The so-called Undulation Index (UI) proxy quantifies the shape of epidermal cells in birch (Betula, Box 1) leaves and is highly sensitive to Growing Degree Day (GDD) changes (Wagner-Cremer et al. 2010b). GDD, Box 2 is a measure for the cumulative sum of degree Celsius during the year, where a biologically relevant temperature threshold is commonly used as baseline in order to determine the annual 'sum' of temperature (McMaster and Wilhelm 1997; Miller et al. 2001). The UI, Box 3 quantifies the cell matureness or developmental stage by measuring the undulation ("waviness") of epidermal pavement cells on the leaf surface (Kürschner 1997). If more time, water, nutrients, and energy are available to a deciduous plant, it is expressed in more and healthier leaves, permitting more photosynthesis allowing for higher investments in growth. In birch, this growth is expressed and measurable in higher undulation of the epidermal cells, forming a proxy where mainly seasonal temperature is of direct influence on the quantified parameter. Birch, Betula pubescens and Betula nana and their hybrids (Mountain Birch, $B$. pubescens $\times$ nana) are common species in northern latitudes and frequently occur in north-western Europe (B. pubescens, B. nana \& B. pubescens $\times$ nana) and Greenland ( $B$. nana) in the current vegetation as well as in in the fossil record, making this genus very useful to study growing season changes in those areas (Habjørg 1971; Wagner et al. 2000). 


\section{Box 1: Birch in the context of this thesis.}

Birch is a deciduous tree in the genus Betula, in the family of Betulaceae. Birches are widespread in the higher latitudes of the Northern Hemisphere, in temperate or boreal climates, often function as pioneer species and have mycorrhizal symbiosis. Birches generally are shade intolerant and prefer acidic and well drained conditions. The three species that occur in northwestern Europe are Silver Birch (Betula pendula Roth, 2n), Downy Birch (Betula pubescens Ehrh., 4n), and Dwarf Birch (Betula nana L., 2n). B. pendula and $B$. pubescens both grow as trees in overlapping habitats, while $B$. nana grows as a dwarf shrub in tundra and alpine environments, including Greenland. $B$. pubescens and $B$. nana are known to hybridise in various combinations and degrees, forming $B$. nana $\times$ pubescens and $B$. pubescens $\times$ nana triploid $(3 n)$ hybrids, referred to as $B$. pubescens spp. czerepanovii (N.I.Orlova) Hämet-Ahti. In this thesis, only $B$. pubescens, $B$. nana and $B$. pubescens spp. czerepanovii are used as paleobotanical proxy species for climatic conditions in the past. To securely determine (fragmented) birch leaves from fossil material, the stomatal length provides a good control measure as $B$. pendula has significantly smaller stomata than B. pubescens, B. nana and their hybrids (Wagner et al. 2000).
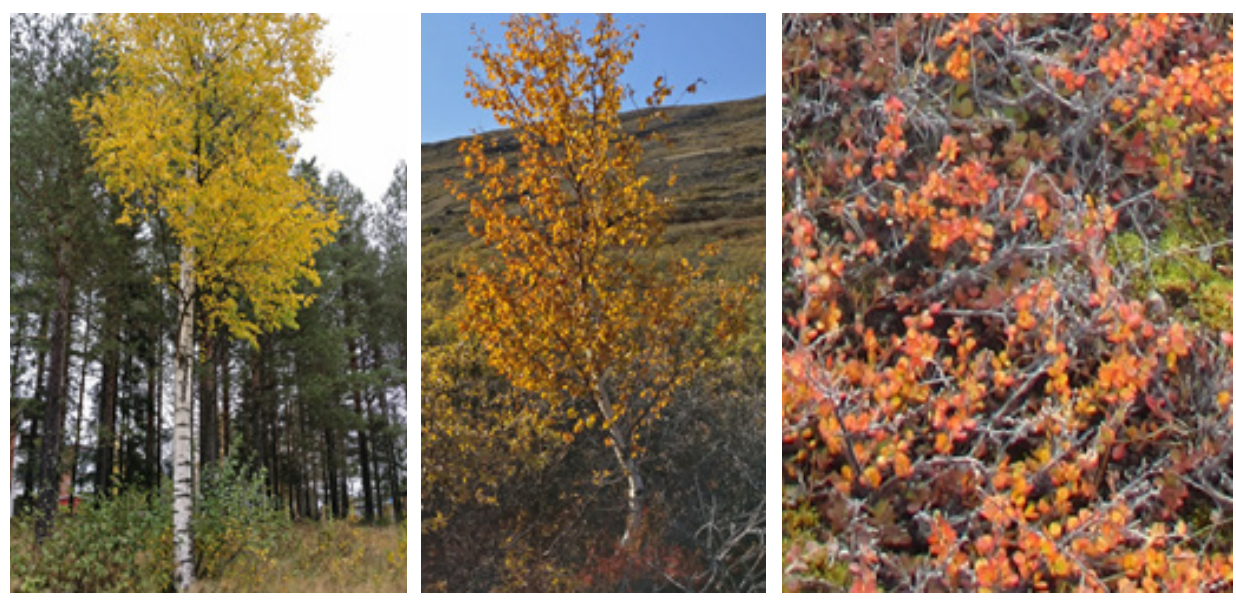

Left to right: Betula pubescens (southern Finland), B. pubescens spp. Czerepanovii (northern Finland), B. nana (western Greenland). Notice how Betula pubescens colours yellow in autumn, and B. nana colours red, while the hybrid B. pubescens spp. czerepanovii occurs in various degrees of orange. Own photographs from fieldwork areas in Finland and Greenland. 
Box 2: GDD in the context of this thesis.

$$
G D D_{X}=\sum_{i=1}^{\# \text { days }}\left(T_{i}-X\right), \quad T_{i} \geq X
$$

$\mathrm{GDD}_{\mathrm{x}}$ covers the growing potential for vegetation in a given year and is expressed by the cumulative sum of degrees Celsius above a determined base temperature (X) (McMaster and Wilhelm 1997; Weijers et al. 2013) where $T_{i}$ is the daily mean temperature for day $i$ and $X$ is the selected threshold temperature in degrees Celsius. For $T_{i}$, the daily mean temperature from each station was used. For the latitudinal range and species covered in this thesis, $5^{\circ} \mathrm{C}$ is the commonly used threshold temperature for plant growth and is taken as threshold temperature $X$, resulting in GDD5 (Carter 1998).

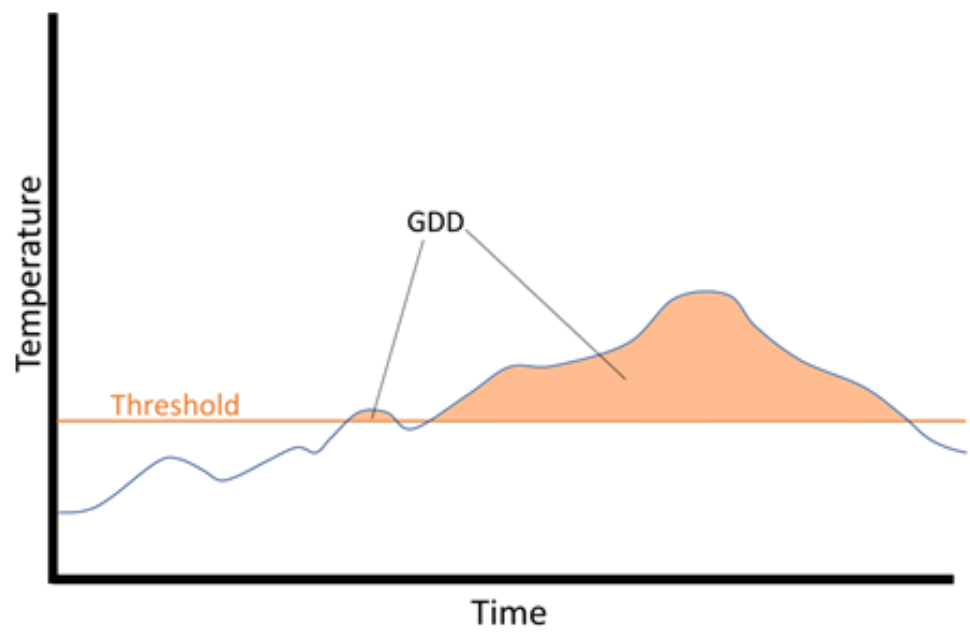

In this graph, the GDD accumulation during a hypothetical year is shown.

To compute GDD for a given year, continuous daily temperature data of that year is needed. This data is mostly retrieved from the KNMI Climate Explorer web application (climexp.knmi.nl), a service run by the KNMI in the context of the WMO Regional Climate Centre. It is important to retrieve data from the most relevant meteorological station, often the one closest to the study site, but also with a long enough record. 
Box 3: Undulation Index in the context of this thesis.

$$
U I=\frac{C C}{2 \pi \sqrt{\frac{C A}{\pi}}}
$$

Equation for the calculation of the dimensionless undulation index (UI) based on the mean circumference $(\mathbf{C C})$ and the mean area (CA) of the epidermal cells (Kürschner 1997).

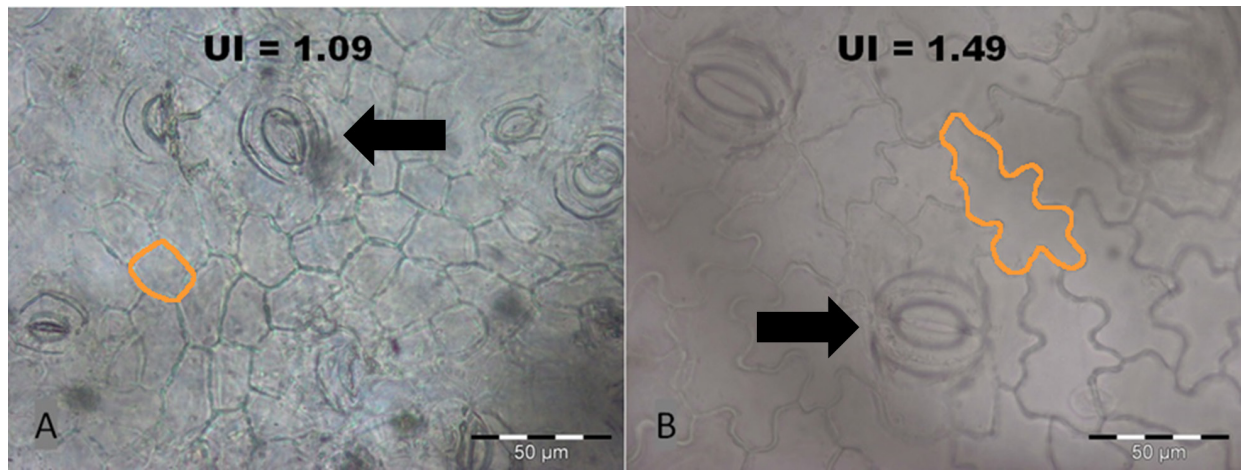

A: B. nana epidermal cells with low UI.

B: B. nana epidermal cells with very high UI.

Orange encirclements indicate epidermal cells, the black arrows point to a stomatal cell.

Occurrence of lower UI (less developed/undulated epidermal cells) generally indicates a colder or shorter growing season in contrast to higher UI (more developed/undulated epidermal cells), indicating warmer or longer growing conditions.

\subsection{Research Questions and Thesis Outline}

The impact of climate change is affecting the ecosystems of northern high latitude regions greatly influencing seasonality (Vinther et al. 2010; Jones et al. 2014; Niedźwiedź et al. 2014; Box et al. 2019). Particularly the dynamics of late winter and early spring are rapidly changing, where the timing of snow melt ushers the onset of spring and the start of the growing season is so delicately timed amongst species, influencing the whole ecosystem (Chae et al. 2014; Shen et al. 2014; Niskanen et al. 2019). This lengthening and warming of the growing season is projected to continue in the future (Bintanja and Andry 2017; Bintanja et al. 2020). Knowing 
the dynamics of the climate of the pre-industrial past helps to understand the natural interactions between climate and the ecology (Jones et al. 2014; Niskanen et al. 2019). So far, the early part of the growing season (March-April-May) was underrepresented in proxy-based reconstructions in high latitudes. The innovative birch leaf-based UI technique is sensitive to the early spring temperature dynamics and is applicable by retrieving preserved leaf material from herbaria or as fossils from natural sedimentary archives (Wagner-Cremer et al. 2010b; Finsinger et al. 2013).

The relevance of the research presented in this thesis was sparked by the need for insight in natural growing season dynamics in northern high latitude areas, mainly focusing on both sides of the NAO see-saw, western Greenland and north-western Europe.

This thesis aims to infer spring dynamics in the past, and to draw conclusions about future plant performance and climate change. Additionally, this thesis aims to further validate and test the GDD sensitivity of the UI in birch by analysing the past and present functioning of plants in relation to climate and (early) growing season dynamics.

From the reasoning above, the following questions are postulated;

\section{Research Questions}

To what extent is the Birch based UI proxy suitable to reconstruct early growing season change in northern high latitudes?

How will Betula nana and Betula pubescens react to future climate warming in terms of increased plant performance?

Is the UI proxy suitable to reconstruct NAO dynamics on both sides of its see-saw pattern (Northern-Europe and Western-Greenland)?

In terms of Ul-reconstructed early growing season dynamics, how does temperature fluctuate in pre-industrial north-western Europe?

These research questions will be answered in this thesis, divided in the chapters listed on the next page. 


\section{Thesis outline:}

\section{Chapter 2}

\section{A growing degree day inference model based on mountain birch leaf cuticle analysis over a latitudinal gradient in Fennoscandia}

Previously, the birch-based epidermal UI proxy has only been available for B. nana. In this chapter, the response of UI to GDD has been parameterized for $B$. pubescens (including B. pubescens spp. czerepanovii). An inference model has been established by measuring the $\mathrm{UI}$ response on a GDD gradient though Fennoscandia, a $10^{\circ}$ latitudinal transect translating to a range from $\sim 1500^{\circ} \mathrm{C}$ to $\sim 600^{\circ} \mathrm{C}$ GDDs. This inference model enables the future use of $B$. pubescens $\mathrm{UI}$ in GDD reconstructions.

This chapter is published as:

Ercan FEZ, De Boer HJ and Wagner-Cremer F (2020) A growing degree day inference model based on mountain birch leaf cuticle analysis over a latitudinal gradient in Fennoscandia. Holocene 30(2).

\section{Chapter 3}

\section{Effects of experimental warming on Betula nana epidermal cell growth tested over its maximum climatological growth range}

In this chapter, the response of $B$. nana epidermal cell Ul in experimental and natural settings are compared between three locations. One research site in northern Finland, where B. nana enjoys optimal growth conditions, one research site in western Greenland, where B. nana survives under sub-optimal growth conditions and one research site in northern Poland, where B. nana occurs in a relict stand, a remainder of a population in glacial times. This research aims at understanding $B$. nana UI response to GDD in different parts of its occurrence range and the generality of the response over large geographical regions.

This chapter is published as:

Ercan FEZ, Mikola J, SilfverT, Myller K, Vainio E, Słowińska S, Słowiński M, Lamentowicz $M$, Blok D and Wagner-Cremer F (2021) Effects of experimental warming on Betula nana epidermal cell growth tested over its maximum climatological growth range. PLOS ONE 16(5): 1-12. 


\section{Chapter 4}

\section{North Atlantic Oscillation seesaw effect in leaf morphological records from} dwarf birch shrubs in Greenland and Finland

As the NAO determines much of the weather in northern Atlantic regions, it is vital to understand the role of the NAO in climate change. This chapter presents B. nana $\mathrm{UI}$ as a NAO-sensitive proxy to aid NAO analysis in the future, and to demonstrate the influence of NAO on plant phenology. The suitability of the epidermal UI proxy to reconstruct the NAO is tested by the analysis of $B$. nana UI from Greenland and Finland. These regions are characterized by the 'see-saw' expressions of the NAO system. Opposite UI responses are expected, as the NAO imposes opposite weather conditions in Finland compared to Greenland. During a positive NAO, the weather conditions are warmer in Finland and colder in Greenland, during a negative NAO phase, weather conditions are colder in Finland and Warmer in Greenland. The UI proxy is shown to be sensitive for historically documented and modelled changes in NAO phase and intensity, reaching back in time till the 1860's (Common Era).

\section{Chapter 5}

\section{Limits of using Betula nana epidermal cell undulation for reconstructing extremely low thermal conditions}

This chapter adds important knowledge on the constraints and applicability of the $B$. nana UI proxy. It is important to test biological proxies for their sensitivity and accuracy, and as such, the $B$. nana $\mathrm{UI}$ is tested on its responsiveness to GGD variation in very cold circumstances. This is achieved by numerically analysing the lower response rate of $U I$ in $B$. nana in natural and experimental settings, ensuring the applicability to a wide range of situations, including the analysis of past events of climatic warming or cooling.

\section{Chapter 6}

\section{Spring temperature changes during the last 1300 years based on Betula pubescens leaves from Denmark}

Over the last centuries, major societal changes have been caused by relative minor climatic shifts. Agriculture-based societies are highly susceptible to such climatic shifts, and much is to be learned from the past in this regard. The B. pubescens UI 
proxy is sensitive to the intensity of the entire growing season and is very suitable for reconstructions in the context of agriculture and society. In this chapter, a growing season reconstruction from western Denmark spanning the last 1300 years is presented. This detailed record, based on B. pubescens epidermal UI, agrees with comparable records of the wider geographical area, and allows for linkage with socio-economic historical events and climatic periods over the last $~ 1300$ years. 


\subsection{Literature}

Ahmed F, Ahmed N, Pissarides C and Stiglitz J (2020) Why inequality could spread COVID-19. The Lancet Public Health. The Author(s). Published by Elsevier Ltd. This is an Open Access article under the CC BY 4.0 license 5(5): e240. Available at: http://dx.doi.org/10.1016/S2468-2667(20)30085-2: doi:10.1016/S2468-2667(20)30085-2.

Ahmed M, Anchukaitis KJ, Asrat A, Borgaonkar HP, Braida M, Buckley BM, et al. (2013) Continentalscale temperature variability during the past two millennia. Nature Geoscience 6(5): 339-346: doi:10.1038/ngeo1797.

Berglund BE (2003) Human impact and climate changes - Synchronous events and a causal link? Quaternary International 104: 7-12: doi:10.1016/s1040-6182(02)00144-1.

Bintanja R and Andry O (2017) Towards a rain-dominated Arctic. Nature Climate Change (March): 1-6. Available at: http://www.nature.com/doifinder/10.1038/nclimate3240: doi:10.1038/nclimate3240.

Bintanja R, Wiel K Van Der, Linden EC Van Der, Reusen J and Bogerd L (2020) Strong future increases in Arctic precipitation variability linked to poleward moisture transport. Science Advances (February): 1-7: doi:DOI: 10.1126/sciadv.aax6869.

Blok D, Schaepman-Strub G, Bartholomeus H, Heijmans MMPD, Maximov TC and Berendse F (2011) The response of Arctic vegetation to the summer climate: Relation between shrub cover, NDVI, surface albedo and temperature. Environmental Research Letters 6(3): doi:10.1088/1748-9326/6/3/035502.

Box JE, Colgan WT, Christensen TR, Schmidt NM, Lund M, Parmentier FJW, et al. (2019) Key indicators of Arctic climate change: 1971-2017. Environmental Research Letters. IOP Publishing 14(4): doi:10.1088/1748-9326/aafc1b.

Brown TA, Jones MK, Powell W and Allaby RG (2009) The complex origins of domesticated crops in the Fertile Crescent. Trends in Ecology and Evolution. Elsevier Ltd 24(2): 103-109. Available at: http:// dx.doi.org/10.1016/j.tree.2008.09.008: doi:10.1016/j.tree.2008.09.008.

Büntgen U, Urban O, Krusic PJ, Rybníček M, Kolář T, Kyncl T, et al. (2021) Recent European drought extremes beyond Common Era background variability. Nature Geoscience: doi:10.1038/s41561-02100698-0.

Chae Y, Kang SM, Jeong S, Kim B and Frierson DMW (2014) Arctic greening can cause earlier seasonality of Arctic amplification. 1-6: doi:10.1002/2014GL061841.Received.

Clayton S (2020) Climate anxiety: Psychological responses to climate change. Journal of Anxiety Disorders. Elsevier 74(March): 102263. Available at: https://doi.org/10.1016/j.janxdis.2020.102263: doi:10.1016/j.janxdis.2020.102263.

Cramwinckel MJ, Huber M, Kocken IJ, Agnini C, Bijl PK, Bohaty SM, et al. (2018) Synchronous tropical and polar temperature evolution in the Eocene letter. Nature 559(7714): 382-386: doi:10.1038/ s41586-018-0272-2.

D'Odorico P, Yoo JC and Jaeger S (2002) Changing seasons: An effect of the North Atlantic Oscillation? Journal of Climate 15(4): 435-445: doi:10.1175/1520-0442(2002)015<0435:CSAEOT>2.0.CO;2. 
de Boer HJ, Price CA, Wagner-Cremer F, Dekker SC, Franks PJ and Veneklaas EJ (2016) Optimal allocation of leaf epidermal area for gas exchange. New Phytologist 210(4): 1219-1228: doi:10.1111/ nph.13929.

Donders TH, Wagner-Cremer F and Visscher H (2008) Integration of proxy data and model scenarios for the mid-Holocene onset of modern ENSO variability. Quaternary Science Reviews 27(5-6): 571579: doi:10.1016/j.quascirev.2007.11.010.

Fauchald P, Park T, Tømmervik H, Myneni R and Hausner VH (2017) Arctic greening from warming promotes declines in caribou populations. Science advances 3(4): e1601365. Available at: http:// www.ncbi.nlm.nih.gov/pubmed/28508037\%0Ahttp://www.pubmedcentral.nih.gov/articlerender. fcgi?artid=PMC5406139: doi:10.1126/sciadv.1601365.

Finsinger W, Schoning K, Hicks S, Lücke A, Goslar T, Wagner-Cremer F, et al. (2013) Climate change during the past 1000 years: A high-temporal-resolution multiproxy record from a mire in northern Finland. Journal of Quaternary Science 28(2): 152-164: doi:10.1002/jqs.2598.

Fischer H, Meissner KJ, Mix AC, Abram NJ, Austermann J, Brovkin V, et al. (2018) Palaeoclimate constraints on the impact of $2{ }^{\circ} \mathrm{C}$ anthropogenic warming and beyond. Nature Geoscience 11(7): 474-485. Available at: http://www.nature.com/articles/s41561-018-0146-0: doi:10.1038/s41561-0180146-0.

Franzke C and Feldstein SB (2005) The continuum and dynamics of Northern Hemisphere teleconnection patterns. Journal of the Atmospheric Sciences 62(9): 3250-3267: doi:10.1175/ JAS3536.1.

Gouw-Bouman MTIJ, van Asch N, Engels S and Hoek WZ (2019) Late Holocene ecological shifts and chironomid-inferred summer temperature changes reconstructed from Lake Uddelermeer, the Netherlands. Palaeogeography, Palaeoclimatology, Palaeoecology. Elsevier 535(September): 109366. Available at: https://doi.org/10.1016/j.palaeo.2019.109366: doi:10.1016/j.palaeo.2019.109366.

Guay KC, Beck PS a, Berner LT, Goetz SJ, Baccini A and Buermann W (2014) Vegetation productivity patterns at high northern latitudes: A multi-sensor satellite data assessment. Global Change Biology 3147-3158: doi:10.1111/gcb.12647.

Habjørg A (1971) Effects of photoperiod and temperature on growth and development of three latitudinal and three altitudinal populations of Betula pubescens EHRH. Meldinger fra Norges landbrukshøgskole 44(26): 1-27.

Hanna E and Cropper TE (2017) North Atlantic Oscillation. Oxford Research Encyclopedia of Climate Science. Oxford University Press, 536-539. Available at: http://climatescience.oxfordre.com/ view/10.1093/acrefore/9780190228620.001.0001/acrefore-9780190228620-e-22: doi:10.1093/ acrefore/9780190228620.013.22.

Heiri O, Brooks SJ, Renssen H, Bedford A, Hazekamp M, Ilyashuk B, et al. (2014) Validation of climate model-inferred regional temperature change for late-glacial Europe. Nature communications 5(SEPTEMBER): 4914. Available at: http://www.ncbi.nlm.nih.gov/pubmed/25208610: doi:10.1038/ ncomms5914.

Hincke AJC, Broere T, Kürschner WM, Donders TH, Wagner-Cremer F, Wagner F, et al. (2016) MultiYear Leaf-Level Response to Sub-Ambient and Elevated Experimental CO2 in Betula nana. PLOS ONE 11(6): e0157400. Available at: http://dx.plos.org/10.1371/journal.pone.0157400: doi:10.1371/journal. 
pone.0157400.

Hoek WZ and Bohncke SJP (2002) Climatic and environmetnal events over the Last Termination. Netherlands Journal of Geosciences, 123-137.

Hollesen J, Buchwal A, Rachlewicz G, Hansen BU, Hansen MO, Stecher O, et al. (2015) Winter warming as an important co-driver for Betula nana growth in western Greenland during the past century. Global Change Biology 21(6): 2410-2423: doi:10.1111/gcb.12913.

Hurrell JW (2005) North atlantic oscillation. Encyclopedia of Earth Sciences Series: doi:10.1007/14020-3266-8_150.

Jones PD, Harpham C and Vinther BM (2014) Winter-responding proxy temperature reconstructions and the North Atlantic Oscillation. Journal of Geophysical Research: Atmospheres 119(11): 64976505: doi:10.1002/2013JD021272.Received.

Kelley CP, Mohtadi S, Cane MA, Seager R and Kushnir Y (2015) Climate change in the Fertile Crescent and implications of the recent Syrian drought. Proceedings of the National Academy of Sciences of the United States of America 112(11): 3241-3246: doi:10.1073/pnas.1421533112.

Kouwenberg L, Wagner R, Kürschner W and Visscher H (2005) Atmospheric CO2 fluctuations during the last millennium reconstructed by stomatal frequency analysis of Tsuga heterophylla needles. Geology 33(1): 33-36: doi:10.1130/G20941.1.

Kürschner WM (1997) The anatomical diversity of recent and fossil leaves of the durmast oak (Quercus petraea Lieblein/Q. pseudocastanea Goeppert) - Implications for their use as biosensors of palaeoatmospheric CO 2 levels. Review of Palaeobotany and Palynology 96(1-2): 1-30: doi:10.1016/ S0034-6667(96)00051-6.

Kürschner WM, van der Burgh J, Visscher H and Dilcher DL (1996) Oak leaves as biosensors of late neogene and early pleistocene paleoatmospheric CO2 concentrations. Marine Micropaleontology 27(1-4): 299-312: doi:10.1016/0377-8398(95)00067-4.

Li J, Fan K and Xu Z (2016) Links between the late wintertime North Atlantic Oscillation and springtime vegetation growth over Eurasia. Climate Dynamics. Springer Berlin Heidelberg 46(3-4): 987-1000: doi:10.1007/s00382-015-2627-9.

Liu Q, Piao S, Janssens IA, Fu Y, Peng S, Lian X, et al. (2018) Extension of the growing season increases vegetation exposure to frost. Nature Communications. Springer US 9(1): 426. Available at: http:// www.nature.com/articles/s41467-017-02690-y: doi:10.1038/s41467-017-02690-y.

Ljungqvist FC, Seim A and Huhtamaa H (2021a) Climate and society in European history. Wiley Interdisciplinary Reviews: Climate Change 12(2): 1-28: doi:10.1002/wcc.691.

Ljungqvist FC, Tegel W, Krusic PJ, Seim A, Gschwind FM, Haneca K, et al. (2018) Linking European building activity with plague history. Journal of Archaeological Science 98(June): 81-92: doi:10.1016/j. jas.2018.08.006.

Ljungqvist FC, Thejll P, Christiansen B, Seim A, Hartl C and Esper J (2021b) The significance of climate variability on early modern European grain prices. Cliometrica. Springer Berlin Heidelberg. Available at: https://doi.org/10.1007/s11698-021-00224-7: doi:10.1007/s11698-021-00224-7. 
Magnússon Rí, Limpens J, van Huissteden J, Kleijn D, Maximov TC, Rotbarth R, et al. (2020) Rapid vegetation succession and coupled permafrost dynamics in Arctic thaw ponds in the Siberian lowland tundra. Journal of Geophysical Research: Biogeosciences.

Mayewski PA, Rohling EE, Stager JC, Karlén W, Maasch KA, Meeker LD, et al. (2004) Holocene climate variability. Quaternary Research 62(3): 243-255: doi:10.1016/j.yqres.2004.07.001.

McMaster GS and Wilhelm WW (1997) Growing degree-days: one equation, two interpretations. Agricultural and Forest Meteorology 87(1): 291-300.

Menzel A, Sparks TH, Estrella N, Koch E, Aaasa A, Ahas R, et al. (2006) European phenological response to climate change matches the warming pattern. Global Change Biology 12(10): 1969-1976: doi:10.1111/j.1365-2486.2006.01193.x.

Miller P, Lanier W and Brandt S (2001) Using Growing Degree Days to Predict Plant Stages. Ag/ Extension Communications Coordinator, Communications Services, Montana State UniversityBozeman 9. Available at: www.msuextension.org.

Niedźwiedź T, Glaser R and Team. TBIA (2014) The Historical Time Frame (Past 1000 Years). 51-65: doi:10.1007/978-3-319-16006-1.

Niskanen AKJ, Niittynen P, Aalto J, Väre H and Luoto M (2019) Lost at high latitudes: Arctic and endemic plants under threat as climate warms. Diversity and Distributions (October 2018): 1-13: doi:10.1111/ddi.12889.

Raynolds M, Walker D, Verbyla D and Munger C (2013) Patterns of change within a tundra landscape: 22-year landsat NDVI trends in an area of the northern foothills of the brooks range, Alaska. Arctic, Antarctic, and Alpine Research 45(2): 249-260: doi:10.1657/1938-4246-45.2.249.

Reyes-Fox M, Steltzer H, Trlica MJ, McMaster GS, Andales AA, LeCain DR, et al. (2014) Elevated CO2 further lengthens growing season under warming conditions. Nature. Nature Publishing Group 510(7504): 259-262. Available at: http://www.ncbi.nlm.nih.gov/pubmed/24759322: doi:10.1038/ nature13207.

Ruddiman WF (1990) Changes in climate and biota on geologic time scales. Trends in Ecology and Evolution 5(9): 285-288: doi:10.1016/0169-5347(90)90082-O.

Salzer MW and Hughes MK (2007) Bristlecone pine tree rings and volcanic eruptions over the last 5000 yr. Quaternary Research 67(1): 57-68. Available at: http://linkinghub.elsevier.com/retrieve/pii/ S0033589406000998: doi:10.1016/j.yqres.2006.07.004.

Shen M, Tang Y, Chen J, Yang X, Wang C, Cui X, et al. (2014) Earlier-season vegetation has greater temperature sensitivity of spring phenology in northern hemisphere. PLoS ONE 9(2): doi:10.1371/ journal.pone.0088178.

Sluijs A, Schouten S, Donders TH, Schoon PL, Röhl U, Reichart GJ, et al. (2009) Warm and wet conditions in the Arctic region during Eocene Thermal Maximum 2. Nature Geoscience. Nature Publishing Group 2(11): 777-780. Available at: http://dx.doi.org/10.1038/ngeo668: doi:10.1038/ngeo668.

Steffen W, Richardson K, Rockström J, Schellnhuber HJ, Dube OP, Dutreuil S, et al. (2020) The emergence and evolution of Earth System Science. Nature Reviews Earth \& Environment 1(1): 54-63: doi:10.1038/s43017-019-0005-6. 
Steinthorsdottir M, Wagner-cremer F and Steinthorsdottir M (2019) Hot summers ahead? Multidecadal spring season warming precedes sudden summer temperature rise in pre-anthropogenic climate change summer temperature rise in pre-anthropogenic climate change. GFF. Taylor \& Francis 00(00): 1-6. Available at: https://doi.org/10.1080/11035897.2019.1655791: doi:10.1080/11035897.20 19.1655791.

Thomson MJ and MacDonald GM (2020) Climate and growing season variability impacted the intensity and distribution of Fremont maize farmers during and after the Medieval Climate Anomaly based on a statistically downscaled climate model. Environmental Research Letters 15(10): doi:10.1088/17489326/aba57e.

Trouet V, Esper J, Graham NE, Baker A, Scourse JD and Frank DC (2009) Persistent positive north atlantic oscillation mode dominated the medieval climate anomaly. Science 324(5923): 78-80: doi:10.1126/ science.1166349.

Trouet V and Van Oldenborgh GJ (2013) KNMI Climate Explorer: A Web-Based Research Tool for HighResolution Paleoclimatology. Tree-Ring Research 69(1): 3-13. Available at: http://www.bioone.org/ doi/abs/10.3959/1536-1098-69.1.3: doi:10.3959/1536-1098-69.1.3.

Van Der Burgh J, Visscher H, Dilcher DL and Kürschner WM (1993) Paleoatmospheric signatures in neogene fossil leaves. Science (New York, N.Y.) 260(5115): 1788-90. Available at: http://www.ncbi. nlm.nih.gov/pubmed/17793657: doi:10.1126/science.260.5115.1788.

van Hoof TB, Bunnik FPM, Waucomont JGM, Kürschner WM and Visscher H (2006) Forest regrowth on medieval farmland after the Black Death pandemic-Implications for atmospheric CO2 levels. Palaeogeography, Palaeoclimatology, Palaeoecology 237(2-4): 396-409: doi:10.1016/j. palaeo.2005.12.013

Vinther BM, Jones PD, Briffa KR, Clausen HB, Andersen KK, Dahl-Jensen D, et al. (2010) Climatic signals in multiple highly resolved stable isotope records from Greenland. Quaternary Science Reviews 29(34): 522-538: doi:10.1016/j.quascirev.2009.11.002.

Visbeck MH, Hurrell JW, Polvani L and Cullen HM (2001) The North Atlantic Oscillation: past, present, and future. Proceedings of the National Academy of Sciences of the United States of America 98: 12876-12877. Available at: http://www.pnas.org/content/98/23/12876.full.pdf: doi:10.1073/ pnas.231391598.

Visscher H, Looy C V., Collinson ME, Brinkhuis H, Van Konijnenburg-Van Cittert JHA, Kürschner WM, et al. (2004) Environmental mutagenesis during the end-Permian ecological crisis. Proceedings of the National Academy of Sciences of the United States of America 101(35): 12952-12956: doi:10.1073/ pnas.0404472101.

Wagner-Cremer F, Donders TH and Visscher H (2010a) Drought stress signals in modern and subfossil Quercus laurifolia (Fagaceae) leaves reflect winter precipitation in southern Florida tied to El NiñoSouthern Oscillation activity. American Journal of Botany 97(5): 753-759: doi:10.3732/ajb.0900196.

Wagner-Cremer F, Finsinger W and Moberg A (2010b) Tracing growing degree-day changes in the cuticle morphology of Betula nana leaves: A new micro-phenological palaeo-proxy. Journal of Quaternary Science 25(6): 1008-1017: doi:10.1002/jqs.1388.

Wagner F, Aaby B and Visscher H (2002) Rapid atmospheric CO2 changes associated with the 8,200-years-B.P. cooling event. Proceedings of the National Academy of Sciences of the United States 
Chapter 1

of America 99(19): 12011-12014: doi:10.1073/pnas.182420699.

Wagner F, Neuvonen S, Kürschner WM and Visscher H (2000) The influence of hybridization on epidermal properties of birch species and the consequences for palaeoclimatic interpretations. Plant Ecology 148(1): 61-69: doi:10.1023/A:1009801614786.

Wu CJ, Usoskin IG, Krivova N, Kovaltsov GA, Baroni M, Bard E, et al. (2018) Astrophysics Solar activity over nine millennia : A consistent multi-proxy reconstruction to the. 93: 1-13.

Zhang DD, Lee HF, Wang C, Li B, Pei Q, Zhang J, et al. (2011) The causality analysis of climate change and large-scale human crisis. Proceedings of the National Academy of Sciences of the United States of America 108(42): 17296-17301: doi:10.1073/pnas.1104268108. 


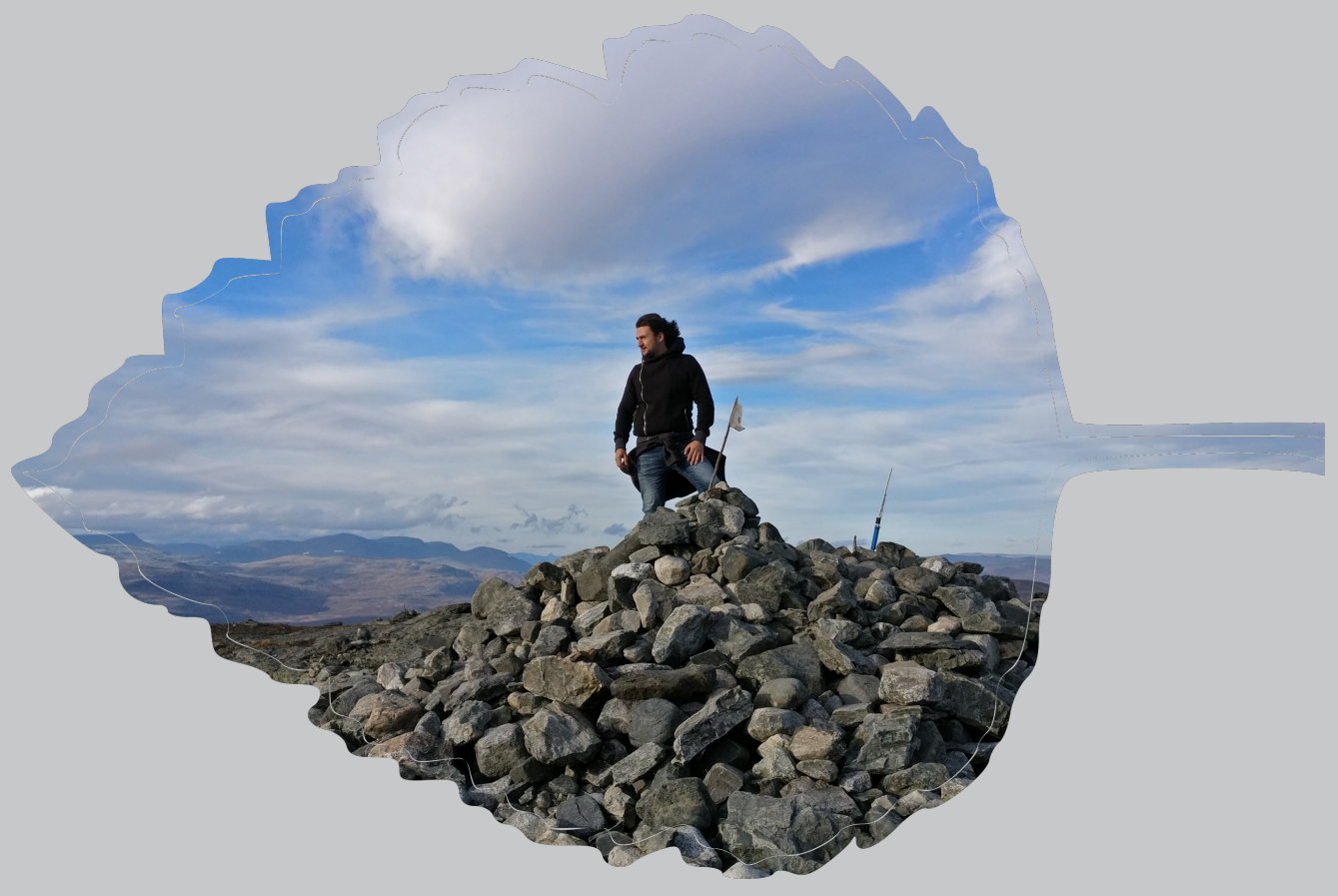




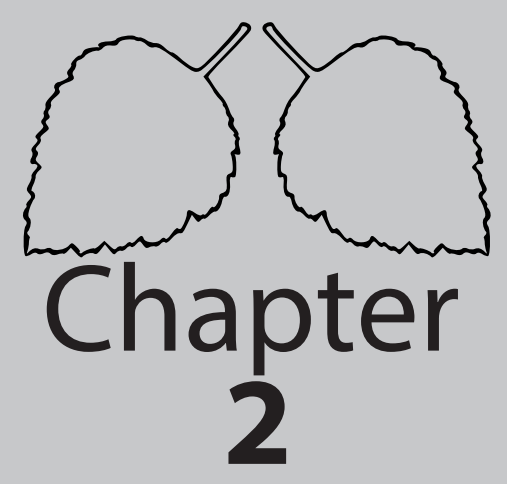




\title{
A growing degree day inference model based on mountain birch leaf cuticle analysis over a latitudinal gradient in Fennoscandia.
}

\author{
Fabian E.Z. Ercan ${ }^{1}$ | Hugo J. de Boer ${ }^{2}$ | Friederike Wagner-Cremer ${ }^{1}$ \\ 1 Palaeoecology, Physical Geography, Utrecht University, Utrecht, The Netherlands \\ ${ }^{2}$ Copernicus Institute of Sustainable Development, Department of Environmental Sciences, Utrecht \\ University, Utrecht, The Netherlands
}

As published in The Holocene, 2020

\begin{abstract}
2.1 Abstract
Cuticle analysis performed on fossil Betula nana (L.) leaves provides a strong proxy to reconstruct past growing season thermal properties expressed as growing degree days (GDDs). This proxy is so far available for the dwarf birch only and therewith restricted to regions or past periods of subarctic climatic conditions. In the present study we analysed modern leaf samples of mountain birch (B. pubescens spp. czerepanovii (N. I. Orlova) Hämet-Ahti) which has a wider temperature range than the dwarf birch B. nana. The strong latitudinal climate gradient over Fennoscandia provides a unique opportunity to track growing season temperature imprints in the epidermis cell morphology of modern mountain birch. We quantified the GDD5 dependent epidermal cell expansion, expressed as the Undulation Index (UI), over a $10^{\circ}$ latitudinal transect translating to a range from $\sim 1500$ to $\sim 600^{\circ} \mathrm{C} \mathrm{GDD}_{5}$ in 2016. Or results indicate that also in mountain birch the $\mathrm{UI}$ is positively correlated to $\mathrm{GDD}_{5}$ and moreover largely independent of regional habitat conditions such as day light length and precipitation. These results imply that, in addition to the earlier studied (sub-) arctic dwarf birch, also the closely related mountain birch can be utilized in GDDs reconstructions. The abundant presence of fossil mountain birch leaves in sediments from warmer than (sub-)arctic paleoclimates enables the reconstruction of growing season climate dynamics over past phases of climate change overcoming earlier restrictions of the proxy related to spatial and temporal species occurrence as well as local light regimes.
\end{abstract}




\subsection{Introduction}

Paleobotanical proxies based on cuticle properties are increasingly implemented to reconstruct environmental and climatic changes by quantifying leaf morphological adaptations in response to environmental changes. The variety of proxies available to date enable atmospheric $\mathrm{CO}_{2}$ reconstructions (McElwain and Steinthorsdottir, 2017; Royer, 2001; Wagner et al., 2004), estimates of transpiration changes (Bodin et al., 2013; de Boer et al., 2011; Franks and Beerling, 2009; Lammertsma et al., 2011), drought stress signals (Wagner et al., 2007) and volcanic $\mathrm{SO}_{2}$ pollution (Steinthorsdottir et al., 2018). Microphenological studies have further demonstrated that also growing season thermal conditions result in distinct imprints in the leaf epidermal cell morphology (Wagner-Cremer et al., 2010).

Microphenological proxies for growing season dynamics through time are of interest since ongoing global warming causes a significant lengthening of the growing season in large parts of the Northern Hemisphere which alters spring phenology of woody plants (Flynn and Wolkovich, 2018; Polgar and Primack, 2011; Zohner and Renner, 2014). The physiological response of plants in return has the potential to alter the physical and biological properties of large vegetated land areas influencing local and regional climatic conditions though albedo and transpiration feedbacks (Bonan, 2008; Lian et al., 2018; Piao et al., 2017).

In this context, growing season climate reconstructions provide a powerful tool for determining seasonality dynamics during natural climate change on various spatiotemporal scales (Finsinger et al., 2013; Wagner-Cremer and Lotter, 2011). The leaf cuticle analysis based proxy quantifying the growing season thermal properties, relies on the maturation stage of leaf epidermal cells reached under the cumulative growing degree days (GDD) during the annual growth period (Wagner-Cremer et al., 2010). The leaf epidermal cell expansion follows a ontogenetic succession where cell size and cell wall sinuosity increase during the leaf maturation period (Kürschner et al., 1996; Wagner et al., 2007; Wagner-Cremer et al., 2010). The maturation stage of the epidermal cells is expressed as the undulation index (UI) which quantifies the degree of cell wall sinuosity over cell area (Kürschner et al., 1996). This proxy has originally been introduced to identify light intensity related leaf morphotypes in closed canopy species such as oak (Kürschner et al., 1996). In open canopy trees and shrubs such as Betula, however, the undulation occurring in epidermal cells is strongly related to the duration and temperature available to plants during the growth period (Wagner-Cremer et al., 2010). 
A distinct correlation between the $\mathrm{UI}$ of the (sub-)arctic dwarf birch B. nana and $\mathrm{GDD}_{5}$ (the growing season cumulative sum of degree Celsius above $5^{\circ} \mathrm{C}$ ) has first been established through continuous leave monitoring ongoing since 1996 at the Subarctic Research Station site in Kevo, northern Finland (Wagner-Cremer et al., 2010). The robustness of the available UI inference model as GDD5 proxy has subsequently been tested by comparison of UI values from fossil $B$. nana leaf cuticles preserved in Scandinavian peats deposits with historical GDD5 records (Finsinger et al., 2013; Wagner-Cremer et al., 2010). A first application to late glacial B. nana cuticles has further shown the applicability to Quaternary periods of rapid climate change (Wagner-Cremer and Lotter, 2011).

Although the potential value of the UI as a GDD5 proxy to support spatio-temporal analysis of seasonality changes has been demonstrated, the proxy is currently tested only for the (sub-) arctic dwarf birch. In order to apply this proxy on a broader spatial and temporal scale, additional modern species with more southern geographical ranges are needed to overcome the limits of the GDD 5 inference model for $B$. nana with its relatively narrow temperature range.

Moreover, potential sources of reconstruction uncertainties have to be evaluated. A point of discussion is thereby the influence of photoperiod on leaf phenology under changing temperatures (Flynn and Wolkovich, 2018; Körner and Basler, 2010; Zohner et al., 2016).

This study focusses on the Scandinavian mountain birch (B. pubescens spp. czerepanovii (N. I. Orlova) Hämet-Ahti), which groups the introgressive hybrids between the downy birch (B. pubescens Ehrh.) and the dwarf birch (B. nana L.) (Vaarama and Valanne, 1973; Wagner et al., 2000). The mountain birch contributes large proportions to the Fennoscandian broadleaved forests and occurs over the climatic gradient from cold-temperate to sub-arctic conditions. Over this geographic range the cold adapted dwarf birch is successively replaced by the thermophilous mountain birch, therewith providing an opportunity to extend $\mathrm{GDD}_{5}$ and photoperiod ranges to more warmer climates in lower latitudes. Cuticle analysis of the different birch species and hybrids has already revealed distinct and specific morphological characteristics of mountain birch and dwarf birch that allows to distinguish mountain birch from dwarf birch in fossil leaf samples (Wagner et al., 2000). In this study we therefore aim to expand and validate the UI proxy for growing season thermal properties by quantifying the sensitivity of mountain birch to the GDD5 range occurring over a $10^{\circ}$ latitudinal gradient in Scandinavia. 


\subsection{Materials and Methods}

\subsubsection{Leaf Sampling}

The leaf sampling campaign was carried out in 2016 at the end of the growing season (24 - 30 September), when trees showed autumn colours indicating leaf senescence. We sampled 20 randomly selected mountain birch leaves per site at 28 locations in Finland and northern Norway (Figure 2.2), with a spacing of approximately $100 \mathrm{~km}$ between sites.

\subsubsection{Microscopic Analysis}

From 26 locations three to five leaves were analysed. Sections of $0.5 \times 0.5 \mathrm{~cm}$ from individual leaves were bleached in sodium hypochlorite $(<5 \%)$ at room temperature for 12 - 24 hours. The lower cuticle was subsequently removed and stained with safranin. Permanent microscopic slides were made using glycerine jelly. Five digital photographs of each cuticle were taken using a Leica Quantimet 500C/500+ microscope and AnalySIS image analysis software (AnalySIS auto 5.1) at $1000 \times$ magnification. Analysis of epidermal and stomatal cell properties was performed using ImageJ 1.52a. Two representative cuticle images with low and high UI are shown in figure $\mathbf{2 . 1}$.

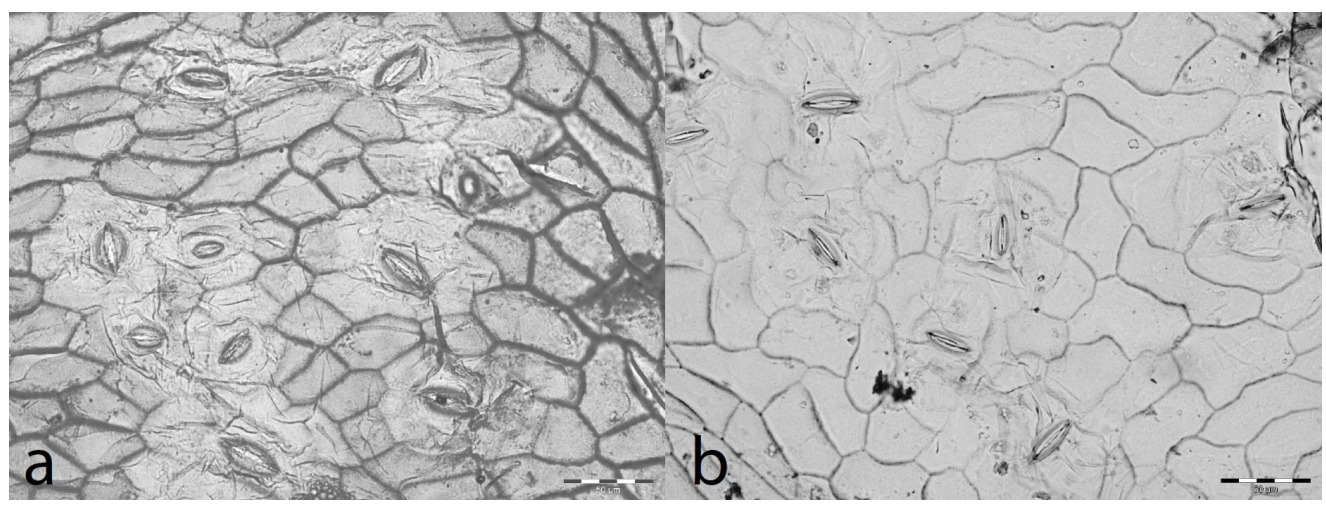

Figure 2.1: Representative images of mountain birch cuticles grown under 776 GDD5 (a) and 1493 $\mathrm{GDD}_{5}(\mathbf{b})$, showing stomata bearing alveole areas and epidermal cells with low and high cell wall undulation, respectively. Scale bar is $50 \mu \mathrm{m}$. 
To estimate the mean epidermal cell area $\left(C A ;\left[\mu m^{2}\right]\right)$ and epidermal cell circumference (CC; $[\mu \mathrm{m}]) 30$ random pavement cells per sample were analysed, avoiding cells over venation and leaf margins. From CA and CC, the undulation index (Ul; dimensionless, equation 2.1) of the epidermal cell wall was calculated following Kürschner (1997).

$$
U I[\text { dimensionless }]=\frac{C C}{2 \pi \cdot \sqrt{C A / \pi}}
$$

\section{[Equation 2.1]}

\subsubsection{Meteorological data}

To compare cuticle analysis results to meteorological data, the measured daily average temperature and precipitation data of the weather station nearest to each individual sampling site was extracted from the KNMI Explorer database (van Oldenborgh et al., 2009).

$\mathrm{GDD}_{5}$ was calculated (Equation 2.2) from daily temperatures recorded throughout the growing season. GDD covers the growing potential for vegetation in a given year and is expressed by the cumulative sum of degrees Celsius above a determined base temperature (McMaster and Wilhelm, 1997; Weijers et al., 2013).

\section{[Equation 2.2]}

$$
G D D_{X}=\sum_{i=1}^{274}\left(T_{i}-X\right), \quad T_{i} \geq X
$$

where $\mathrm{Ti}$ is the daily mean temperature for day $\mathrm{i}$ and $\mathrm{X}$ is the selected threshold temperature in degrees Celsius. For Ti, the daily mean temperature from each station was used. For the latitudinal range covered in this study, $5^{\circ} \mathrm{C}$ is the commonly used threshold temperature for plant growth and was taken as threshold temperature $X$ , resulting in GDD 5 (Carter, 1998). The sum of GDD 5 was calculated from January 1st, 2016 to September 30th, 2016. May through September (MJJAS) temperature and precipitation data were used to calculate average spring and summer conditions. Average winter temperature and precipitation were calculated from November, December 2015 as well as January, February, and March 2016 (NDJFM). We note 
that the long summer and winter definitions were necessary to cover the growing season of the southernmost sample locations. Average precipitation and the total precipitation sum were calculated as October 1st, 2015 until September 30th, 2016 , representing the total amount of precipitation since shedding of the leaves in the previous season to senescence of the current leaf sample set. Photoperiod (PP) was defined as the cumulative sunlight hours at the latitude of each sample location between March and September.

\subsubsection{Spatial analysis}

To visualize spatial variability in $\mathrm{GDD}_{5}$ and $\mathrm{UI}$, inverse distance weighted interpolation (Shepard, 1964) was performed using the "idw()" function in the gstat package (Gräler et al., 2016) in R version 3.5.2 (R Core Team, 2019). A maximum search radius of $100 \mathrm{~km}$ was set based on sampling distance, and inverse distance weighting power was set to 2 . This resulted in a root-mean-square deviation of 0.02 for UI and 95.09 for GDD5 (as determined from leave-one-out cross validation). For management and visualization of spatial data in R, the rgdal (Bivand et al., 2018), raster (Hijmans, 2018) and sp (Bivand et al., 2013; Pebesma and Bivand, 2005) packages were used. Country basemaps were retrieved from the ggplot2 package (Wickham, 2016).

\subsubsection{GDD 5 Inference model}

Linear least-square regression was used to relate measured UI values to known $\mathrm{GDD}_{5}$ across all sampling localities. For the prediction of past growing degree days (GDDsfossil) from Ul obtained from fossil leaf material (Ulfossil) values, it is necessary to inverse the original least-squares regression function [UI] $=a\left[G D D_{5}\right]+b$. The inverse of the fit results in [GDDsfossil]=[Ulfossil](1/a)-(b/a) and minimizes the error towards the original modern y-variable (UI), with x-variable (GDD5) as fixed measurement. A Monte-Carlo simulation (1000 times repetition) based on the mean UI values for each locality was used to test the reliability of the inference model, each time with a random division of the dataset in a reference and a test half, generating averages and uncertainty ranges in the slope (a) and intercept (b) for the inference model function.

\subsubsection{Independent test data}

To additionally test the predictive capacity of the inference model, GDD5 values were inferred from an independent data set of UI values measured on mountain 
birch leaves collected in 1997 at several Finnish sites between $62^{\circ} \mathrm{N}$ to $70^{\circ} \mathrm{N}$ (Table 2.1) including samples published in Wagner et al. (2000). The leave material has been sampled and analysed applying the same protocol as for the samples collected in 2016. For the five Finnish localities instrumental GDD5 data for 1997 (van Oldenborgh et al., 2009) are available to which the inferred GDD5 values are compared.

Table 2.1: Test samples of mountain birch leaves collected in 1997. Ul: undulation index; GDD: growing degree days.

\begin{tabular}{|l|l|l|l|}
\hline Locality & Latitude $^{\circ} \mathbf{N}$ & UI & GDD $_{5} \mathbf{1 9 9 7}$ \\
\hline Mekrijärvi, Finland & 62.4 & $1.24 \pm 0.02$ & 1498 \\
\hline Oulu, Finland & 65.0 & $1.18 \pm 0.03$ & 1195 \\
\hline Peera, Finland & 69.0 & $1.17 \pm 0.02$ & 760 \\
\hline Kevo 2, Finland & 69.5 & $1.17 \pm 0.02$ & 765 \\
\hline Kevo 1, Finland & 69.9 & $1.15 \pm 0.02$ & 745 \\
\hline
\end{tabular}

\subsection{Results}

An inverse distance weighted interpolation of the data has been used to visualize the spatial distribution of GDD5 and UI values, respectively (Figure 2.2). The GDD5 data from the meteorological observations range from $1493 \mathrm{GDD}_{5}$ to $578 \mathrm{GDD}_{5}$ over the latitudinal gradient from $60.7 \mathrm{~N}-69.9 \mathrm{~N}$ (Figure 2.2a, b). UI values range from 1.12 - 1.27 over the same latitudinal gradient (Figure $\mathbf{2} \mathbf{c}, \mathbf{d}$ ). GDD5 and UI thereby show strong linear negative relations to latitude, $R^{2}=0.88$ and $R^{2}=0.69$, respectively.

The UI of the 2016 latitudinal transect has been tested against latitude, winter temperature, winter precipitation, summer temperature, summer precipitation, GGD5 and photoperiod of the growing season (Table 2).

\subsubsection{GDD 5 inference model}

We developed our $\mathrm{GDD}_{5}$ inference model based on site-averaged UI values obtained from the 2016 transect together with meteorological observations of $\mathrm{GDD}_{5}$ along this transect (Figure 2.3a). Using inverse regression, we obtained the linear function: [GGD5]=7744.8[UI] $-8086.8\left(R^{2}=0.77, p<0.001\right)$. The $95 \%$ confidence intervals of the slope and intercept of the GGD5 inference model are $6178.4-1017.1$, and $-1089.8--6244.2$, respectively. 
To test the predictive skills and accuracy of the inferrence model, independend UI data from a transect with a similar latidudinal range $\left(62.4^{\circ} \mathrm{N}-69.9^{\circ} \mathrm{N}\right)$ collected in 1997 with known GDDs at growth locality have been run trough the inference model (Figure 2.3b). There is some minor offset in slope and intercept beween hypothetical controll line $(y=x)$ and the linear model $(y=1.1219 x-207.7)$ fitted trough the predicted values and their corrosponding observed values the predicting value of the inferrence model is high $\left(R^{2}=0.86, p=0.02\right)$.
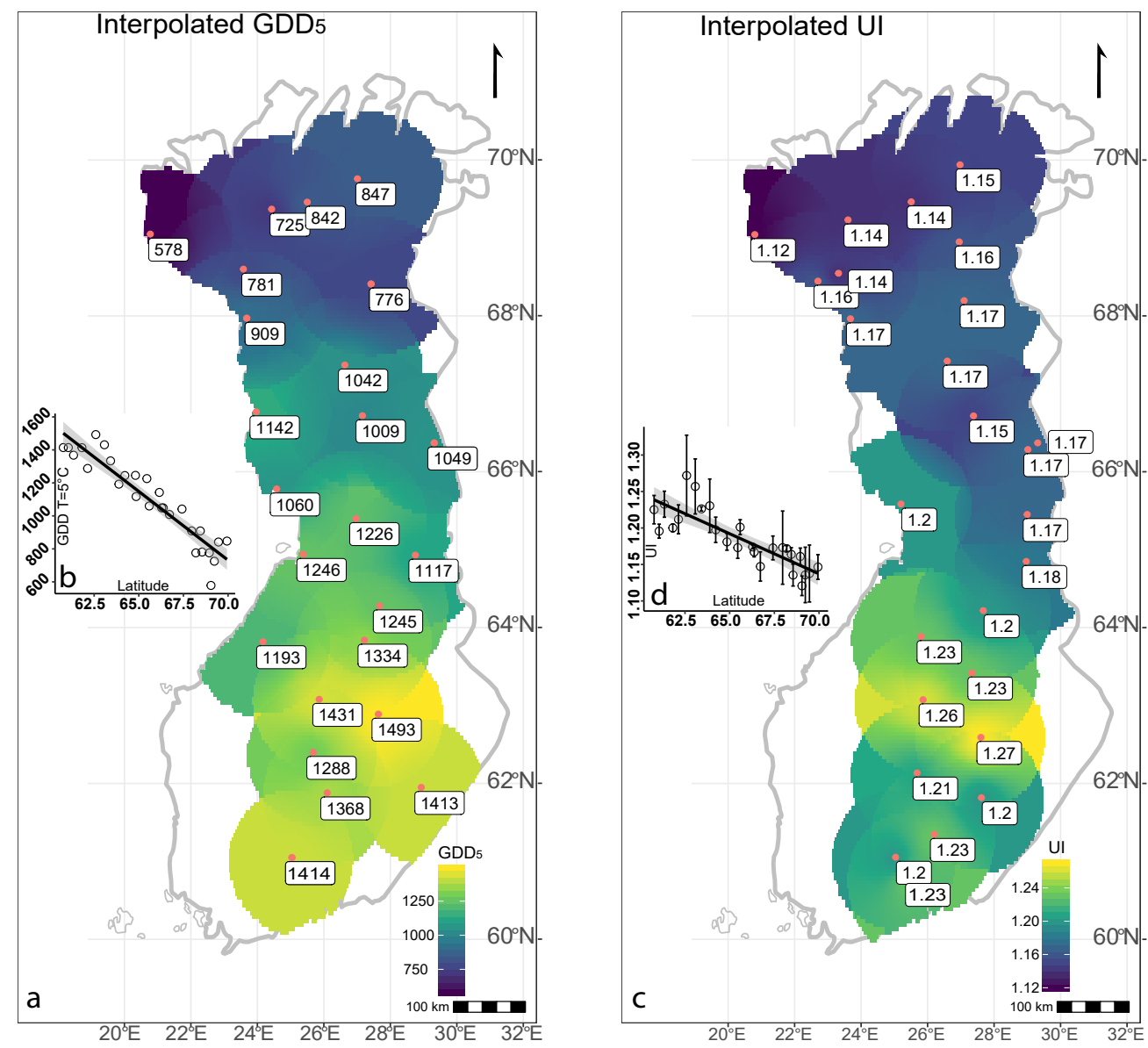

Figure 2.2: (a) Meteorological station locations $(n=28)$ and their measured GDD5 values, with inverse distance weighted interpolation gradient. (b) Linear relation between Latitude and GDD5. (c) Sample locations and the measured mountain birch UI values $(n=26)$ with inverse distance weighted interpolation gradient. (d) Linear relation between Latitude and UI with error bars indicating the naturally occurring variance in UI. 


\section{Chapter 2}

Table 2.2: Epidermal characteristics and meteorological data (correlation coefficients $(R$ value) and coefficient of determination ( $R^{2}$ value) are given in parenthesis). UI: undulation index; NDJFM: November, December 2015 and January, February and March 2016; MJJAS: May through September; GDD: growing degree days; PP: photoperiod; n.s.: not significant. ${ }^{* *} p<0.001 .{ }^{*} p<0.1$

\begin{tabular}{|l|l|l|l|l|l|l|l|l|}
\hline & UI & Latitude & $\begin{array}{l}\text { Temp } \\
\text { NDJFM }\end{array}$ & $\begin{array}{l}\text { Precip } \\
\text { NDJFM }\end{array}$ & $\begin{array}{l}\text { Temp } \\
\text { MJJAS }\end{array}$ & $\begin{array}{l}\text { Precip } \\
\text { MJJAS }\end{array}$ & GDD5 & $\begin{array}{l}\text { PP } \\
\text { MAMJJAS }\end{array}$ \\
\hline UI & $\mathrm{X}$ & $\begin{array}{l}-0.83 \\
(0.69)^{* * *}\end{array}$ & $\begin{array}{l}0.86 \\
(0.74)^{* * *}\end{array}$ & $\begin{array}{l}0.78 \\
(0.61)^{* * *}\end{array}$ & $\begin{array}{l}0.79 \\
(0.62)^{* * * *}\end{array}$ & n.s. & $\begin{array}{l}0.88 \\
(0.77)^{* * *}\end{array}$ & $\begin{array}{l}-0.85 \\
(0.72)^{* * *}\end{array}$ \\
\hline Latitude & $\begin{array}{l}-0.83 \\
(0.69)^{* * *}\end{array}$ & $\mathrm{X}$ & $\begin{array}{l}-0.97 \\
(0.94)^{* * *}\end{array}$ & $\begin{array}{l}-0.89 \\
(0.79)^{* * *}\end{array}$ & $\begin{array}{l}-0.97 \\
(0.94)^{* * * *}\end{array}$ & $\begin{array}{l}-0.89 \\
(0.79)^{* * * *}\end{array}$ & $\begin{array}{l}-0.94 \\
(0.88)^{* * *}\end{array}$ & $1^{* * *}$ \\
\hline GDD5 & $\begin{array}{l}0.88 \\
(0.77)^{* * *}\end{array}$ & $\begin{array}{l}-0.94 \\
(0.88)^{* * *}\end{array}$ & $\begin{array}{l}0.92 \\
(0.85)^{* * *}\end{array}$ & $\begin{array}{l}0.82 \\
(0.67)^{* * *}\end{array}$ & $\begin{array}{l}0.89 \\
(0.79)^{* * *}\end{array}$ & $\begin{array}{l}-0.36 \\
(0.13)^{*}\end{array}$ & $\mathrm{X}$ & $\begin{array}{l}-0.95 \\
(0.90)^{* * *}\end{array}$ \\
\hline
\end{tabular}

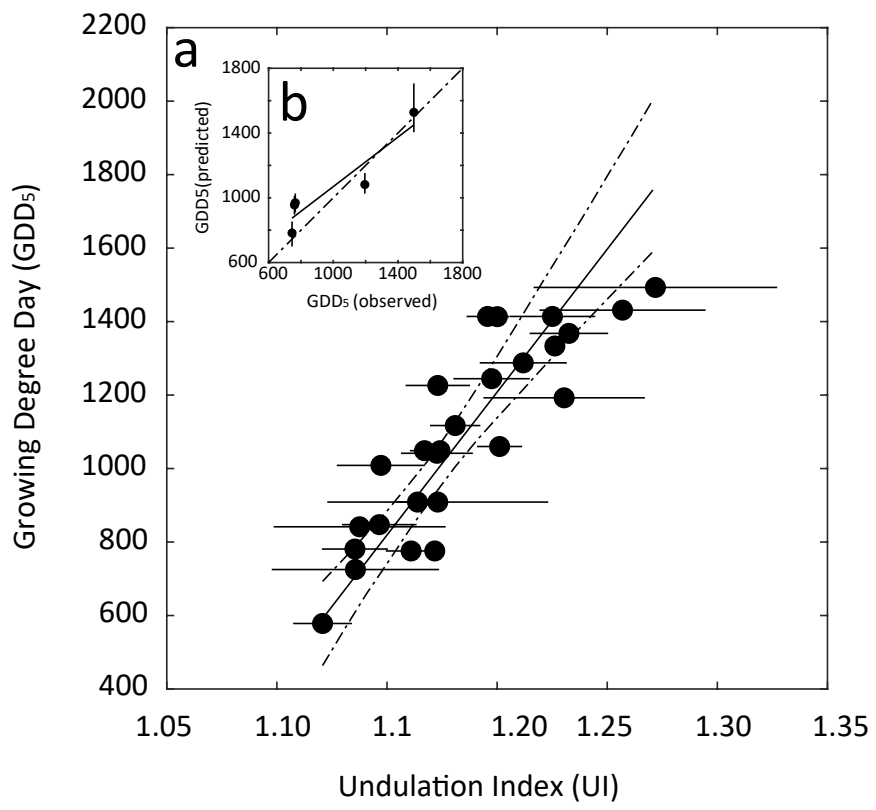

Figure 2.3: (a) Inference model fit showing the relation between GDD5 and UI of mountain birch obtained from the 2016 transect. Round markers indicate UI sample means, horizontal error bars indicate one standard deviation around the sample mean. The solid and dashed lines show the mean model fit with 95\% confidence intervals. (b) Independent inference model test based on leaves collected in 1997 at five localities in Scandinavia. Round markers indicate observed versus predicted GDD5 inferred using the 2016 inference model. Vertical error bars indicate $95 \%$ confidence intervals around the predicted GGD5. The solid line is the linear regression $\left(R^{2}=0.86, p=0.24\right)$, the dashed line represents a hypothetical 1:1 relation between predicted and observed GDD 5 values. 


\subsection{Discussion}

\subsubsection{UI sensitivity to GDD5}

Local GDD 5 values explain $77 \%$ of the UI variability in a highly significant linear relation over the range from 578 to $1493 \mathrm{GDD}_{5}$ and thus corroborates the proposed concept that growing season thermal properties produce a strong, detectable imprint in the leaf morphology in open canopy species (WagnerCremer et al., 2010). The data thereby show that this adjustment in epidermal cell morphology does not only occur in the subarctic dwarf birch B. nana, but is also present in mountain birch. The mountain birch is closely related to the dwarf birch and originates from hybridization between B. nana and B. pubescens (Vaarama and Valanne, 1973; Wagner et al., 2000) under current climatic conditions in the northern high latitudes. Fossil hybrid forms are difficult to recognize, but are likely to have occurred under past climate changes, too (Wagner et al., 2000). Testing of cuticle characteristics in B. nana, B. pubescens and various mountain birch hybrids grown in the treeline arboretum at Kevo subarctic research station (Utjoki, Finland) has shown, however, that the mountain birch varieties can be treated as a single group since no significant differences in UI or other cuticle characteristics has been found (Wagner et al., 2000). The separation between mountain birch and B. nana in fossil, fragmented material relatively easy through either leaf margin analysis or, if marginal parts are not available via determination of the stomatal length which is significantly lower in B. nana than in the mountain birch group (Wagner et al., 2000).

The validity of the mountain birch inference model is supported by an independent sample set collected in 1997 from localities with instrumental GDD5 data. The response rate of the $\mathrm{UI}$ in mountain birch to $\mathrm{GDD}_{5}$ is moreover highly comparable to the relation determined for $B$. nana, with UI changes of approximately $0.02-0.03$ (UI) per $100^{\circ} \mathrm{C} \mathrm{GDD}_{5}$ based on the currently available GDD5 ranges of the individual inference models.

\subsubsection{Effects of photoperiod and precipitation}

Our results also revealed a significant negative correlation between photoperiod and UI. Photoperiod is a globally unidirectional parameter associated to latitude which determines the amount of daylight available during the growth period of the plants which can be especially critical at the start of the season. The mountain birch is a typical pioneer species that occurs in the early vegetation succession. 
Phenological observations of pioneer species such as birch, hazel or poplar show that onset of leaf growth is insensitive to photoperiod in spring and that budburst and leaf growth are thus predominantly regulated by temperature (Körner and Basler, 2010; Polgar and Primack, 2011). Earlier studies on the effects of photoperiod on $B$. pubescens show that in experimental setups increased photoperiod under set temperature leads increasing leaf size and numbers (Habjørg, 1971). This photoperiodic response however, is suppressed when plants are exposed to low temperatures overruling the positive effect of prolonged day-light availability (Habjørg, 1971). These findings support our hypothesis that the UI in mountain birch is not directly linked to day-light length, but that the determined correlation rather reflects a false signal resulting from the co-occurring, but unrelated latitudinal changes of GDD5 and photoperiod.

A strong latitudinal precipitation gradient occurs over Scandinavia, where southern and eastern Finland receive nearly twice as much precipitation as the northern region of Lapland. Our data show high correlation values for the UI and winter precipitation, but no correlation of UI with summer precipitation. Winter precipitation of the studied year clearly follows the general latitudinal precipitation gradient as evident from the high negative correlation between these two variables. The winter precipitation is predominantly received as snow and thus does not directly affect leaf growth after snowmelt. The lack of correlation with the summer precipitation on the contrary corroborates earlier findings from a single-site study from Kevo, Lapland, where continuous time series analysis over the period from 1975 to 2008 did not reveal any significant imprint of May-September precipitation in the UI of B. nana (Wagner-Cremer et al., 2010). Nonetheless, water deficit has the potential to reduce epidermal cell expansion (Wagner-Cremer et al., 2010) and throughout individual growing seasons may well have a growth restricting effect, an aspect that needs careful consideration and additional testing.

Our results support the GDD $\mathrm{G}_{5}$ inference model for mountain birch as a valuable addition to the proxy so far restricted to B. nana. By adding mountain birch, the temperature range over which the proxy can be applied is expanded and now covers growing season temperature regimes characteristic for boreal forest biomes rather than (sub-)arctic conditions only. Spring season reconstructions based on cuticle analysis thus become possible also for sites and localities where the fossil leaf assemblages either include climatic warming phases with vegetation successions or for leaf bearing sequences in geographical regions outside the climatic prerequisites of the (sub-)arctic dwarf birch. 


\subsection{Acknowledgements}

The authors thank Heather Mariash for fieldwork guidance. Rúna Magnússon is thanked for cartographic assistance. Kevo Subarctic Research Station, Utsjoki, Finland is thanked for their assistance.

\subsection{Literature}

Bivand R, Keitt T and Rowlingson B (2018) rgdal: Bindings for the "Geospatial" Data Abstraction Library. . Available at: https://cran.r-project.org/package=rgdal.

Bivand RS, Pebesma E and Gomez-Rubio V (2013) Applied spatial data analysis with R. New York. Available at: http://www.asdar-book.org/.

Bodin PE, Gagen M, McCarroll D, Loader NJ, Jalkanen R, Robertson I, et al. (2013) Comparing the performance of different stomatal conductance models using modelled and measured plant carbon isotope ratios ( $\delta 13 C)$ : Implications for assessing physiological forcing. Global Change Biology 19(6): 1709-1719: doi:10.1111/gcb.12192.

Bonan GB (2008) Forests and climate change: forcings, feedbacks, and the climate benefits of forests. Science 320(5882): 1444-1449. Available at: http://www.ncbi.nlm.nih.gov/pubmed/18556546: doi:10.1126/science.1155121.

Carter TR (1998) Changes in the thermal growing season in Nordic countries during the past century and prospects for the future. Agricultural and Food Science 7(2): 161-179: doi:10.23986/afsci.72857.

de Boer HJ, Lammertsma El, Wagner-Cremer F, Dilcher DL, Wassen MJ and Dekker SC (2011) Reply to Miglietta et al.: Maximal transpiration controlled by plants. Proceedings of the National Academy of Sciences 108(28): E276-E276. Available at: http://www.pnas.org/cgi/doi/10.1073/pnas.1107648108: doi:10.1073/pnas.1107648108.

Finsinger W, Schoning K, Hicks S, Lücke A, Goslar T, Wagner-Cremer F, et al. (2013) Climate change during the past 1000 years: A high-temporal-resolution multiproxy record from a mire in northern Finland. Journal of Quaternary Science 28(2): 152-164: doi:10.1002/jqs.2598.

Flynn DFB and Wolkovich EM (2018) Temperature and photoperiod drive spring phenology across all species in a temperate forest community. New Phytologist 219(4): 1353-1362: doi:10.1111/ nph.15232.

Franks PJ and Beerling DJ (2009) Maximum leaf conductance driven by $\mathrm{CO} 2$ effects on stomatal size and density over geologic time. Proceedings of the National Academy of Sciences of the United States of America 106(25): 10343-10347: doi:10.1073/pnas.0904209106.

Gräler B, Pebesma E and Heuvelink G (2016) Spatio-Temporal Interpolation using gstat. RFID Journal 8(1): 204-218: doi:10.32614/rj-2016-014.

Habjørg A (1971) Effects of photoperiod and temperature on growth and development of three latitudinal and three altitudinal populations of Betula pubescens EHRH. Meldinger fra Norges landbrukshøgskole 44(26): 1-27. 
Hijmans RJ (2018) raster: Geographic Data Analysis and Modeling. . Available at: https://cran.r-project. org/package=raster.

Körner C and Basler D (2010) Plant science. Phenology under global warming. Science (New York, N.Y.) 327(5972): 1461-2. Available at: http://www.ncbi.nlm.nih.gov/pubmed/20299580: doi:10.1126/ science. 1186473.

Kürschner WM (1997) The anatomical diversity of recent and fossil leaves of the durmast oak ( Quercus petraea Lieblein / Q . pseudocastanea Goeppert) - implications for their use as biosensors of palaeoatmospheric CO2 levels. Review of Palaeobotany and Palynology 6667(96).

Kürschner WM, van der Burgh J, Visscher H and Dilcher DL (1996) Oak leaves as biosensors of late neogene and early pleistocene paleoatmospheric CO2 concentrations. Marine Micropaleontology 27(1-4): 299-312: doi:10.1016/0377-8398(95)00067-4.

Lammertsma El, de Boer HJ, Dekker SC, Dilcher DL, Lotter AF and Wagner-Cremer F (2011) Global $\mathrm{CO} 2$ rise leads to reduced maximum stomatal conductance in Florida vegetation. Proceedings of the National Academy of Sciences 108(10): 1-6: doi:10.1073/pnas.1100371108.

Lian X, Piao S, Huntingford C, Li Y, Zeng Z, Wang X, et al. (2018) Partitioning global land evapotranspiration using CMIP5 models constrained by observations. Nature Climate Change. Springer US 8(7): 640-646. Available at: http://dx.doi.org/10.1038/s41558-018-0207-9.

McElwain JC and Steinthorsdottir M (2017) Paleoecology, Ploidy, Paleoatmospheric Composition, and Developmental Biology: A Review of the Multiple Uses of Fossil Stomata. Plant Physiology 174(2): 650-664. Available at: http://www.plantphysiol.org/lookup/doi/10.1104/pp.17.00204: doi:10.1104/ pp.17.00204.

McMaster GS and Wilhelm WW (1997) Growing degree-days: one equation, two interpretations. Agricultural and Forest Meteorology 87(1): 291-300.

Pebesma EJ and Bivand RS (2005) Classes and methods for spatial data in R. . Available at: https:// cran.r-project.org/doc/Rnews/.

Piao S, Liu Z, Wang T, Peng S, Ciais P, Huang M, et al. (2017) Weakening temperature control on the interannual variations of spring carbon uptake across northern lands. Nature Climate Change 7(May). Available at: http://www.nature.com/doifinder/10.1038/nclimate3277: doi:10.1038/nclimate3277.

Polgar CA and Primack RB (2011) Leaf-out phenology of temperate woody plants: from trees to ecosystems. 926-941: doi:10.1111/j.1365-2486.2005.01097.x.

R Core Team (2019) R: A Language and Environment for Statistical Computing. Vienna, Austria: R Foundation for Statistical Computing. Available at: https://www.r-project.org/.

Royer DL (2001) Stomatal density and stomatal index as indicators of paleoatmospheric CO2concentration. Review of Palaeobotany and Palynology 114(1-2): 1-28: doi:10.1016/S00346667(00)00074-9.

Shepard D (1964) A two-dimensional interpolation for irregularly-spaced data function. Proc. Ass. Comput. Mach. 517-524.

Steinthorsdottir M, Elliott-Kingston C and Bacon KL (2018) Cuticle surfaces of fossil plants as a 
potential proxy for volcanic SO2 emissions: observations from the Triassic-Jurassic transition of East Greenland. Palaeobiodiversity and Palaeoenvironments. Palaeobiodiversity and Palaeoenvironments 98(1): 49-69: doi:10.1007/s12549-017-0297-9.

Vaarama A and Valanne T (1973) On the taxonomy, biology and origin of Betula tortuosa Ledeb. Kevo Subarct. Res. Stn. 10: 70-84.

van Oldenborgh GJ, Drijfhout S, van Ulden A, Haarsma R, Sterl A, Severijns C, et al. (2009) Western Europe is warming much faster than expected. Climate of the Past 5(1): 1-12: doi:10.5194/cp-5-12009.

Wagner-Cremer F, Finsinger W and Moberg A (2010) Tracing growing degree-day changes in the cuticle morphology of Betula nana leaves: A new micro-phenological palaeo-proxy. Journal of Quaternary Science 25(6): 1008-1017: doi:10.1002/jqs.1388.

Wagner-Cremer F and Lotter AF (2011) Spring-season changes during the Late Pleniglacial and Bølling/Allerød interstadial. Quaternary Science Reviews 30(15-16): 1825-1828. Available at: http:// linkinghub.elsevier.com/retrieve/pii/S0277379111001399: doi:10.1016/j.quascirev.2011.05.003.

Wagner F, Kouwenberg LLR, Van Hoof TB and Visscher H (2004) Reproducibility of Holocene atmospheric CO2 records based on stomatal frequency. Quaternary Science Reviews 23(18-19): 1947-1954: doi:10.1016/j.quascirev.2004.04.003.

Wagner F, Neuvonen S, Kürschner WM and Visscher H (2000) The influence of hybridization on epidermal properties of birch species and the consequences for palaeoclimatic interpretations. Plant Ecology 148(1): 61-69: doi:10.1023/A:1009801614786.

Wagner F, Visscher H, Kurschner WM and Dilcher DL (2007) Influence of Ontogeny and Atmospheric $\mathrm{CO} 2$ on Stomata Parameters of Osmunda regalis. CFS Courier Forschungsinstitut Senckenberg 258: 183-189. Available at: http://kbd.kew.org/kbd/detailedresult.do?id=379688.

Weijers S, Wagner-Cremer F, Sass-Klaassen U, Broekman R and Rozema J (2013) Reconstructing High Arctic growing season intensity from shoot length growth of a dwarf shrub. The Holocene 23(5): 721-731. Available at: http://journals.sagepub.com/doi/10.1177/0959683612470178: doi:10.1177/0959683612470178.

Wickham H (2016) ggplot2: Elegant Graphics for Data Analysis. New York: Springer-Verlag. Available at: http://ggplot2.org.

Zohner CM, Benito BM, Svenning JC and Renner SS (2016) Day length unlikely to constrain climatedriven shifts in leaf-out times of northern woody plants. Nature Climate Change 6(12): 1120-1123: doi:10.1038/nclimate3138.

Zohner CM and Renner SS (2014) Common garden comparison of the leaf-out phenology of woody species from different native climates, combined with herbarium records, forecasts long-term change. Ecology Letters 17(8): 1016-1025: doi:10.1111/ele.12308. 


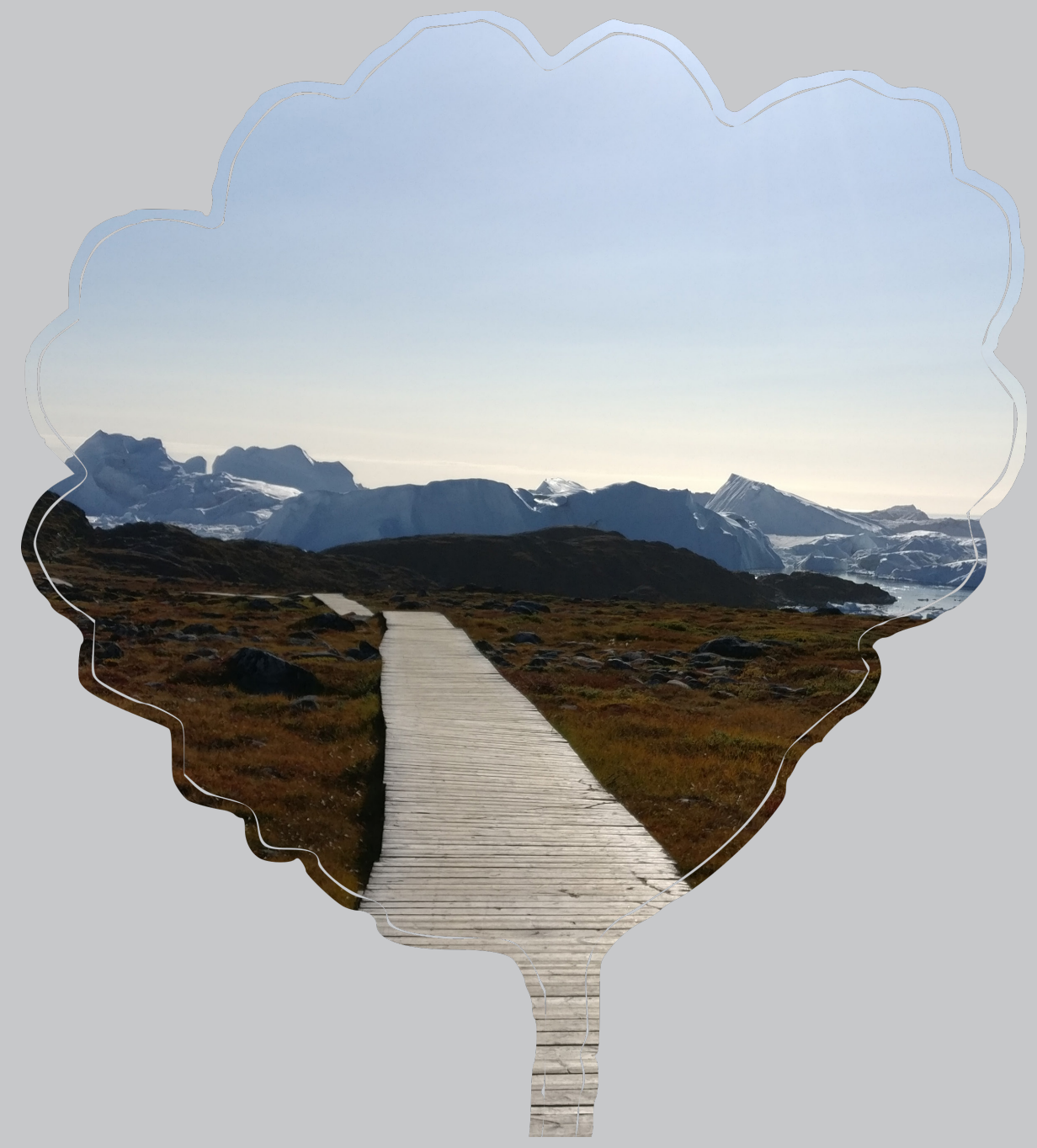




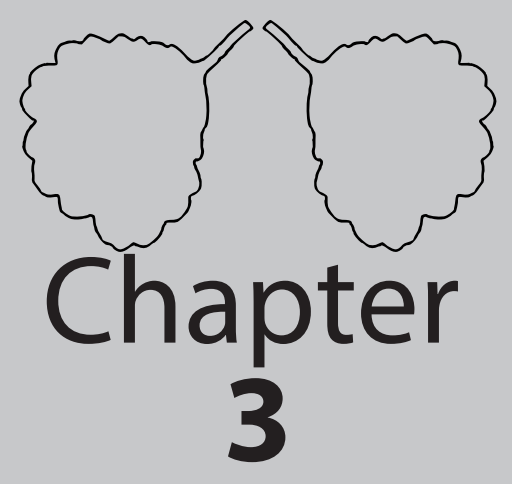




\title{
Effects of experimental warming on Betula nana epidermal cell growth tested over its maximum climatological growth range
}

\author{
Fabian E.Z. Ercan $^{1,3} \mid$ Juha Mikola ${ }^{2,3} \mid$ Tarja Silfver $^{2,3} \mid$ Kristiina Myller ${ }^{4,3}$ \\ Elina Vainio ${ }^{3}$ |Sandra Słowińska ${ }^{5}$ Michał Słowiński ${ }^{5}$ | Mariusz Lamentowicz ${ }^{5}$ \\ Daan Blok ${ }^{6}$ | Friederike Wagner-Cremer ${ }^{1,3}$ \\ ${ }^{1}$ Palaeoecology, Department of Physical Geography, Utrecht University Utrecht, The Netherlands \\ ${ }^{2}$ Faculty of Biological and Environmental Sciences, Ecosystems and Environment Research \\ Programme, University of Helsinki, Lahti, Finland \\ ${ }^{3}$ Kevo Subarctic Research Institute, Biodiversity Unit of the University of Turku, Utsjoki, Finland \\ ${ }^{4}$ Department of Environmental and Biological Sciences, University of Eastern Finland, Kuopio, \\ Finland \\ ${ }^{5}$ Polish Academy of Sciences, Institute of Geography and Spatial Organization, Department of \\ Geoecology and Climatology, Warsaw, Poland \\ ${ }^{6}$ Dutch Research Council (NWO), DenHaag, The Netherlands.
}

As published in PLOS ONE, 2021 


\subsection{Abstract}

Numerous long-term, free-air plant growth facilities currently explore vegetation responses to the ongoing climate change in northern latitudes. Open top chamber (OTC) experiments as well as the experimental set-ups with active warming focus on many facets of plant growth and performance, but information on morphological alterations of plant cells is still scarce. Here we compare the effects of in-situ warming on leaf epidermal cell expansion in dwarf birch, Betula nana in Finland, Greenland, and Poland. The localities of the three in-situ warming experiments represent contrasting regions of $B$. nana distribution, with the sites in Finland and Greenland representing the current main distribution in low and high Arctic, respectively, and the continental site in Poland as a B. nana relict Holocene microrefugium.

We quantified the epidermal cell lateral expansion by microscopic analysis of $B$. nana leaf cuticles. The leaves were produced in paired experimental treatment plots with either artificial warming or ambient temperature. At all localities, the leaves were collected in two years at the end of the growing season to facilitate between-site and within-site comparison. The measured parameters included the epidermal cell area and circumference, and using these, the degree of cell wall undulation was calculated as an Undulation Index (UI). We found enhanced leaf epidermal cell expansion under experimental warming, except for the extremely low temperature Greenland site where no significant difference occurred between the treatments. These results demonstrate a strong response of leaf growth at individual cell level to growing season temperature, but also suggest that in harsh conditions other environmental factors may limit this response. Our results provide evidence of the relevance of climate warming for plant leaf maturation and underpin the importance of studies covering large geographical scales. 


\subsection{Introduction}

A warmer environment affects plant growth and metabolism, causes shifts in phenology, and alters survival and reproductive success (Birks, 2020; Huang et al., 2020). Such adjustments in vegetation are expected to be especially pronounced in northern high latitudes, where ongoing climate change leads to rapidly warming growth conditions (IPCC, 2019). In order to quantify and predict future vegetation dynamics, field experiments are performed in various sites across the globe. Such in-situ experiments generate realistic settings, where environmental background conditions are maintained, while relevant abiotic growth parameters such as temperature are adjusted (Bjorkman et al., 2020; Myers-Smith et al., 2019). The majority of results from experimental plot-based studies indicate that Arctic plant species as well as plant communities are sensitive to warming, but response intensity and trends can be complex, sometimes contrasting or with no apparent change (Bjorkman et al., 2020).

Of special interest are phenological observations as changes in the life cycle of plants have a profound impact on biotic ecosystem properties, including e.g. total biomass production and reproduction capacity (Prevéy et al., 2017; Tackeray et al., 2016), but also on abiotic properties such as hydrology and surface albedo (Raynolds et al., 2013). As phenology directly influences plant performance and fitness, it can be used to model variations in plant success and ecological potential as a result of climate change (Chuine, 2010; Chuine and Beaubien, 2001; Fox, 2003; Prevéy et al., 2017). Leaf level responses in experimental set-ups are largely quantified in traits that concern whole leaves such as timing of phenological events, total and specific leaf area and leaf chemistry, including leaf $\mathrm{N}$ content (Prevéy et al., 2017). The ontogenetic succession of leaf growth and maturation, however, is understudied although the degree of leaf maturity is an important indication for response potential to such minor changes in growth conditions that might not be captured by using other traits (Wagner-Cremer et al., 2010b).

Final leaf size develops during the maturation phase, i.e. once the initial cell division is completed, through lateral expansion of leaf epidermal cells (Tichá, 1985; Wagner et al., 2007). Analysis of epidermal cell properties is commonly done by microscopic analysis of the cuticle, which enables a detailed determination of cell size and shape (Ercan et al., 2020; Wagner-Cremer et al., 2010b). A very indicative feature of lateral epidermal cell ontogeny is the size of epidermal cells and the degree of sinuosity of the epidermal cell walls, whole relation is quantified as the 
undulation index (UI) (Ercan et al., 2020; Kürschner, 1997a; Steinthorsdottir et al., 2019; Wagner-Cremer et al., 2010b). This microphenological trait is closely related to the prevailing air temperature during the growing season, as has been shown for dwarf birch, Betula nana (L.) in long-term single-site studies (Wagner-Cremer et al., 2010b) and for downy birch, B. pubescens (Ehrh.) in spatial analysis of leaves grown in Scandinavia during individual years (Ercan et al., 2020).

These time-series and spatial studies have clearly shown that the UI trait acclimatizes to the intensity of the growing season, commonly expressed as growing degree days (GDD), a cumulative sum of daily degrees Celsius reached throughout the year (Carter, 1998). After the initial leaf epidermal cell division and specialization, the lateral epidermal cell expansion first leads to an increase in cell size and then successively to a higher cell circumference to cell size ratio, quantified by using the UI (Wagner et al., 2007). The final stage of development reached thus depends on the length and warmth of the available growth period: long and warm seasons lead to large and highly undulated epidermal cells, while short and cold seasons suppress full maturation (Wagner-Cremer et al., 2010b). The effect of GDD on UI was originally quantified as a 'paleothermometer' where UI of (sub-) fossil $B$. nana epidermis material from sedimentary archives provided growing season temperature reconstructions for episodes of past climate change (Finsinger et al., 2013; Steinthorsdottir et al., 2019; Wagner-Cremer et al., 2010b). Apart from GDD influence on UI, differences in light availability has also been documented to affect UI (Bush et al., 2017; Cheesman et al., 2020; Dunn et al., 2015; Thomas et al., 2004). The significance of measuring the $\mathrm{UI}$ trait in experimental studies in the context of GDD lies in the tie-in with paleo studies and an improved insight into the plasticity, adaptation, and future change of leaf cell maturation. These aspects are hard to detangle in space-for-time substitution studies (Bjorkman et al., 2018; Prevéy et al., 2017), where the range of acclimatization and adaptation potential are not investigated. Betula nana today is a key-species of the low-Arctic tundra. It is commonly present in experimental sites and is one of the species that is predicted to undergo an increase or expansion in the Arctic greening and shrubification scenarios (Buchwal et al., 2019; Piao et al., 2019).

In the present study, we make use of the full availability of $B$. nana in warming experiments to investigate the ontogenetic sensitivity of leaf growth to simulated warming in contrasting geographical regions. We apply the UI to B. nana leaves collected at Blæsedalen on Disko Island (Qeqertarsuaq) in west Greenland, to leaves collected at Kevo in northernmost Finnish Lapland (Silfver et al., 2020), and 
to leaves collected at the $B$. nana relic stand of Linje Mire in northern Poland (Jassey et al., 2018; Lamentowicz et al., 2016).

The main aim of our microphenological approach is to test and quantify B. nana leaf ontogenetical adjustments and sensitivity to future warmer climate simulated in plot-based experimental set ups.

\subsection{Materials and Methods}

The selected locations represent different areas of $B$. nana distribution, with two (sub-)Arctic sites in Finland and Greenland and a continental site in Poland (Figure 3.1). For all localities we studied leaf samples collected from plots with ambient temperature and those collected from plots treated with either open top chambers (OTC) or ceramic heaters to induce warming (Table 3.1). For each site we also studied samples from two years to facilitate a within-site comparison. By comparing years within site we are able to test the responsiveness of $B$. nana UI to warming under different local conditions, while the between-site comparison allows the analysis of the sensitivity of UI on a large spatial scale covering much of the distribution range of B. nana.

Table 3.1: Experimental sites and their properties.

\begin{tabular}{|l|l|l|l|}
\hline Site & Experimental setup & $\begin{array}{l}\text { Average warming } \\
\text { above ambient }\left({ }^{\circ} \mathrm{C}\right)\end{array}$ & $\begin{array}{l}\text { Number of used } \\
\text { plots }\end{array}$ \\
\hline Kevo station, FI & Active warming & 3.3 & $14(2017), 5(2018)$ \\
\hline Linje Mire, PL & OTC & 1.5 & $6(2016), 5(2018)$ \\
\hline Blæsedalen, GN & OTC & 2.5 & $6(2013), 5(2017)$ \\
\hline
\end{tabular}


Effects of experimental warming on Betula nana epidermal cell growth tested over its maximum climatological growth range

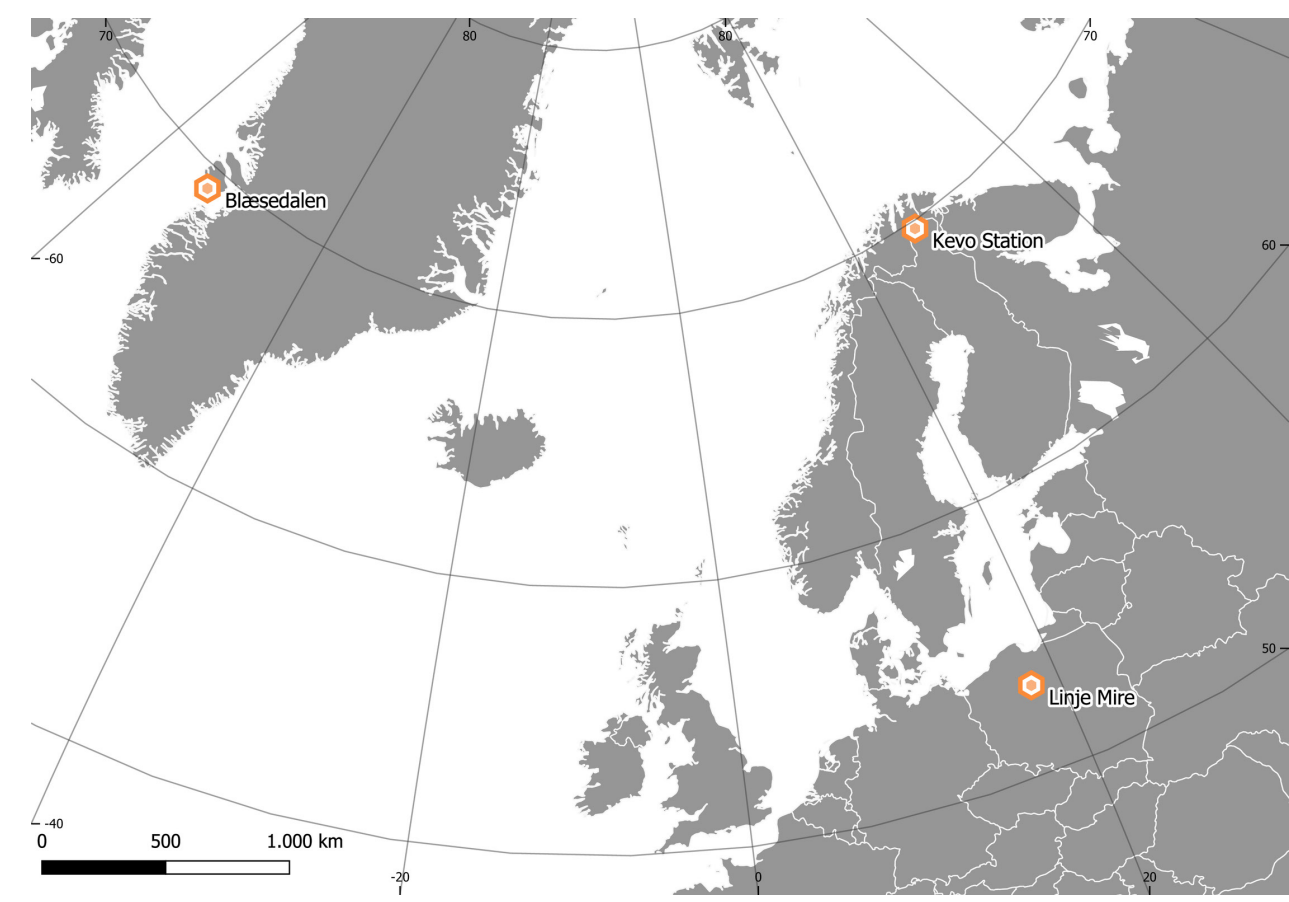

Figure 3.1: Locations of the experimental sites. Map created with QGIS (QGIS Development Team, 2021), shape files downloaded from (Tapiquén, 2020). 


\subsubsection{Experimental Sites}

\section{Greenland}

The CENPERM OTC set-up, see figure 3.2a, is located at a mesic tundra site in the Blæsedalen valley, Qeqertarsuaq/Disko Island, West Greenland (69 16 N $\left.53^{\circ} 27 \mathrm{~W}\right)$ (Blok et al., 2016a). The leaves available to this study were sampled in 2013 and 2017. Disko Island is a large island off the west coast of Greenland. It is located near the transitional zone between the low and high Arctic. The study site is a tundra/dry mixed shrub heath, dominated mainly by B. nana, Vaccinium vitis-idaea, Empetrum nigrum, Salix glauca, Cassiope tetragona, and lichens. The mean annual temperature at Blæsedalen is $-3^{\circ} \mathrm{C}(1992-2012)$ with an average precipitation of $436 \mathrm{~mm}$ per year (1991-2004). The OTC set-up realizes an average warming of $2.5^{\circ} \mathrm{C}$ and compared to ambient surface air temperatures in spring and summer (Zhang et al., 2019). The experiment was also designed to measure active layer-permafrost interactions, involving a plot treatment of shrub removal and a plot treatment facilitating extra snow cover. These treatments are not used in this study.

\section{Finland}

The Kevo open-air warming experiment, see figure $\mathbf{3 . 2} \mathbf{b}$, is situated at the Turku University Kevo Subarctic Research Institute in the northernmost Finnish Lapland $\left(69^{\circ} 45.4 \mathrm{~N}, 27^{\circ} 00.5 \mathrm{E}\right)$ (Silfver et al., 2020). Betula nana was not originally growing in the experimental site but was planted in the experimental plots as cloned plantlets of three B. nana genotypes in 2016 (Silfver et al., 2020). The leaves from these plantlets were sampled in 2017 and 2018. Apart from leaves from the warming experiment, annual monitoring of natural leaf microphenology is available in Kevo since 1996. Kevo lies within the low Arctic, or Subarctic and is characterized by a relatively mild climate. The locality is situated in the mountain birch Betula pubescens subsp. czerepanovii forest-tundra ecotone, with the local Scots pine Pinus sylvestris tree line $60 \mathrm{~km}$ to the south. The mean annual temperature at Kevo was $-0.3^{\circ} \mathrm{C}$ in 2017 and $0.5^{\circ} \mathrm{C}$ in 2018 , with a precipitation of $490 \mathrm{~mm}$ and $375 \mathrm{~mm}$, respectively. The experimental set-up included ten ambient (control) plots and ten plots, where green metal plates (mimicking plant leaves) were heated to approximately 3.3 ${ }^{\circ} \mathrm{C}$ above ambient temperature using real-time temperature measurements and microprocessor-based control of infrared ceramic heaters (Silfver et al., 2020). During 2016-2018 growing seasons, warming led to approximately $2.3^{\circ} \mathrm{C}$ warmer moving air and $1.2{ }^{\circ} \mathrm{C}$ warmer soil in the heated plots (Silfver et al., 2020). The 

tested over its maximum climatological growth range

experiment also contained - in a fully factorial $2 \times 2$ design - a herbivory reduction treatment with ten plots of natural insect herbivory and ten plots with reduced insect herbivory (Silfver et al., 2020). The experiment also included a mix of plots with altered and natural herbivory regimes. In 2018, due to extreme temperatures, only the surviving plots $(n=5)$ were used.

\section{Poland}

The CLIMPEAT OTC set-up, see figure 3.2c, is located at the nutrient poor fen Linje Mire at the border between a moraine hill and a sandur with a system of dunes, close to the northern Polish city of Bydgoszcz (53 $11 \mathrm{~N}, 18^{\circ} 18 \mathrm{E}$ ) (Słowińska et al., 2010). The leaves used in this study were sampled in 2016 and 2018. Linje Mire is particularly interesting because it is the only location in lowland Poland that maintains a glacial relict population of the arctic shrub B. nana, that has been growing in the area since the Allerød. The bog is dominated by Sphagnum and surrounded by a mixed forest. The mean annual temperature of the region is $8.5^{\circ} \mathrm{C}$ with an average precipitation of 540mm per year (1981-2010, Institute of Meteorology and Water Management-NRI). The site is located at an intersection for oceanic and continental air masses and thus has intermediate air conditions (Słowińska et al., 2010). The OTC set-up realizes a maximum average warming of $1.5^{\circ} \mathrm{C}$ compared to ambient temperatures (Lamentowicz et al., 2016).

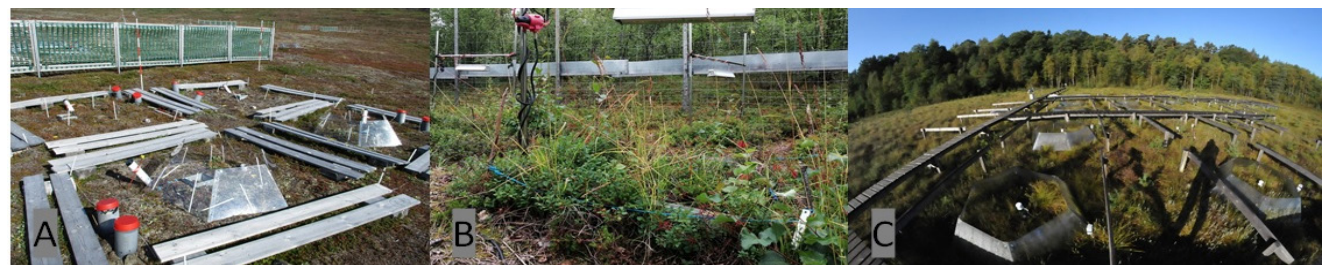

Figure 3.2: In-situ warming experiments: (a) CENPERM OTC set-up on Disko Island, Greenland (b) open-air warming experiment in Kevo, Finland (c) CLIMPEAT OTC in Linje Mire, Poland. 


\subsubsection{Microphenology}

In each treatment plot, three to five leaves used in this study were sampled from one $B$. nana individual at the end of the growing season. From each leaf, three sections of $0.5 \mathrm{~cm} \times 0.5 \mathrm{~cm}$ area were bleached in sodium hypochlorite $(<5 \%)$ for 12-24 hours. The epidermal cell properties of three leaves per plot were then analysed using a Leica DM LB2 microscope and an AnalySIS image analysis system (Figure 3.3). Computer-aided analysis of epidermal and stomatal cell properties was performed using ImageJ 1.52a.

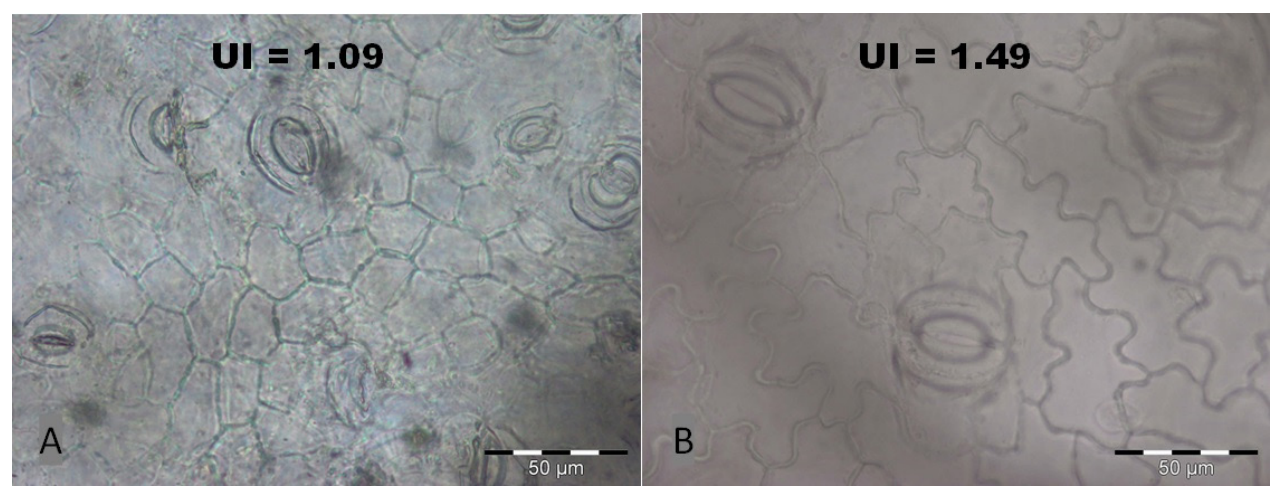

Figure 3.3: Microscopic pictures from B. nana leaf fragments. Stomata bearing alveole areas and epidermal cells with (a) low (UI: 1.09) and (b) very high (UI: 1.49) average cell wall undulation. Scale bar is $50 \mu \mathrm{m}$.

To estimate the mean epidermal cell area $\left(C A ;\left[\mu m^{2}\right]\right)$ and epidermal cell circumference $(C C ;[\mu \mathrm{m}]), 30$ random pavement cells per leaf were analysed, avoiding cells over venation and leaf margins. From CA and CC, the undulation index (Ul; dimensionless) of the epidermal cell wall was calculated (Equation 3.1) following Kürschner (Kürschner, 1997b).

$$
U I[\text { dimensionless }]=\frac{C C}{2 \pi \cdot \sqrt{C A / \pi}}
$$

[Equation 3.1] 


\subsubsection{Statistical comparison}

The statistical significance of differences in mean UI values between the control and warming treatments were tested for each site using a paired Student's t-test. All statistical analysis performed in R statistical software with the package ggplot2 (R Core Team, 2020; Wickham, 2016).

\subsubsection{Meteorological data}

To allow comparison of cuticle analysis results to local weather conditions, data of mean daily temperatures and precipitation were collected from weather stations nearest to each sampling site.

$\mathrm{GDD}_{5}$ was then calculated (Equation 3.2) using daily temperatures recorded throughout the growing season (Blok et al., 2016b; Lamentowicz et al., 2016; Silfver et al., 2020). GDD covers the growing potential for vegetation in a given growing season and is expressed by the cumulative sum of degrees Celsius above a chosen base temperature (Carter, 1998; McMaster and Wilhelm, 1997; Weijers et al., 2013).

$$
G D D_{X}=\sum_{i=1}^{\# \text { days }}\left(T_{i}-X\right), \quad T_{i} \geq X
$$

[Equation 3.2]

where $\mathrm{Ti}$ is the mean temperature for day $\mathrm{i}$ in the particular site and $\mathrm{X}$ is the selected threshold temperature in degrees Celsius. For the latitudinal range covered in this study, $5^{\circ} \mathrm{C}$ is the commonly used threshold temperature for plant growth and was thus chosen as the threshold temperature X (Carter, 1998).

\subsection{Results}

The B. nana epidermal cell UI was compared between the ambient, or control (C) temperature and warming (W) for each site (Figure 3.4). The over-all UI data ranged from 1.11 to 1.33 , and in Finland and Poland, warming yielded higher UI values than the ambient temperature, whereas in Greenland, no significant differences were detected. 
The ambient temperature and warming treatment growing season $\mathrm{GDD}_{5}$ values for each experiment are shown in table 3.2. The warming treatments caused a temperature increase of $1.5-3.3^{\circ} \mathrm{C}$, which lead to a GDD 5 increase of 231-302.

Table 3.2: GDD5 at the moment of leaf sampling and mean UI.

\begin{tabular}{|l|l|l|l|l|l|}
\hline Location & $\begin{array}{l}\text { Ambient } \\
\text { GDD }\end{array}$ & $\begin{array}{l}\text { Warmed } \\
\text { GDD } 5\end{array}$ & $\begin{array}{l}\text { Mean UI } \\
\text { ambient }\end{array}$ & $\begin{array}{l}\text { Mean UI } \\
\text { warming }\end{array}$ & P-value \\
\hline $\begin{array}{l}\text { Finland } \\
(\mathbf{2 0 1 7})\end{array}$ & 597 & 828 & 1.20 & 1.25 & $0.01, n=14$ \\
\hline $\begin{array}{l}\text { Finland } \\
(\mathbf{2 0 1 8})\end{array}$ & 900 & 1200 & 1.16 & 1.21 & $0.03, n=5$ \\
\hline $\begin{array}{l}\text { Greenland } \\
(\mathbf{2 0 1 3 )}\end{array}$ & 174 & 332 & 1.14 & 1.14 & $0.65, n=6$ \\
\hline $\begin{array}{l}\text { Greenland } \\
(\mathbf{2 0 1 7})\end{array}$ & 123 & 253 & 1.13 & 1.13 & $0.93, n=5$ \\
\hline $\begin{array}{l}\text { Poland } \\
(\mathbf{2 0 1 6 )}\end{array}$ & 1882 & $\begin{array}{l}2184 \text { (calculated } \\
\text { max) }\end{array}$ & 1.14 & 1.20 & $0.01, n=6$ \\
\hline $\begin{array}{l}\text { Poland } \\
\text { (2018) }\end{array}$ & 2183 & $\begin{array}{l}2477 \text { (calculated } \\
\text { max) }\end{array}$ & 1.18 & 1.22 & $0.02, n=5$ \\
\hline
\end{tabular}




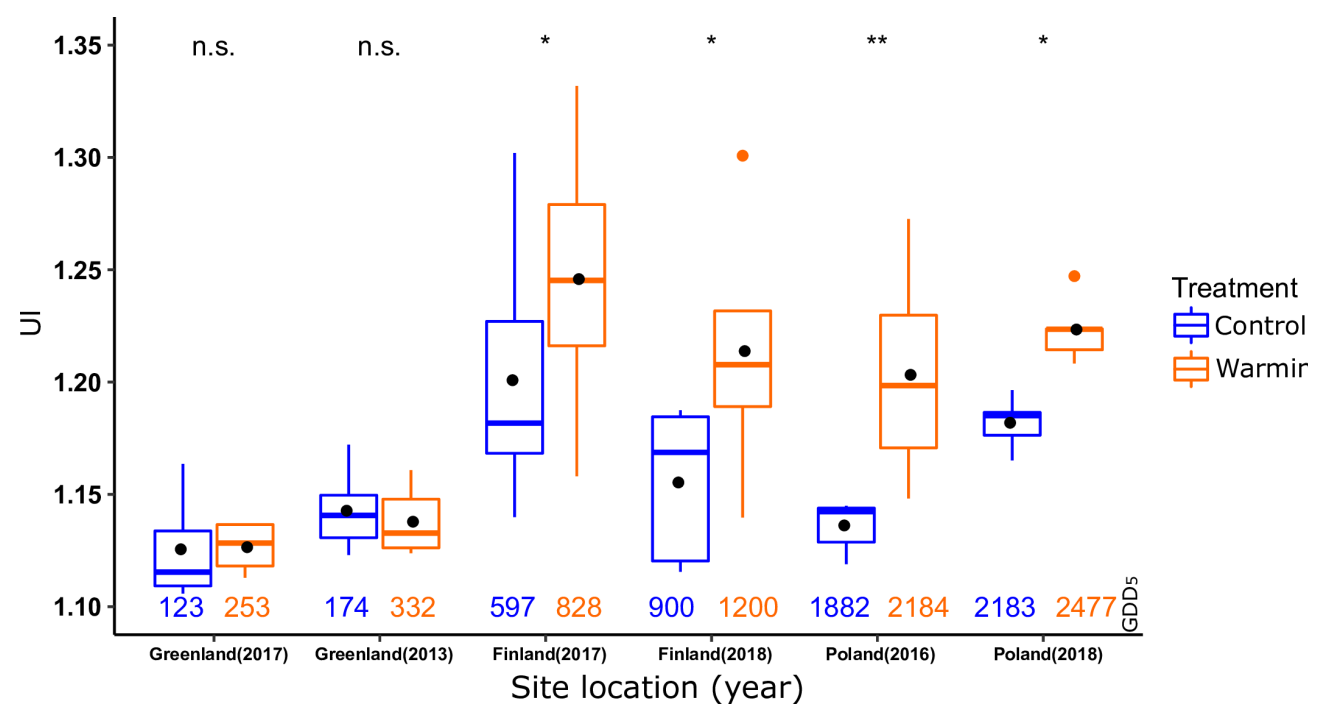

Figure 3.4: $B$. nana epidermal cell UI median (horizontal lines in boxplots) and mean (black dots) values for control $(\mathrm{C})$ and warming $(\mathrm{W})$ treatments in the different locations and years. T-test $p$ values are indicated with ${ }^{*}$ for $<0.05,{ }^{* *}$ for $<0.01$ and n.s. for not significant, indicating the statistical significance for differences between UI means (dots) in control and warming treatments. Numbers underneath the boxplots indicate GDDs totals under which the plants have grown, green for ambient control values and red for experimental warming values.

\subsection{Discussion}

In this study, we compared the microphenological response of $B$. nana to artificial warming between experimental set-ups across the B. nana distribution. Two locations, in Finland and Greenland, are within the current distribution in the low-Arctic, while the third location in Poland is an isolated glacial relict stand (Noryśkiewicz, 2005; Słowińska et al., 2010).

The ratio between cell circumference and cell area is summarized as the $\mathrm{UI}$ of the epidermal cells. The experiments in Finland and Poland consistently show the expected response of higher $\mathrm{Ul}$ in the warming treatment compared to the control treatment in both individual years studied (Figure 3.4). This temperature response is in line with results from previous time-series data for B. nana collected in Kevo, Finland (Steinthorsdottir et al., 2019; Wagner-Cremer et al., 2010b) and studies of B. pubescens and mountain birch hybrids over a latitudinal temperature gradient in Scandinavia that both document the strong positive correlation between GDD and UI (Ercan et al., 2020). Further experimental evidence of the generality of the 
observed temperature response comes from climate chamber trials, where $B$. pendula UI values increased significantly with increasing chamber temperatures of $12{ }^{\circ} \mathrm{C}, 20^{\circ} \mathrm{C}$ and $30^{\circ} \mathrm{C}$ in multiple weeks treatments (Wagner, 1998).

The diverging trends observed in the experiments performed in Greenland provide interesting information on the limits in leaf growth under extremely low temperature conditions. Compared to Finland and Poland, in Greenland the GDD5 values were very low, ranging between ambient 123 and 332 in the warming treatment. This means that the cumulative growing season temperature available to $B$. nana growth is only a fraction of what is available in the other sites. In both years on Greenland, 2013 and 2017, the difference between treatments was not significant. It has earlier been shown that the growth response of plants to warming in experiments can be reduced or absent, probably due to other limiting factors, when performed in an extreme part of a plants habitat range (Hobbie et al., 2017), compared to a more forgiving area. In the study by Hobbie et al. (Hobbie et al., 2017), no vegetation and shrub biomass responses to environmental change were found in a more extreme site in Zackenberg, Greenland, while there was a biomass response in a less extreme site in Toolik, Alaska.

That temperature alone, however, does not fully govern UI development is also revealed by a comparison of data from Finland and Poland in our study. The experiment at Linje, Poland yielded lower UI values than the experiment in Kevo, Finland, although the yearly GDD is remarkably higher in Poland. This discrepancy has to be attributed to environmental conditions other than temperature, like nutrient deficiency in the Linje mire fen that create sub-optimal conditions for UI development (Hájek et al., 2006; Słowińska et al., 2010). The influence of light induced UI changes, as described by Thomas et al. (2003) in tobacco and used in phytolith based proxies by Dunn et al. (2015), can be neglected since all of the experiment designs allow for optimal B. nana light conditions (Dunn et al., 2015; Thomas et al., 2004). Growth chamber experiments performed with $B$. pendula subjected to different nitrogen supply levels resulted in significantly reduced UI in the N-limited experiments under ambient CO2 (Wagner, 1998) accompanied by reduced total shoot dry weight (DW g g-1) measured on the same plants (Petterson et al., 1993). These studies also suggest nutrient availability as an additional stress factor for overall leaf expansion and maturation (Wagner, 1998). In Kevo, the UI values were lower in 2018 than in 2017 although summer 2018 had higher GDD than summer 2017. Kevo experienced extreme drought in July 2018 (Silfver et al., 2020), which either suppressed leaf epidermal cell maturation (Gagen et al., 2011; 

tested over its maximum climatological growth range

Wagner-Cremer et al., 2010b) or induced an early leaf shed during the maximum drought phase followed by a second leaf generation after precipitation was received in the later part of the growing season. In the latter case, the studied samples will have had a shorter growth period which did not allow for maximum leaf expansion by the end of the 2018 growth season. That drought has an negative effect on epidermal cell expansion, however, has been shown in field studies with laurel oak (Quercus laurifolia) where epidermal cell expansion is strongly supressed by low precipitation amounts received during the growing period (Wagner-Cremer et al., 2010a). Which of these potential causes however ultimately led to the diverging results observed between the individual years in Kevo, is difficult to disentangle and required more studies on the role of drought stress in arctic vegetation.

Previous studies have highlighted the need for more inclusive, unified and geographically widespread monitoring efforts to better resolve the interacting effects of warming and other local and regional ecological factors (Bjorkman et al., 2020; Prevéy et al., 2017). In our study, we covered a large geographical area by carrying out the same analysis with plant material collected from comparable experiments in different locations. This approach revealed the potential restrictions imposed by local habitat and temperature ranges for plant physiological responses to warming.

The Polish and Finnish experiments showed that the epidermal UI in B. nana increases under elevated temperatures from temperate to low Arctic regions. Such plasticity and sensitivity to a subtle, but relevant, increase in temperature indicate that $B$. nana has the necessary physiological reactiveness to undergo enhanced plant performance under future warmer climate. However, this potential may not emerge in more extreme environmental conditions of $B$. nana distribution, as shown in the Greenland experiment. The response of $P$. sylvestris survival and growth to increasing GDD in tree line conditions was recently shown to depend heavily on soil fertility (Rousi et al., 2018). It is possible that water and nutrient availability also restricts the response of $B$. nana leaf cell development, and for this reason, no warming effect was found in Greenland. In sites with enhanced plant performance, higher temperatures will likely lead to plant communities with higher number and larger size of $B$. nana as well as expansion of $B$. nana into previously unsuitable areas (Bintanja et al., 2020; Biskaborn et al., 2019; Chmura et al., 2019; Magnússon et al., 2020; Niskanen et al., 2019). This does not hold for the relic site of Linje Mire, Poland, however, as the environment involves species that would outcompete B. nana outside the refugium area. 
To conclude, we found further evidence that B. nana can react to a warmer environment in terms of plant performance, which in our case was reflected in microphenology, i.e., in the Ul of leaf epidermal cells. As this reaction to temperature is produced within one leaf generation, it is responsive to yearly weather variation and sensitive enough for representing growing season intensity. The potential of B. nana as one of the key plant species of tundra to increase its performance under climate warming underlines the probability of the Arctic greening scenario. Shrub expansion in the High Arctic is projected to accelerate. However, our results suggest that under the more extreme conditions of the species' distribution range towards the High Arctic, where other limiting factors might still be at play, only rudimentary increase in $B$. nana growth may occur in moderate $\left(\sim 3^{\circ} \mathrm{C}\right)$ warming scenarios. Although, these limiting factors such as nutrient availability, soil humidity, shade, symbiotic relations, and growing season changes will change along with a warming climate in general, encouraging further combined experiments.

\subsection{Acknowledgements}

The authors would like to thank Bo Elberling and Anders Michelsen for granting access to the CENPERM research facilities and comments on the manuscript. The staff at Kevo Subarctic Research Station (Utsjoki, Finland), Arctic Station (Qeqertarsuaq, Greenland), the Linje Mire field experiment (Poland) and Wim Hoek are gratefully acknowledged for their assistance in the field. We thank Eva Baas, Thya van den Berg and Ronald van der Woude for contributing to the data production. 


\subsection{Literature}

Bintanja R, Wiel K Van Der, Linden EC Van Der, Reusen J and Bogerd L (2020) Strong future increases in Arctic precipitation variability linked to poleward moisture transport. Science Advances (February): 1-7: doi:DOI: 10.1126/sciadv.aax6869.

Birks HJB (2020) Reflections on the Use of Ecological Attributes and Traits in Quaternary Botany. 8(May): 1-13: doi:10.3389/fevo.2020.00166.

Biskaborn BK, Smith SL, Noetzli J, Matthes H, Vieira G, Streletskiy DA, et al. (2019) Permafrost is warming at a global scale. Nature Communications 10(1): 1-11: doi:10.1038/s41467-018-08240-4.

Bjorkman AD, García Criado M, Myers-Smith IH, Ravolainen V, Jónsdóttir IS, Westergaard KB, et al. (2020) Status and trends in Arctic vegetation: Evidence from experimental warming and long-term monitoring. Ambio 49(3): 678-692: doi:10.1007/s13280-019-01161-6.

Bjorkman AD, Myers-Smith IH, Elmendorf SC, Normand S, Rüger N, Beck PSA, et al. (2018) Plant functional trait change across a warming tundra biome. Nature 562(7725): 57-62: doi:10.1038/ s41586-018-0563-7.

Blok D, Elberling B and Michelsen A (2016a) Initial Stages of Tundra Shrub Litter Decomposition May Be Accelerated by Deeper Winter Snow But Slowed Down by Spring Warming. Ecosystems. Springer US 19(1): 155-169: doi:10.1007/s10021-015-9924-3.

Buchwal A, Weijers S, Blok D and Elberling B (2019) Temperature sensitivity of willow dwarf shrub growth from two distinct High Arctic sites. International Journal of Biometeorology. International Journal of Biometeorology 63(2): 167-181: doi:10.1007/s00484-018-1648-6.

Bush RT, Wallace J, Currano ED, Jacobs BF, McInerney FA, Dunn RE, et al. (2017) Cell anatomy and leaf $\delta 13 \mathrm{C}$ as proxies for shading and canopy structure in a Miocene forest from Ethiopia. Palaeogeography, Palaeoclimatology, Palaeoecology. Elsevier B.V.485:593-604. Available at: http://dx.doi.org/10.1016/j. palaeo.2017.07.015: doi:10.1016/j.palaeo.2017.07.015.

Carter TR (1998) Changes in the thermal growing season in Nordic countries during the past century and prospects for the future. Agricultural and Food Science 7(2): 161-179: doi:10.23986/afsci.72857.

Cheesman AW, Duff H, Hill K, Cernusak LA and McInerney FA (2020) Isotopic and morphologic proxies for reconstructing light environment and leaf function of fossil leaves: a modern calibration in the Daintree Rainforest, Australia. American Journal of Botany 107(8): 1165-1176: doi:10.1002/ajb2.1523.

Chmura HE, Kharouba HM, Ashander J, Ehlman SM, Rivest EB and Yang LH (2019) The mechanisms of phenology: the patterns and processes of phenological shifts. Ecological Monographs 89(1): 1-22: doi:10.1002/ecm.1337.

Chuine I (2010) Why does phenology drive species distribution? Philosophical Transactions of the Royal Society B: Biological Sciences 365(1555): 3149-3160: doi:10.1098/rstb.2010.0142.

Chuine I and Beaubien EG (2001) Phenology is a major determinant of tree species range. Ecology Letters 4(5): 500-510: doi:10.1046/j.1461-0248.2001.00261.x.

Dunn RE, Strömberg CAE, Madden RH, Kohn MJ and Carlini AA (2015) Linked canopy, climate, and faunal change in the Cenozoic of Patagonia. Science 347(6219): 258-261: doi:10.1126/

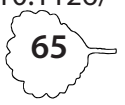


science.1260947.

Ercan FEZ, De Boer HJ and Wagner-Cremer F (2020) A growing degree day inference model based on mountain birch leaf cuticle analysis over a latitudinal gradient in Fennoscandia. Holocene 30(2): 344-349: doi:10.1177/0959683619865605.

Finsinger W, Schoning K, Hicks S, Lücke A, Goslar T, Wagner-Cremer F, et al. (2013) Climate change during the past 1000 years: A high-temporal-resolution multiproxy record from a mire in northern Finland. Journal of Quaternary Science 28(2): 152-164: doi:10.1002/jqs.2598.

Fox GA (2003) Assortative mating and plant phenology: Evolutionary and practical consequences. Evolutionary Ecology Research 5(1): 1-18.

Gagen M, Finsinger W, Wagner-Cremer F, Mccarroll D, Loader NJ, Robertson I, et al. (2011) Evidence of changing intrinsic water-use efficiency under rising atmospheric CO2 concentrations in Boreal Fennoscandia from subfossil leaves and tree ring ??13C ratios. Global Change Biology 17(2): 10641072: doi:10.1111/j.1365-2486.2010.02273.x.

Hájek M, Horsák M, Hájková P and Dítě D (2006) Habitat diversity of central European fens in relation to environmental gradients and an effort to standardise fen terminology in ecological studies. Perspectives in Plant Ecology, Evolution and Systematics 8(2): 97-114: doi:10.1016/j. ppees.2006.08.002.

Hobbie JE, Shaver GR, Rastetter EB, Cherry JE, Goetz SJ, Guay KC, et al. (2017) Ecosystem responses to climate change at a Low Arctic and a High Arctic long-term research site. Ambio 46: 160-173: doi:10.1007/s13280-016-0870-x.

Huang Y, Jiang N, Shen M and Guo L (2020) Effect of preseason diurnal temperature range on the start of vegetation growing season in the Northern Hemisphere. Ecological Indicators. Elsevier 112(December 2019): 106161. Available at: https://doi.org/10.1016/j.ecolind.2020.106161: doi:10.1016/j.ecolind.2020.106161.

IPCC (2019) IPCC, 2019: Climate Change and Land: an IPCC special report on climate change, desertification, land degradation, sustainable land management, food security, and greenhouse gas fluxes in terrestrial ecosystems. .

Jassey VEJ, Reczuga MK, Zielińska M, Słowińska S, Robroek BJM, Mariotte P, et al. (2018) Tipping point in plant-fungal interactions under severe drought causes abrupt rise in peatland ecosystem respiration. Global Change Biology 24(3): 972-986. Available at: https://onlinelibrary.wiley.com/doi/ abs/10.1111/gcb.13928: doi:10.1111/gcb.13928.

KürschnerWM (1997a) The anatomical diversity of recent and fossil leaves of the durmast oak (Quercus petraea Lieblein/ Quercus pseudocastanea Goeppert): implications for their use as biosensors of paleoatmospheric CO2 levels. Review of Palaeobotany and Palynology 96(96): 1-30.

Kürschner WM (1997b) The anatomical diversity of recent and fossil leaves of the durmast oak (Quercus petraea Lieblein/Q. pseudocastanea Goeppert) - Implications for their use as biosensors of palaeoatmospheric CO 2 levels. Review of Palaeobotany and Palynology 96(1-2): 1-30: doi:10.1016/ S0034-6667(96)00051-6.

Lamentowicz M and Słowińska, S., Słowiński, M., Jassey, V.E.J., Chojnicki, B.H., Reczuga, M.K., Zielińska, M., Marcisz, K., Lamentowicz, Ł., Barabach, J., Samson, M., Kołaczek, P., Buttler A (2016) Combining 
short-term manipulative experiments with long-term palaeoecological investigations at high resolution to assess the response of Sphagnum peatlands to drought, fire and warming. Mires and Peat. 18(20): 1-17.

Lamentowicz M, Słowińska S, Słowiński M, Jassey VEJ, Chojnicki BH, Reczuga MK, et al. (2016) Combining short-term manipulative experiments with long-term palaeoecological investigations at high resolution to assess the response of sphagnum peatlands to drought, fire and warming. Mires and Peat 18: 1-17: doi:10.19189/MaP.2016.OMB.244.

Magnússon Rí, Limpens J, van Huissteden J, Kleijn D, Maximov TC, Rotbarth R, et al. (2020) Rapid vegetation succession and coupled permafrost dynamics in Arctic thaw ponds in the Siberian lowland tundra. Journal of Geophysical Research: Biogeosciences.

McMaster GS and Wilhelm WW (1997) Growing degree-days: one equation, two interpretations. Agricultural and Forest Meteorology 87(1): 291-300.

Myers-Smith IH, Grabowski MM, Thomas HJD, Angers-Blondin S, Daskalova GN, Bjorkman AD, et al. (2019) Eighteen years of ecological monitoring reveals multiple lines of evidence for tundra vegetation change. Ecological Monographs 89(2): doi:10.1002/ecm.1351.

Niskanen AKJ, Niittynen P, Aalto J, Väre H and Luoto M (2019) Lost at high latitudes: Arctic and endemic plants under threat as climate warms. Diversity and Distributions (October 2018): 1-13: doi:10.1111/ddi.12889.

Noryśkiewicz AM (2005) A. Preliminary results of study on vegetation history in the Linje mire region using pollen analysis. Monographiae Botanicae 94: 117-134: doi:10.5586/MB.1960.002.

Petterson R, McDonald AJS and Stadenberg I (1993) Response of small birch plants (Betula pendula Roth.) to elevated CO2 and nitrogen supply. Plant Cell and Environment (16): 1115-1121.

Piao S, Liu Q, Chen A, Janssens IA, Fu Y, Dai J, et al. (2019) Plant phenology and global climate change: Current progresses and challenges. Global Change Biology 25(6): 1922-1940: doi:10.1111/gcb.14619.

Prevéy J, Vellend M, Rüger N, Hollister RD, Bjorkman AD, Myers-Smith IH, et al. (2017) Greater temperature sensitivity of plant phenology at colder sites: implications for convergence across northern latitudes. Global Change Biology 23: 2660-2671: doi:10.1111/gcb.13619.

R Core Team (2020) R: A Language and Environment for Statistical Computing. Vienna, Austria: R Foundation for Statistical Computing. Available at: https://www.r-project.org/.

Raynolds M, Walker D, Verbyla D and Munger C (2013) Patterns of change within a tundra landscape: 22-year landsat NDVI trends in an area of the northern foothills of the brooks range, Alaska. Arctic, Antarctic, and Alpine Research 45(2): 249-260: doi:10.1657/1938-4246-45.2.249.

Rousi M, Possen BJMH, Ruotsalainen S, Silfver T and Mikola J (2018) Temperature and soil fertility as regulators of tree line Scots pine growth and survival-implications for the acclimation capacity of northern populations. Global Change Biology 24(2): e545-e559: doi:10.1111/gcb.13956.

Silfver T, Heiskanen L, Aurela M, Myller K, Karhu K, Meyer N, et al. (2020) Insect herbivory dampens Subarctic birch forest $C$ sink response to warming. Nature Communications. Springer US 11(1): 1-9. Available at: http://dx.doi.org/10.1038/s41467-020-16404-4: doi:10.1038/s41467-020-16404-4.

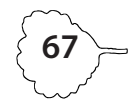


Słowińska S, Słowiński M and Lamentowicz M (2010) Relationships between local climate and hydrology in a small Sphagnum mire in northern Poland: implications for ecosystem management and palaeohydrological studies. Polish Journal of Environmental Studies 19(4): 779-787.

Steinthorsdottir M, Wagner-cremer F and Steinthorsdottir M (2019) Hot summers ahead? Multidecadal spring season warming precedes sudden summer temperature rise in pre-anthropogenic climate change summer temperature rise in pre-anthropogenic climate change. GFF. Taylor \& Francis 00(00): 1-6. Available at: https://doi.org/10.1080/11035897.2019.1655791: doi:10.1080/11035897.20 19.1655791.

Tackeray S, Henrys P, Hemming D and Bell J (2016) Phenological sensitivity to climate across taxa and trophic levels. Nature 535: 241-245.

Tapiquén CEP (2020) Geografía, SIG y Cartografía Digital. Valencia, Spain,. Available at: http:// tapiquen-sig.jimdofree.com.

Team QD (2021) QGIS Geographic Information System. QGIS Association. Available at: https://www. qgis.org.

Thomas PW, Woodward FI and Quick WP (2004) Systemic irradiance signalling in tobacco. New Phytologist 161(1): 193-198: doi:10.1046/j.1469-8137.2003.00954.x.

Tichá I (1985) Ontogeny of Leaf Morphology and Anatomy. Photosynthesis during leaf development, 16-50.

Wagner-Cremer F, Donders TH and Visscher H (2010a) Drought stress signals in modern and subfossil Quercus laurifolia (Fagaceae) leaves reflect winter precipitation in southern Florida tied to El NiñoSouthern Oscillation activity. American Journal of Botany 97(5): 753-759: doi:10.3732/ajb.0900196.

Wagner-Cremer F, Finsinger W and Moberg A (2010b) Tracing growing degree-day changes in the cuticle morphology of Betula nana leaves: A new micro-phenological palaeo-proxy. Journal of Quaternary Science 25(6): 1008-1017: doi:10.1002/jqs.1388.

Wagner F (1998) The influence of environment on the stomatal frequency in Betula. LPP Contrib. Series 9: 1-102.

Wagner F, Visscher H, Kurschner WM and Dilcher DL (2007) Influence of ontogeny and atmospheric CO2 on stomata parameters of Osmunda regalis. Courier Forschungsinst. Senckenberg 258: 183-189. Available at: http://kbd.kew.org/kbd/detailedresult.do?id=379688.

Weijers S, Wagner-Cremer F, Sass-Klaassen U, Broekman R and Rozema J (2013) Reconstructing High Arctic growing season intensity from shoot length growth of a dwarf shrub. The Holocene 23(5): 721-731. Available at: http://journals.sagepub.com/doi/10.1177/0959683612470178: doi:10.1177/0959683612470178.

Wickham H (2016) ggplot2: Elegant Graphics for Data Analysis. New York: Springer-Verlag. Available at: http://ggplot2.org.

Zhang W, Jansson PE, Sigsgaard C, McConnell A, Jammet MM, Westergaard-Nielsen A, et al. (2019) Model-data fusion to assess year-round CO2 fluxes for an arctic heath ecosystem in West Greenland $\left(69^{\circ} \mathrm{N}\right)$. Agricultural and Forest Meteorology. Elsevier 272-273(July): 176-186. Available at: https:// doi.org/10.1016/j.agrformet.2019.02.021: doi:10.1016/j.agrformet.2019.02.021. 
Effects of experimental warming on Betula nana epidermal cell growth tested over its maximum climatological growth range 


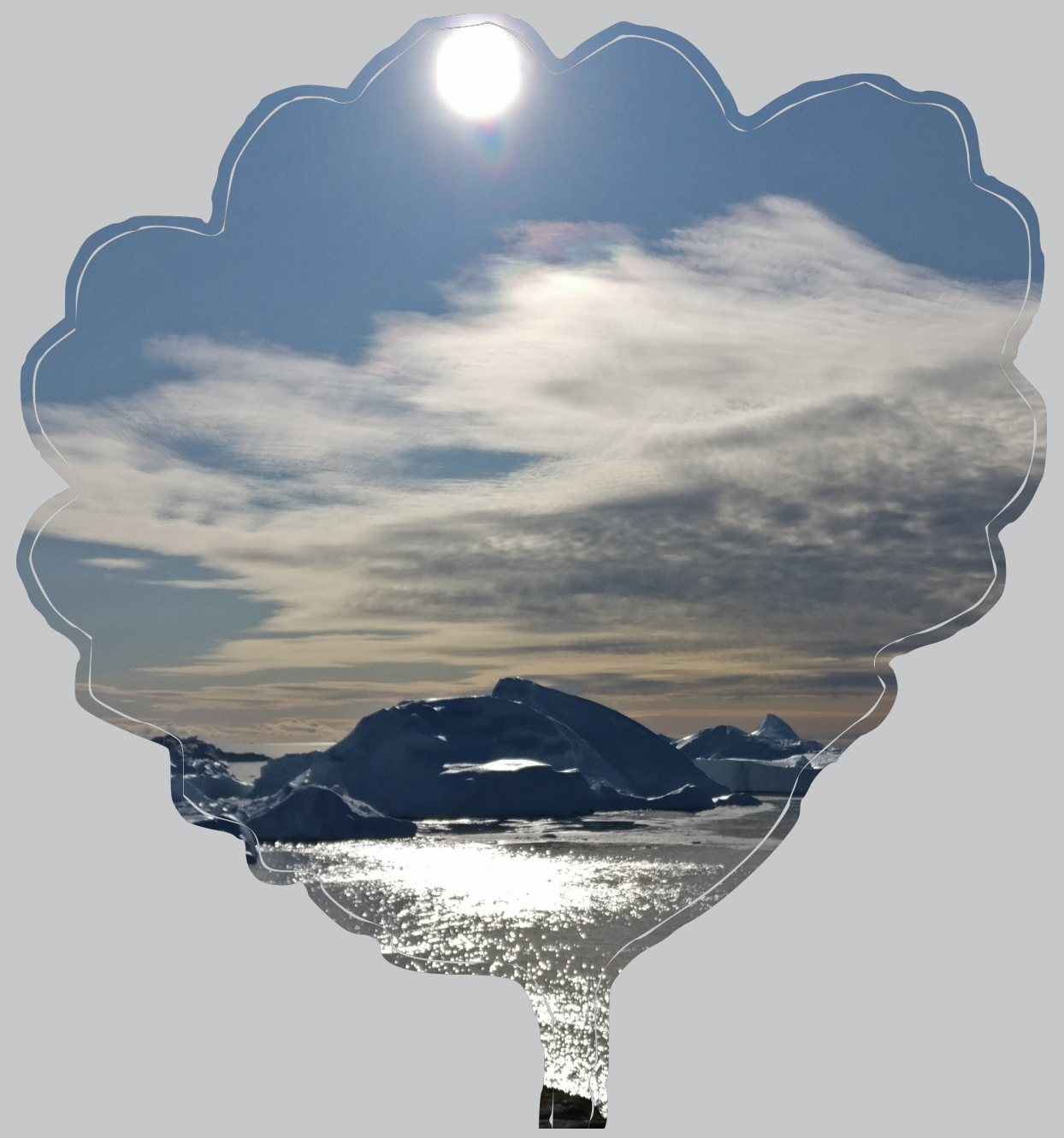




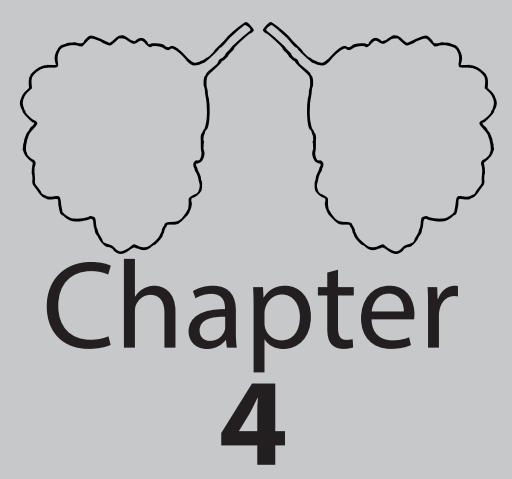




\title{
North Atlantic Oscillation seesaw effect in leaf morphological records from dwarf birch shrubs in Greenland and Finland
}

\author{
Fabian E.Z.Z. Ercan ${ }^{1} \mid$ Daan Blok $^{2} \mid$ StefWeijers ${ }^{3} \mid$ Astrid Odé $^{1} \mid$ Friederike Wagner- \\ Cremer \\ ${ }^{1}$ Palaeoecology, Department of Physical Geography, Utrecht University, Utrecht, The Netherlands \\ ${ }^{2}$ Dutch Research Council (NWO), Den Haag, The Netherlands. \\ ${ }^{3}$ Department of Geography, University of Bonn, Bonn, Germany
}

In print at Polar Research, 2021

\begin{tabular}{|l|}
\hline 4.1 Abstract \\
The North Atlantic Oscillation (NAO) determines wind speed and direction, \\
seasonal heat, moisture transport, storm tracks, cloudiness and sea-ice cover \\
through atmospheric mass balance shifts between the Arctic and the subtropical \\
Atlantic. The NAO is characterized by the typical, yet insufficiently understood, \\
seesaw pattern of warmer winter and spring temperatures over Scandinavia \\
and cooler temperatures over Greenland during the positive phase of the NAO, \\
and vice versa during the negative phase. We tested the potential to reconstruct \\
NAO variation beyond the meteorological record through the application of a \\
microphenological proxy. We measured the Undulation Index (UI) in Betula nana \\
epidermal cells from herbarium leaf samples and fossil peat fragments dating \\
back to $1865-$ exceeding most meteorological records in the Arctic-to estimate \\
imprints of spring thermal properties and NAO in Greenland and Finland. We found \\
negative relations between Greenland Ul and late winter, spring and early summer \\
NAO and mostly positive, but not significant, relations between Finland UI and \\
NAO in years with pronounced NAO expression. The direction of the UI response \\
in this common circumpolar species is therefore likely in line with the NAO seesaw \\
effect, with leaf development response to NAO fluctuations in northern Europe \\
opposing the response in Greenland, and vice versa. Increased knowledge of the \\
Ul response to climate may contribute to understanding ecological properties of \\
key Arctic species, while additionally providinga proxy for NAO dynamics.
\end{tabular}




\subsection{Introduction}

Cold season (October - May) warming in the Arctic is nearly three times stronger than in the remaining Northern hemisphere and is accompanied by a lengthening of the growing season through the advanced onset of spring (Bintanja et al., 2020; Box et al., 2019; IPCC, 2019). The main primary production in (sub-) Arctic tundra ecosystems is provided by typical low-growing shrubs including Betula, Cassiope, Salix, and Vaccinium species (Walker et al., 2005). Generally, Arctic vegetation is temperature limited by harsh winter conditions and short, and relatively cold growing seasons. A continuation of rapid warming during the cold season has the potential to release this temperature limitation, leading to structural alterations of the habitat through changes in local snow cover, hydrology, frost protection, permafrost dynamics and nutrient availability (Box et al., 2019; IPCC, 2019; Steinthorsdottir et al., 2019). A positive response of the vegetation such as earlier leaf-out and flowering dates is already evident in ground-based observational studies for individual species (Chmielewski \& Rotzer, 2001; Higgens et al., 2020; Wagner-Cremer et al., 2010; Weijers et al., 2017), as well as from remote sensing studies on ecosystem level phenology (Berner et al., 2020; Hobbie et al., 2017; Xu et al., 2013). Still, earlier onset of the phenological cycle also poses threats to the vegetation through increased vulnerability to late frost events (Francon et al., 2020; Weijers et al., 2018; Wipf et al., 2009).

The driving mechanism behind the regional winter and spring weather conditions that regulate northern latitude plant phenology is the North Atlantic Oscillation (NAO) (Cook et al., 2005; D'Odorico et al., 2002; Weijers et al., 2017). Induced by sea level pressure (SLP) differences, the NAO determines wind speed and direction, seasonal heat, moisture transport, storm tracks, cloudiness and sea ice cover through atmospheric mass balance shifts between the Arctic and the subtropical Atlantic (Hurrell et al., 2003; Young et al., 2012). Moreover, a strong correlation is known to exist between SLP and the prevailing surface air temperature in the adjacent terrestrial regions. The differences in SLP produce a typical, yet insufficiently understood, "seesaw" pattern of warmer winter and spring temperatures over Scandinavia and cooler temperatures over Greenland during the positive phase of the NAO, and vice versa during its negative phase (D'Odorico et al., 2002; Hurrell, 1995; Polyakov et al., 2003; van Loon \& Rogers, 1978).

Plant responses are thus likely related to the annual intensity of this winter and spring weather-determining atmospheric circulation system. Implementing 
biological indicators, such as plant traits that capture seasonal temperatures, can resolve local to regional plant responses, and therefore facilitate more accurate estimates of vegetation dynamics across the NAO-susceptible area. Many plant biological indicators that are available in the Arctic, however, are predominantly sensitive to summer temperatures (Park et al., 2019; Weijers et al., 2010). The sparse information on broader seasonal temperature regimes is currently obtained through tree ring-width analyses indicative for winter / spring dynamics (Hollesen et al., 2015; Sakashita et al., 2018) or shoot-length analyses of the Arctic dwarf shrub Cassiope tetragona, which has been shown to capture growing degree days (GDD) and Arctic/ North Atlantic Oscillation phase changes (Aanes et al., 2002; Weijers et al., 2013, 2017; Welker et al., 2005).

A quantifiable imprint of GDD and spring onset date is observed in the microscopic leaf morphology of the common (sub-)Arctic shrub Betula nana (Ercan et al., 2021; Steinthorsdottir et al., 2019; Wagner-Cremer et al., 2010). Time-series analysis of annually collected leaf samples from northern Finland revealed a strong correlation between Undulation Index (UI) and spring and summer temperatures, allowing for full maturation of leaves reaching maximum epidermal cell size during warm growing seasons, whereas cold growing seasons suppress the lateral epidermal cell expansion during the maturation process (Steinthorsdottir et al., 2019; Wagner-Cremer et al., 2010). The degree of cell maturation is thereby quantified as the UI, which is the ratio of cell circumference over cell area (Kürschner, 1997; Wagner-Cremer et al., 2010). This stimulation of cell expansion under increasing GDD has been confirmed in a spatial analysis of Betula pubescens leaves sampled over a large latitudinal gradient with significant differences in growth period and temperature, following a similar trend (Ercan et al., 2020).

In the present study we determined the UI of $B$. nana historical leaf samples from Disko Island, W-Greenland, retrieved from the herbarium collections of the Arctic Station and Copenhagen University. The Greenlandic site results are compared to UI measurements on sub-fossil B. nana leaves extracted from well-dated peat sections in Palomaa, northern Finland (Finsinger et al., 2013; Wagner-Cremer et al., 2010). The complementary localities provide leaf samples for the past 150 years and date back to the onset of anthropogenic warming (Fischer et al., 2018).

Based on these records, we made direct comparisons between the leaf epidermal cell UI, and relevant NAO indices to test the influence of NAO related thermal growing season variability on $B$. nana leaf properties. As UI captures the growing season

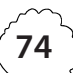


thermal sum and is largely dependent on spring temperatures, we hypothesize that the UI records reflect the winter/early-spring NAO mode and intensity at both localities, i.e., on Disko Island, W-Greenland and in northern Finland, in years with pronounced NAO-expression.

\subsection{Materials and Methods}

\subsubsection{Leaf Samples}

B. nana leaf specimens from the Disko area $\left(69^{\circ} 16^{\prime} \mathrm{N} 53^{\circ} 27^{\prime} \mathrm{W}, 110 \mathrm{~m}\right.$ asl, figure 4.1) were collected from the herbarium at Arctic Station, Qeqertarsuaq, and the Copenhagen Herbarium. From each preserved B. nana specimen, a minimum of 5 leaves were harvested. The oldest sample dates to 1865, while the most recent sample, from Disko, was sampled in Blæsedalen in 2017. The Disko dataset consisted of a total of 29 samples spanning 152 years. Subfossil B. nana leaves were retrieved from a well-dated peat section from a bog in Palomaa, Finland $\left(69^{\circ} 15^{\prime} \mathrm{N}\right.$, $27^{\circ} 14^{\prime} \mathrm{E}, 179 \mathrm{~m}$ asl, Fig. 4.1), yielding 36 samples for the 69-year period 1933-2002. The longer Palomaa time series data were cut-off at 1933 due to the increasing age-uncertainty in the older section of the peat core (Finsinger et al., 2013). In figure $\mathbf{4 . 2} \mathbf{a}$ and $\mathbf{b}$, the source material is shown.

From the Disko herbarium specimen, $0.5 \times 0.5 \mathrm{~cm}$ sections from the central part of individual leaves were bleached in sodium hypochlorite $(<5 \%)$ at room temperature for 12-24 h. From each sample, 3 leaves were used. For each of the Palomaa samples, several leaf fragments of the same size $\left(1 \mathrm{~cm}^{2}\right)$ were used (Finsinger et al., 2013).

The cuticle bearing epidermis was subsequently removed with tweezers and stained with safranin. Five digital photographs of each cuticle bearing epidermis peel were taken using a Leica (Wetzlar, Germany) Quantimet 500 C/500+ light microscope using AnalySIS image analysis software (AnalySIS auto 5.1) at 1000x magnification. In figure $4.2 \mathbf{c}$ and $\mathbf{d}$, examples of typical epidermal cell images are shown. Analyses of epidermal cell properties were performed using ImageJ 1.52a. 


\section{Chapter 4}

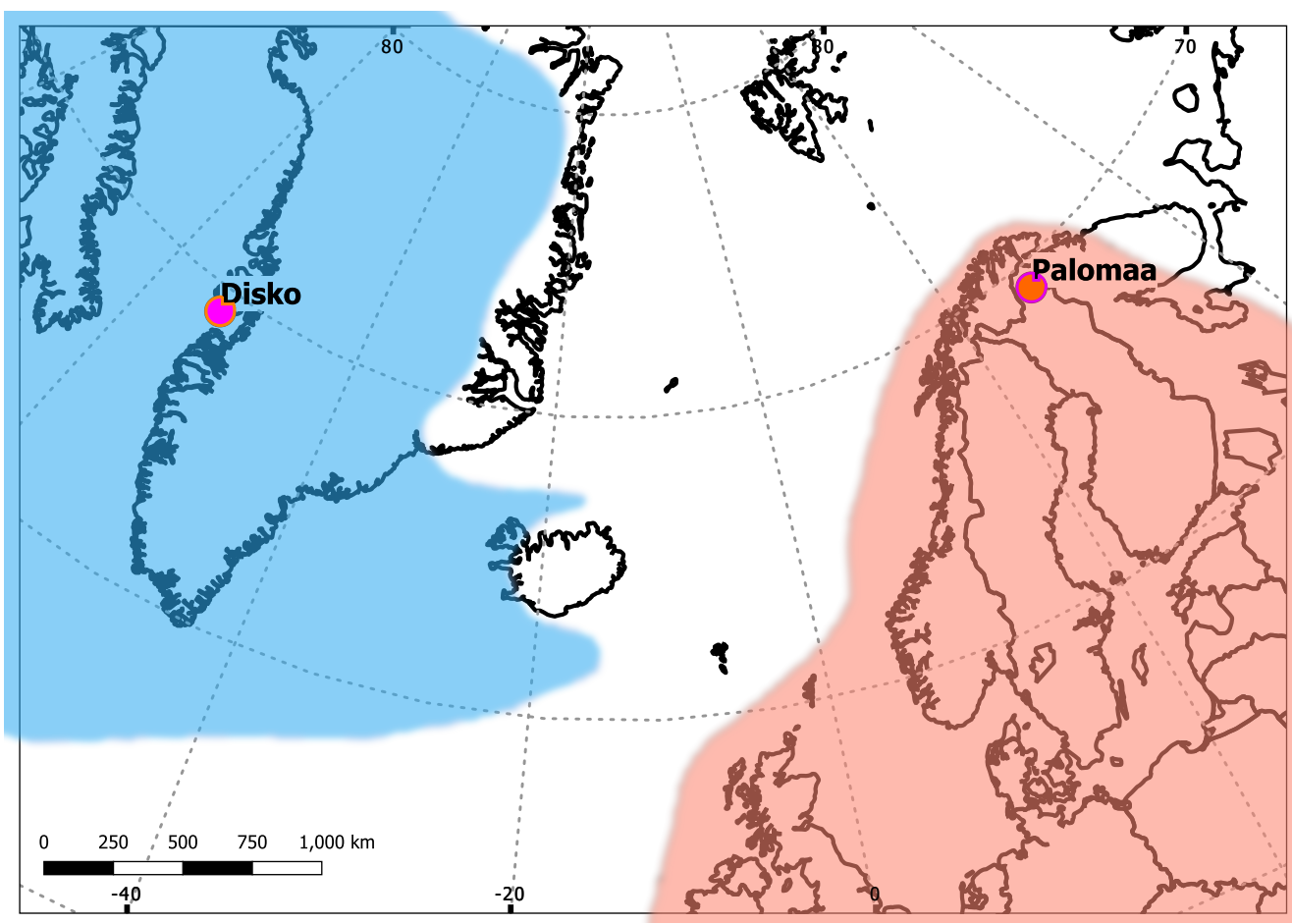

Figure 4.1: Locations of the study sites, Disko Island, Greenland and Palomaa, Finland on a map of the northeast Atlantic region, indicating areas of positive (red shades) and negative (blue shades) correlation of local air temperature with winter (DJF) NAO index [Hurrel, 1995] values. Based on and adapted from Hanna \& Cropper, 2017; Marcos et al., 2016; Visbeck et al., 2001. Compiled using QGIS (QGIS Development Team, 2021) and a shape downloaded from http://tapiquen-sig.jimdofree.com. Carlos Efraín Porto Tapiquén. Geografía, SIG y Cartografía Digital. Valencia, Spain, 2020. 


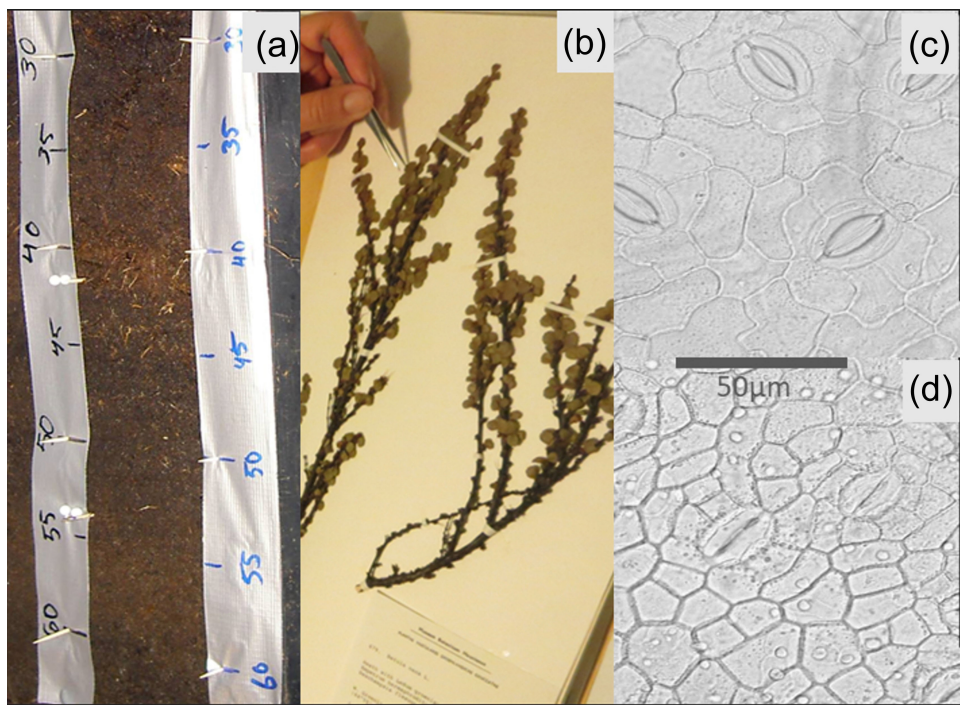

Figure 4.2: (a) part of the original peat core taken at Palomaa (30-60 cm depth), (b) representative $B$. nana herbarium specimen from Disko Island, (c) microscopic image of a B. nana epidermal cells from Palomaa with high UI, (d) epidermal cell image with low UI typical for Greenland.

\subsubsection{Calculation of the UI}

To estimate themeanepidermalcellarea, $C A\left(\mu \mathrm{m}^{2}\right)$, and epidermalcell circumference, $C C(\mu \mathrm{m}), 30$ random pavement cells per sample were analysed, avoiding cells over venation and leaf margins. From CA and CC, the UI (dimensionless) of the epidermal cell wall was calculated. UI (Equation 4.1) indicates the relation between cell circumference and cell area representing the sinuosity of the epidermis cell wall (Kürschner, 1997).

$$
U I[\text { dimensionless }]=\frac{C C}{2 \pi \cdot \sqrt{C A / \pi}}
$$

[Equation 4.1]

\subsubsection{Climate data}

To verify the reactiveness of local weather to NAO index fluctuations, temperature anomalies for the corresponding grid for each site were retrieved via the KNMI Climate Explorer (Trouet \& Van Oldenborgh, 2013) from the gridded dataset of the Berkeley Earth Surface Temperature Project (Rohde et al., 2013) . For Disko, the $1^{\circ}$ grid formed by longitudes -54 to $-53^{\circ} \mathrm{E}$ and latitudes 69 to $70^{\circ} \mathrm{N}$ was used, and for 
Palomaa, the grid formed by longitudes 27 to $28^{\circ} \mathrm{E}$ and latitudes 69 to $70{ }^{\circ} \mathrm{N}$. To compare the NAO index to the UI, two definitions of the NAO index were retrieved via the KNMI Climate Explorer. The first one (NAO-1) is defined as the difference in atmospheric pressure measured between Gibraltar (southernmost Iberia) and Stykkisholmur (Iceland) recorded from 1821 onwards, while the second one (NAO2) represents the difference in atmospheric pressure measured between the Azores and Stykkisholmur, recorded from 1865-2002 (Jones et al., 1997). These two indices are highly correlated $(r=0.78, p<0.001)$ and allow expression of the NAO results using either of them with confidence.

From the temperature anomaly data and NAO index data, different subsets were isolated to capture dynamics from different parts of the year, potentially relevant for year-to-year differences in plant development. The monthly values were averaged for sets of several months that are indicative of: NDJF (November, December, January, February) the winter preceding the growing season, FMA (February, March, and April) the late winter, early spring, AM (April, May) the Arctic spring, and MJJ (May, June, July) the Arctic summer.

\subsubsection{Filter}

To prevent years with a weak temperature anomaly, NAO index, or a too-low (immature) UI response from distorting the interpretation of the interactions between UI and NAO, a high-pass filter was used. The used cut-off value was one half of the standard deviation of the UI values (z-scored, to centre values around 0 , for comparison with index values) and each of the temperature anomaly and NAO index values, both in the positive and negative directions. In some cases, NAO-1 was left in the selection, where NAO-2 was cut off, and vice versa, because either of the index values was not pronounced enough to be greater than the related filter value. This resulted in some instances in which only one of the two index versions was represented in the comparisons. If no filter was used on the data for a specific correlation, it is explicitly mentioned below.

\subsubsection{Statistics}

All filtering, statistics and graph production were performed using R 4.0 (R Core Team, 2020). Pearson's correlation tests were used to check for significant $(p<0.05)$ associations between subsets of the localised temperature anomalies and corresponding subsets of NAO signals, and between the corresponding subsets of NAO signals and z-scored UI data. 


\subsection{Results}

Analysis of B. nana leaf material from Disko (1865-2017) and Palomaa (1933-2002) on UI yielded 29 datapoints for Disko and 35 for Palomaa (Figure 4.3). The mean value of the Disko UI was 1.18 (min: 1.13, max: 1.21, $\sigma=0.2$ ), and 1.24 (min: 1.15, max: $1.34, \sigma=0.04$ ) for Palomaa, indicating greater $B$. nana leaf cell expansion at the latter site. The overall range of the Palomaa UI values was higher, more variable, and averaged above the mean UI measured on Disko leaf samples. The Disko dataset showed a narrower range of UI values with maximum values in the lower range of Palomaa UI values. A direct comparison between the UI records from Disko and Palomaa could not be made, because of a lack of sufficient overlapping years.

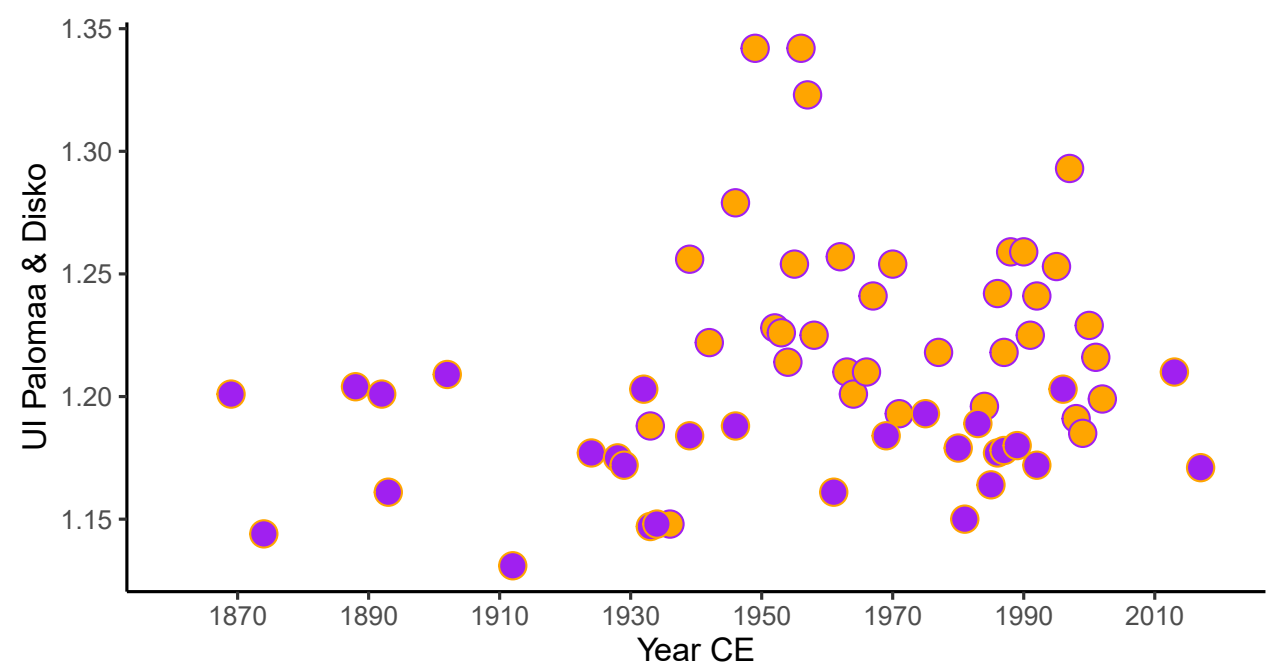

Figure 4.3: Mean UI-values for B. nana herbarium samples from Disko (purple marks) and Palomaa (orange marks) for the individual years studied.

In the comparison between the local temperature anomalies and NAO index data for the years for which we also have UI data, statistically significant correlations were found between most of the subsets (Table 4.1). From all the correlations between subsets of temperature anomalies from both locations with both NAO indices, all directions of correlations indicated a negative relation between the NAO and temperature on Disko and a positive relation between the NAO and temperature in Palomaa. The only non-significant relations found were those between NAO$2_{\text {MJ', }}$ NAO- $1_{\mathrm{AM}^{\prime}}$ NAO- $2_{\text {AM }}$ and the corresponding temperature anomalies from Disko 
and the one between NAO-1 ${ }_{A M}$ and the corresponding temperature anomaly from Palomaa.

Table 4.1: Correlation coefficients $(r)$ between subsets of temperature anomaly values from Disko, Greenland, and Palomaa, Finland, against corresponding subsets of the NAO indices. All data are filtered with high-pass criteria unless indicated. ${ }^{\mathrm{a}} p \leq 0.001 .{ }^{\mathrm{b}} p \leq 0.01 .{ }^{\mathrm{c}} p \leq 0.05 .{ }^{\mathrm{d}} p>0.05$.

\begin{tabular}{|c|c|c|}
\hline$r$ & $\begin{array}{l}\text { Temp. anomaly } \\
\text { (subset) Disko } \\
\text { 1865-2017 (n) }\end{array}$ & $\begin{array}{l}\text { Temp. anomaly } \\
\text { (subset) Palomaa } \\
1933-2002(n)\end{array}$ \\
\hline NAO-1 ${ }_{\text {no-filter }}$ & $-0.49^{\circ}(148)$ & $+0.36^{a}(175)$ \\
\hline NAO-2 ${ }_{\text {no-filter }}$ & -0.44 a (131) & $+0.55^{\mathrm{a}}(143)$ \\
\hline NAO-1 ${ }_{\text {NDJF }}$ & -0.35 a (149) & $+0.40^{a}(176)$ \\
\hline NAO-2 ${ }_{\text {NDJF }}$ & -0.38 a (132) & $+0.26^{a}(143)$ \\
\hline NAO-1 ${ }_{\mathrm{FMA}}$ & -0.30 a (149) & $+0.25^{\circ}(176)$ \\
\hline NAO-2 ${ }_{\mathrm{FMA}}$ & -0.42 a (132) & $+0.39^{a}(144)$ \\
\hline NAO-1 ${ }_{\text {AM }}$ & $-0.07^{d}(149)$ & $+0.11^{d}(176)$ \\
\hline NAO-2 ${ }_{\text {AM }}$ & $-0.06^{d}(132)$ & $+0.19^{c}(144)$ \\
\hline NAO-1 ${ }_{\text {MJJ }}$ & $-0.18^{c}(149)$ & $+0.16^{c}(176)$ \\
\hline NAO-2 & $-0.06^{b}(132)$ & $+0.27^{b}(144)$ \\
\hline
\end{tabular}

In a comparison between z-scored and filtered B. nana UI data from Disko (18652017) and Palomaa (1933-2002) and several subsets of filtered NAO-1 and NAO-2 index values, the direction and relevance of deviation from the mean value were tested (Table 4.2). As the majority of UI datapoints from Disko are in antiphase with $\mathrm{NAO}$, the correlation is negative in direction, whereas the majority of UI datapoints from Palomaa are in phase with the NAO indices, indicating an opposite response. Statistically significant correlations were determined for the subset average of the months FMA, (NAO- $1_{\text {FMA }}$ vs. Disko UI: $r=-0.63, p<\leq .05$, figure 4.4), AM (NAO- $2_{\text {AM }}$ vs. Disko UI: $r=-0.67, p \leq .05)$ and for MJJ (NAO- $2_{\text {MJ }}$ vs. Disko UI: $r=-0.76, p \leq .05$; see table 4.2). None of the Palomaa relations were significant. NAO-1. In figure 4.5, the interaction between NAO- $1_{\mathrm{NDJF}}$ and filtered z-scored Palomaa UI data is shown, mostly in-phase with each other, however not significantly. 


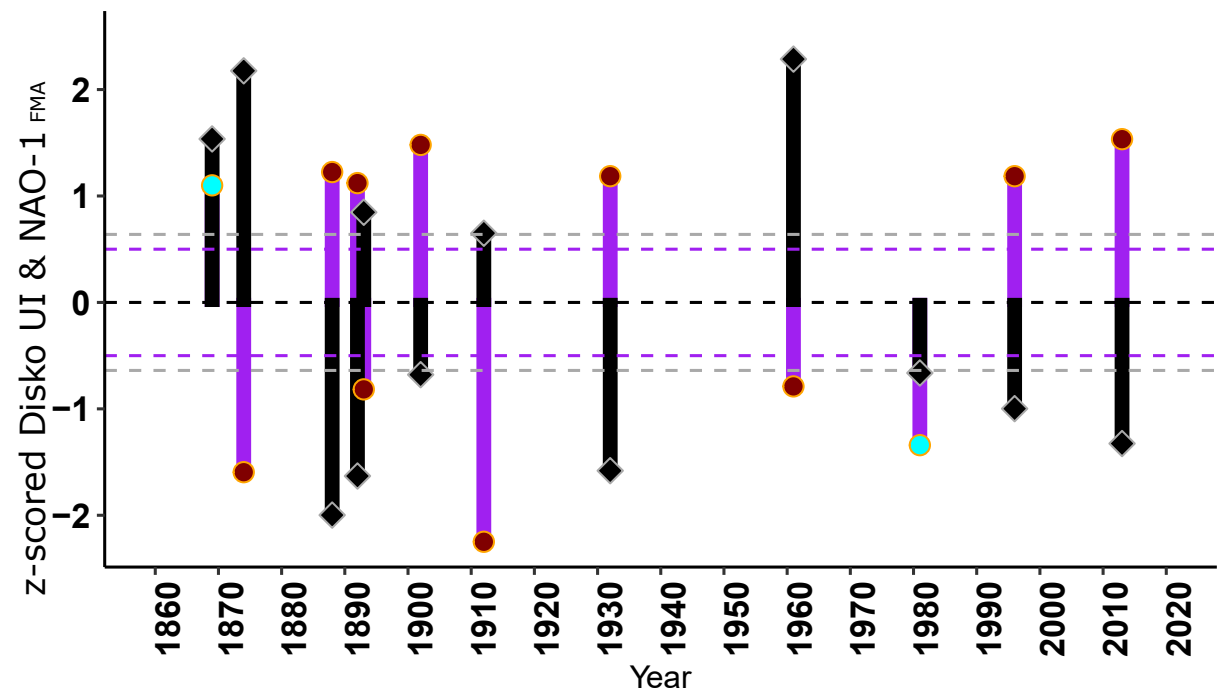

Figure 4.4: Z-scored UI data from Betula nana herbarium samples (dots) from Disko and NAO- $1_{\mathrm{FMA}}$ index (black diamonds and bars) for each of the corresponding years (1865-2017). Blue UI dots indicate when $\mathrm{UI}$ follows NAO, red dots indicate when they oppose in direction. Dotted lines indicate cut-off points based on 0.5 standard deviation (purple $=\mathrm{UI}$ data, grey $=$ NAO- $1_{\text {FMA }}$ ). NAO- $1_{\text {FMA }}$ versus Disko Ul: $r=-0.63, p<0.05$. Note that 10 out of $12 \mathrm{UI}$ data points oppose the NAO in direction.

Table 4.2: Correlation coefficients ( $r$ ) between Betula nana UI values from Disko, Greenland, and Palomaa, Finland, against several subsets of the NAO indices. All data are filtered with high-pass criteria unless indicated. ${ }^{\mathrm{a}} p \leq 0.05 .{ }^{\mathrm{b}} p>0.05$.

\begin{tabular}{|c|c|c|}
\hline $\boldsymbol{r}$ & \begin{tabular}{|l|} 
UI Disko \\
$1865-2017$ (n)
\end{tabular} & \begin{tabular}{|l|} 
UI Palomaa \\
$1933-2002(n)$
\end{tabular} \\
\hline NAO-1 ${ }_{\text {no-filter }}$ & $-0.21^{b}(29)$ & $+0.10^{\mathrm{b}}(42)$ \\
\hline NAO-2 ${ }_{\text {no-filter }}$ & $-0.32^{b}(27)$ & $-0.04^{\mathrm{b}}(41)$ \\
\hline NAO-1 ${ }_{\text {NDJF }}$ & $-0.28^{b}(10)$ & $+0.33^{b}(10)$ \\
\hline NAO-2 ${ }_{\text {NDJF }}$ & $-0.16^{b}(10)$ & $+0.12^{\mathrm{b}}(12)$ \\
\hline NAO-1 ${ }_{\mathrm{FMA}}$ & $-0.63^{a}(12)$ & $+0.25^{\mathrm{b}}(12)$ \\
\hline NAO-2 $2_{\text {FMA }}$ & $-0.44^{b}(8)$ & $+0.21^{\mathrm{b}}(13)$ \\
\hline $\mathrm{NAO} \mathbf{1}_{\mathrm{AM}}$ & $-0.31^{b}(10)$ & $+0.20^{b}(14)$ \\
\hline NAO-2 ${ }_{\text {AM }}$ & -0.67 a (13) & $-0.03^{b}(10)$ \\
\hline NAO-1 & $+0.20^{b}(11)$ & $+0.14^{b}(10)$ \\
\hline NAO-2 & $-0.76^{a}(10)$ & $-0.44^{b}(12)$ \\
\hline
\end{tabular}




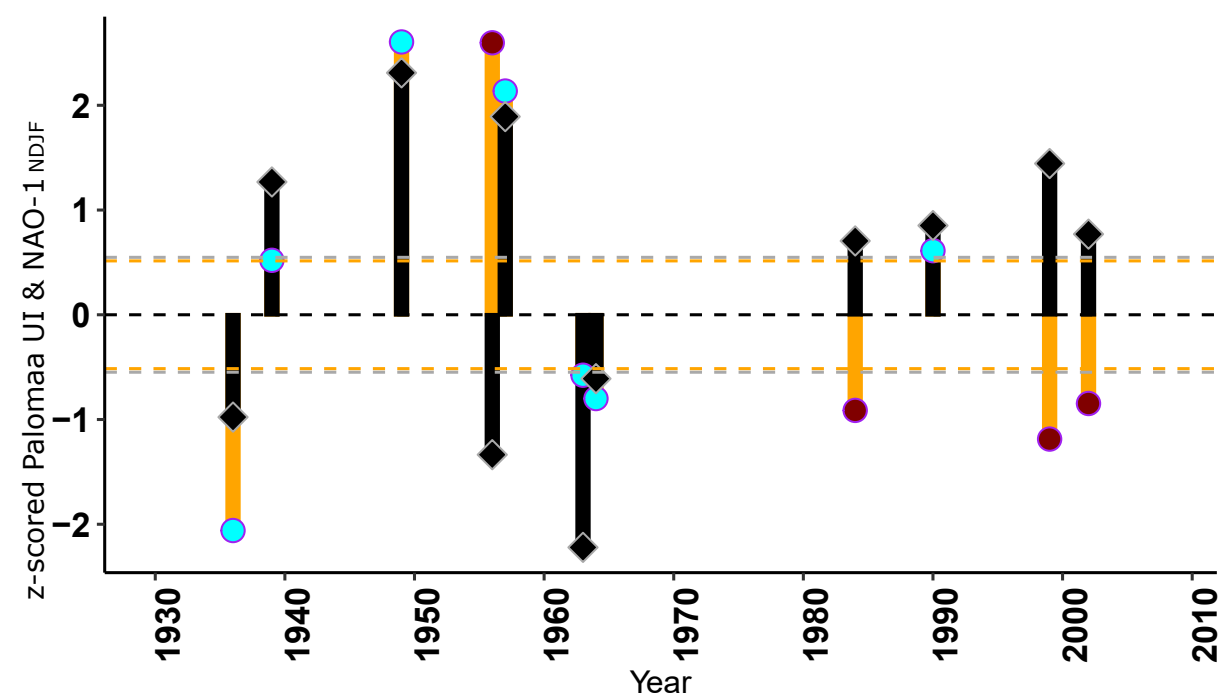

Figure 4.5: Z-scored UI data from Betula nana herbarium samples (blue or purple dots) from Palomaa and NAO-1 $1_{\text {NDJF }}$ index (black diamonds and bars) for each of the corresponding years (1933-2002). Blue UI dots indicate when UI follows NAO, purple dots indicate when they oppose in direction. Dotted lines indicate cut-off points based on 0.5 standard deviation (orange $=\mathrm{UI}$ data, grey $=\mathrm{NAO}-1_{\mathrm{NDF}}$ ). NAO- $1_{\text {NDJF }}$ versus Palomaa UI: $r=0.33, p>0.05$. Note that seven out of $11 \mathrm{UI}$ data points follow the NAO in direction.

\subsection{Discussion}

The two UI data sets from the contrasting localities on Disko and Palomaa revealed some differences. While the UI values of Disko samples varied between 1.13 and 1.21 , the Palomaa samples reached higher degrees of cell wall undulation with $\mathrm{UI}$ values up to 1.34 , with only a few samples falling within the range of Disko UI levels (Figure 4.3). The discrepancy between the overall ranges is related to the contrasting temperature regimes prevailing at the two sites. Annual temperature and GDD, quantifying the thermal sum during the growing season, at Disko are far lower than at Palomaa and thus lead to suboptimal growth conditions, hampering leaf maturation (Wagner-Cremer et al., 2010). Palomaa, on the contrary, is characterized by a more favourable climate enabling full leaf maturation (Finsinger et al., 2013). Generally, the climate of the Disko area is more oceanic, with relatively mild winters and cool summers, while the climate at Palomaa is more continental, with cold winters, but warm summers. 
Despite the general differences between the data from Palomaa and Disko presented here, both time series revealed systematic fluctuations related to the local growth conditions prevailing at the individual sites. Local temperature conditions during winter and the early growing season are closely linked to the prevailing sea level pressure and the intensity of the NAO, which is quantified by indices based on sea level pressure differences (Polyakov et al., 2003). A comparison of local temperature anomalies from the gridded Berkeley dataset with corresponding sub-sets of the NAO indices (Table 4.1), confirmed the strong and significant relationship between local temperatures and the NAO, mainly in winter (NDJF and FMA). As the dominant factor for weather in the studied regions, the NAO also governs wind, humidity, and cloudiness conditions (Hurrell et al., 2003; Young et al., 2012), thereby acting on adverse or beneficial weather traits, which can directly affect plant performance in terms of growth and development.

Most relations between Disko UI and NAO subsets were negative, whilst most relations between Palomaa UI and NAO subsets were positive (Table 4.2), in accordance with the "seesaw" characteristic of the NAO and its temperature influence. The most significant correlations were observed for the subset average of the months FMA, NAO-1 figure 4.3), AM NAO-2 and for MJJ NAO-2, see table 4.2. However, the MJJ correlation with Disko UI was ambiguous, as correlations with NAO-1 and NAO-2 gave mixed results regarding the direction of the relation, although the unexpected positive correlation with NAO-1 was not significant. The winter and early growing season are important, as plant performance is very sensitive to late winter/early spring variability, especially in the Arctic (Flynn \& Wolkovich, 2018; Li et al., 2016). Moreover, the NAO has its main influence on local weather conditions in winter / early spring (Cook et al., 2002; Hurrell, 1995). Still, NAO has some influence on weather even during the MJJ part of the year (Hurrell, 1995), as is also evident in the correlations between local temperature anomalies and NAO indices (Table 4.1).

Although none of the Palomaa UI - NAO correlations were significant, most of the interactions between sub-sets were in-phase with NAO (see for example Figure 4.5), agreeing with the expected influence of NAO in northern Finland. The low number of significant correlations between $\mathrm{UI}$ and NAO indices might be attributed to the low number of datapoints that passed the filter criteria, a result caused by the low number of total samples. Also, as the NAO has less influence in northern Finland (Uvo, 2003), it might account for the lesser impact on UI there. Nevertheless, we found relevant and significant relations between Palomaa temperature anomalies 
and both NAO-1 and NAO-2. Although the indices quantify the NAO differently, they still represent the same meteorological phenomenon.

The UI, indicating different levels of maturity of the Disko samples, was more profoundly affected by NAO dynamics than the UI in Palomaa. This difference in the UI between NAO phases implies that the release of stress, for example, through higher late winter or early growing season temperatures, or other favourable weather conditions on Disko Island during a negative NAO phase, is beneficial for the maturation of $B$. nana leaves in this extreme environment. In contrast, a positive NAO phase and accompanying unfavourable weather conditions have an adverse effect on the UI. Under the overall more favourable growth conditions in Finland, which experiences much warmer growing seasons due to its continental climate, additional stress release during the early growing season produces a detectable signal in the leaf morphology, quantified as UI, while the final maturation of B. nana leaves is regulated through the length of the growing season by accumulating thermal sum totals (Steinthorsdottir et al., 2019; Wagner-Cremer et al., 2010). Despite the differences in signal intensity, our data show that the direction of response (positive or negative correlation) is likely opposite in the two contrasting sites which is in line with the bipolar character of the NAO (Polyakov et al., 2003; van Loon \& Rogers, 1978). The responsiveness of the UI of $B$. nana leaf remains from herbarium and subfossil records to alterations in the NAO suggests that this morphological trait is sensitive to this large-scale atmospheric system.

Effects of NAO dynamics on Arctic shrubs have also been observed for the circumarctic evergreen dwarf shrub Cassiope tetragona. Annual shoot increment of this species correlates with NAO driven temperature regimes (Rayback \& Henry, 2006; Weijers et al., 2017). In Greenland, a significant negative correlation between shoot length indices and the NAO (June, July with $r=-0.39, p<.01, r=$ $-0.26, p<.05$, respectively) occurs in Johannes $\mathrm{V}$. Jensen Land, the northernmost region of Greenland (Weijers et al., 2017). In the remote settings of this location, the cumulative warmth of the growing season is received in late June and July. However, the negative correlation with the October Arctic Oscillation (AO) index of the previous year suggests that winter conditions there also play a regulating role, potentially through sea ice feedback and from the llullisat iceberg on summer temperatures (Buchwal et al., 2020; Koenigk et al., 2016; Wang \& Ikeda, 2000; Weijers et al., 2017). The results of the present study provide more direct evidence for the relevance of weather conditions (Table 4.1) during winter and spring months for the growth of (sub-) Arctic shrubs such as B. nana (Table 4.2). Our findings support 
those of an earlier B. nana shrub ring-width based study from Disko where time series analysis over the past century has shown that, besides growing degree days, winter and spring conditions play an important role for the growth performance of this species (Hollesen et al., 2015). Especially important for late winter and early spring dynamics are the mechanics surrounding soil thaw, affecting water and nutrient access, enabling or impeding plant growth.

The addition of the UI to NAO-sensitive proxies is highly relevant for seasonal climate reconstructions, as the effect of combining several proxy datasets has the potential to improve NAO reconstructions (Schmutz et al., 2000). Combining noninstrumental based proxies generally results in more robust reconstructions, and by combining them with instrumental data the best results are achieved (Cullen et al., 2001). Also, plant-based proxies for NAO signals may be more suitable than proxies for an individual climate parameter, since NAO incorporates multiple parameters such as temperature, precipitation and cloudiness, all potentially affecting plant performance, therefore representing a more complete signal (Weijers et al., 2017). Accordingly, the reaction of UI to NAO, as a (micro-) morphological response to a large-scale atmospheric climate system, is additional confirmation of the direct ecological importance of NAO fluctuations (Ottersen et al., 2001).

\subsubsection{Proxy relevance}

The UI was conceptually shown to be a NAO indicator in this study; it raises new opportunities in terms of further research on NAO spring dynamics through time, especially with the future availability of larger datasets. In the recent past, biological proxies in the Arctic and alpine tundra biome mainly revolved around dendrochronological shrub studies, but the UI can provide additional insight into NAO fluctuations in the NAO influenced areas beyond and above the treeline. This would mainly be the case in the (sub-) Arctic regions of Europe and North America, such as the areas where the leaf material studied in this research originated from. Also, when treelines shift through time as climate changes (Kruse et al., 2016), a tundra shrub-based proxy could aid in providing more continuous records. However, as the exact onset of the NAO is uncertain (Vinther et al., 2003), the UI proxy could still account for opposing or antiphase signals from both sides of the Atlantic. This additional potential for reconstruction will allow for increased cross-validation between areas for which previously no proxy NAO-records exist, and for areas with known proxy NAO-records. In particular, this enables NAOreconstructions that exceed current meteorological records. The addition of the 
spring-sensitive UI proxy to NAO-related discussions, such as episodes of historical climatic changes like the Medieval Warm Period, or the transition into the Little Ice Age, would be very welcome as these events have been suggested to be related to NAO phase changes (Young et al., 2015).

\subsection{Conclusions}

The opposite responses of UI in Finland and Greenland support our main hypothesis that lateral epidermal cell expansion in B. nana leaves depends in part on NAOdetermined winter and spring meteorological conditions, although the findings from Finland did not prove to be significant. Additionally, our results suggest that the characteristic'seesaw' relation between the opposing extreme ends in the NAO susceptible region is directly reflected in plant growth. During winter (NDJF) and late winter / early spring (FMA), the UI from Palomaa, Finland reacted positively to a positive NAO phase, while the UI from Disko, Greenland reacted negatively, and vice versa. This suggests that the NAO impacts local plant performance in terms of leaf development, as imprinted in the UI, according to the characteristic NAO seesaw pattern prevalent in the Northern Atlantic region. The use of the UI derived from herbaria and natural archives such as peat bogs and lake sediments as NAO proxies may increase our understanding of NAO dynamics over the past centuries and help to quantify the future impact of the NAO on plant performance and ecology.

\subsection{Acknowledgements}

We greatly appreciate the friendly support and permission to sample leaf specimens of the Arctic Station herbarium (Qeqertarsuaq, Greenland) and the Herbarium C (Natural History Museum of Denmark). 


\subsection{Literature}

Aanes, R., Sæther, B. E., Smith, F. M., Cooper, E. J., Wookey, P. A., \& Areøritsland, N. (2002). The Arctic Oscillation predicts effects of climate change in two trophic levels in a high-arctic ecosystem. Ecology Letters, 5(3), 445-453. https://doi.org/10.1046/j.1461-0248.2002.00340.x

Berner, L. T., Massey, R., Jantz, P., Forbes, B. C., Macias-Fauria, M., Myers-Smith, I., Kumpula, T., Gauthier, G., Andreu-Hayles, L., Gaglioti, B. V., Burns, P., Zetterberg, P., D’Arrigo, R., \& Goetz, S. J. (2020). Summer warming explains widespread but not uniform greening in the Arctic tundra biome. Nature Communications, 11(1), 1-12. https://doi.org/10.1038/s41467-020-18479-5

Bintanja, R., Wiel, K. Van Der, Linden, E. C. Van Der, Reusen, J., \& Bogerd, L. (2020). Strong future increases in Arctic precipitation variability linked to poleward moisture transport. February, 1-7.

Box, J. E., Colgan, W. T., Christensen, T. R., Schmidt, N. M., Lund, M., Parmentier, F. J. W., Brown, R., Bhatt, U. S., Euskirchen, E. S., Romanovsky, V. E., Walsh, J. E., Overland, J. E., Wang, M., Corell, R. W., Meier, W. N., Wouters, B., Mernild, S., Mård, J., Pawlak, J., \& Olsen, M. S. (2019). Key indicators of Arctic climate change: 1971-2017. Environmental Research Letters, 14(4). https://doi.org/10.1088/1748-9326/ aafc $1 b$

Buchwal, A., Sullivan, P. F., Macias-Fauria, M., Post, E., Myers-Smith, I. H., Stroeve, J. C., Blok, D., Tape, K. D., Forbes, B. C., Ropars, P., Lévesque, E., Elberling, B., Angers-Blondin, S., Boyle, J. S., Boudreau, S., Boulanger-Lapointe, N., Gamm, C., Hallinger, M., Rachlewicz, G., ... Welker, J. M. (2020). Divergence of Arctic shrub growth associated with sea ice decline. Proceedings of the National Academy of Sciences, 117(52), 33334-33344. https://doi.org/10.1073/pnas.2013311117

Chmielewski, F. M., \& Rotzer, T. (2001). Response of tree phenology to climate change across Europe. Agricultural and Forest Meteorology, 108(2), 101-112. https://doi.org/10.1016/S0168-1923(01)002337

Cook, B. I., Smith, T. M., \& Mann, M. E. (2005). The North Atlantic Oscillation and regional phenology prediction over Europe. Global Change Biology, 11(6), 919-926. https://doi.org/10.1111/j.13652486.2005.00960.x

Cook, E. R., D'Arrigo, R. D., \& Mann, M. E. (2002). A well-verified, multiproxy reconstruction of the winter North Atlantic Oscillation index since A.D. 1400. Journal of Climate, 15(13), 1754-1764. https:// doi.org/10.1175/1520-0442(2002)015<1754:AWVMRO>2.0.CO;2

Cullen, H. M., D'Arrigo, R. D., Cook, E. R., \& Mann, M. E. (2001). Multiproxy reconstructions of the North Atlantic oscillation. Paleoceanography, 16(1), 27-39. https://doi.org/10.1029/1999PA000434

D'Odorico, P., Yoo, J. C., \& Jaeger, S. (2002). Changing seasons: An effect of the North Atlantic Oscillation? Journal of Climate, 15(4), 435-445. https://doi.org/10.1175/1520-0442(2002)015<0435:CSAEOT>2.0 . $\mathrm{CO} ; 2$

Ercan, F. E. Z., De Boer, H. J., \& Wagner-Cremer, F. (2020). A growing degree day inference model based on mountain birch leaf cuticle analysis over a latitudinal gradient in Fennoscandia. Holocene, 30(2), 344-349. https://doi.org/10.1177/0959683619865605

Ercan, F. E. Z., Mikola, J., Silfver, T., Myller, K., Vainio, E., Słowińska S, Słowiński M, Lamentowicz M, Blok D \& Wagner-Cremer F (2021). Effects of experimental warming on Betula nana epidermal cell growth tested over its maximum climatological growth range. PLoS ONE, 16(5), 1-12. 
https://doi.org/10.1371/journal.pone.0251625

Finsinger, W., Schoning, K., Hicks, S., Lücke, A., Goslar, T., Wagner-Cremer, F., \& Hyyppä, H. (2013). Climate change during the past 1000 years: A high-temporal-resolution multiproxy record from a mire in northern Finland. Journal of Quaternary Science, 28(2), 152-164. https://doi.org/10.1002/ jqs. 2598

Fischer, H., Meissner, K. J., Mix, A. C., Abram, N. J., Austermann, J., Brovkin, V., Capron, E., Colombaroli, D., Daniau, A., Dyez, K. A., Felis, T., Finkelstein, S. A., Jaccard, S. L., McClymont, E. L., Rovere, A., Sutter, J., Wolff, E. W., Affolter, S., Bakker, P., ... Zhou, L. (2018). Palaeoclimate constraints on the impact of 2 ${ }^{\circ} \mathrm{C}$ anthropogenic warming and beyond. Nature Geoscience, 11(7), 474-485. https://doi.org/10.1038/ s41561-018-0146-0

Flynn, D. F. B., \& Wolkovich, E. M. (2018). Temperature and photoperiod drive spring phenology across all species in a temperate forest community. New Phytologist, 219(4), 1353-1362. https://doi. org/10.1111/nph.15232

Francon, L., Corona, C., Till-Bottraud, I., Choler, P., Carlson, B. Z., Charrier, G., Améglio, T., Morin, S., Eckert, N., Roussel, E., Lopez-Saez, J., \& Stoffel, M. (2020). Assessing the effects of earlier snow melt-out on alpine shrub growth:The sooner the better? Ecological Indicators, 115(October 2019). https://doi. org/10.1016/j.ecolind.2020.106455

Hanna, E., \& Cropper, T. E. (2017). North Atlantic Oscillation. In Oxford Research Encyclopedia of Climate Science (Issue January, pp. 536-539). Oxford University Press. https://doi.org/10.1093/ acrefore/9780190228620.013.22

Higgens, R.F., Pries, C.H. \& Virginia, R. A. (2020). Trade-offs Between Wood and Leaf Production in Arctic Shrubs Along a Temperature and Moisture Gradient in West Greenland. Ecosystems. https:// doi.org/https://doi.org/10.1007/s10021-020-00541-4

Hobbie, J. E., Shaver, G. R., Rastetter, E. B., Cherry, J. E., Goetz, S. J., Guay, K. C., Gould, W. A., \& Kling, G. W. (2017). Ecosystem responses to climate change at a Low Arctic and a High Arctic long-term research site. Ambio, 46, 160-173. https://doi.org/10.1007/s13280-016-0870-x

Hollesen, J., Buchwal, A., Rachlewicz, G., Hansen, B. U., Hansen, M. O., Stecher, O., \& Elberling, B. (2015). Winter warming as an important co-driver for Betula nana growth in western Greenland during the past century. Global Change Biology, 21(6), 2410-2423. https://doi.org/10.1111/gcb.12913

Hurrell, J. W. (1995). Decadal trends in the North Atlantic oscillation: Regional temperatures and precipitation. Science, 269(5224), 676-679. https://doi.org/10.1126/science.269.5224.676

Hurrell, J.W., Kushnir, Y., Ottersen, G., \& Visbeck, M. (2003). An overview of the north atlantic oscillation. Geophysical Monograph Series, 134, 1-35. https://doi.org/10.1029/134GM01

IPCC. (2019). IPCC, 2019: Climate Change and Land: an IPCC special report on climate change, desertification, land degradation, sustainable land management, food security, and greenhouse gas fluxes in terrestrial ecosystems.

Jones, P. D., Jonsson, T., \& Wheeler, D. (1997). Extension to the North Atlantic Oscillation using early instrumental pressure observations from gibraltar and south-west Iceland. International Journal of Climatology, 17(13), 1433-1450. https://doi.org/10.1002/(sici)1097-0088(19971115)17:13<1433::aidjoc203>3.3.co;2-g 
Koenigk, T., Caian, M., Nikulin, G., \& Schimanke, S. (2016). Regional Arctic sea ice variations as predictor for winter climate conditions. Climate Dynamics, 46(1-2), 317-337. https://doi.org/10.1007/s00382015-2586-1

Kruse, S., Wieczorek, M., Jeltsch, F., \& Herzschuh, U. (2016). Treeline dynamics in Siberia under changing climates as inferred from an individual-based model for Larix. Ecological Modelling, 338, 101-121. https://doi.org/10.1016/j.ecolmodel.2016.08.003

Kürschner, W. M. (1997). The anatomical diversity of recent and fossil leaves of the durmast oak (Quercus petraea Lieblein/ Quercus pseudocastanea Goeppert): implications for their use as biosensors of paleoatmospheric CO2 levels. Review of Palaeobotany and Palynology, 96(96), 1-30.

Li, J., Fan, K., \& Xu, Z. (2016). Links between the late wintertime North Atlantic Oscillation and springtime vegetation growth over Eurasia. Climate Dynamics, 46(3-4), 987-1000. https://doi. org/10.1007/s00382-015-2627-9

Marcos, R., Torralba, V., Cortesi, N., Soret, A., \& Doblas-reyes, F. J. (2016). Characterization of near surface wind speed and temperature statistical distributions (Issue January). https://earth.bsc.es/ wiki/lib/exe/fetch.php?media=library:external:bsc-ess-2016-006-rmarcos_wind_and_temperature_ distributions.pdf

Ottersen, G., Planque, B., Belgrano, A., Post, E., Reid, P. C., \& Stenseth, N. C. (2001). Ecological effects of the North Atlantic Oscillation. Oecologia, 128(1), 1-14. https://doi.org/10.1007/s004420100655

Park, H. S., Kim, S. J., Stewart, A. L., Son, S. W., \& Seo, K. H. (2019). Mid-Holocene Northern Hemisphere warming driven by Arctic amplification. Science Advances, 5(12). https://doi.org/10.1126/sciadv. aax8203

Polyakov, I. V., Bekryaev, R. V., Alekseev, G. V., Bhatt, U. S., Colony, R. L., Johnson, M. A., Maskshtas, A. P., \&Walsh, D. (2003). Variability and trends of air temperature and pressure in the maritime Arctic, 18752000. Journal of Climate, 16(12), 2067-2077. https://doi.org/10.1175/1520-0442(2003)016<2067:VAT OAT $>2.0 . C O ; 2$

R Core Team. (2020). R: A Language and Environment for Statistical Computing. R Foundation for Statistical Computing. https://www.r-project.org/

Rayback, S. A., \& Henry, G. H. R. (2006). Reconstruction of summer temperature for a Canadian high arctic site from retrospective analysis of the dwarf shrub, Cassiope tetragona. Arctic, Antarctic, and Alpine Research, 38(2), 228-238. https://doi.org/10.1657/1523-0430(2006)38[228:ROSTFA]2.0.CO;2

Rohde, R., A. Muller, R., Jacobsen, R., Muller, E., \& Wickham, C. (2013). A New Estimate of the Average Earth Surface Land Temperature Spanning 1753 to 2011. Geoinformatics \& Geostatistics: An Overview, 01(01), 1-7. https://doi.org/10.4172/2327-4581.1000101

Rohde, R., Muller, R., Jacobsen, R., Perlmutter, S., \& Mosher, S. (2013). Berkeley Earth Temperature Averaging Process. Geoinformatics \& Geostatistics: An Overview, 01(02). https://doi.org/10.4172/23274581.1000103

Sakashita, W., Yokoyama, Y., Miyahara, H., Aze, T., Obrochta, S. P., Ohyama, M., \& Yonenobu, H. (2018). Assessment of Northeastern Japan Tree-Ring Oxygen Isotopes for Reconstructing Early Summer Hydroclimate and Spring Arctic Oscillation. Geochemistry, Geophysics, Geosystems, 19(9), 35203528. https://doi.org/10.1029/2018GC007634 
Schmutz, C., Luterbacher, J., Gyalistras, D., Xoplaki, E., \& Wanner, H. (2000). Can we trust proxybased NAO index reconstructions? Geophysical Research Letters, 27(8), 1135-1138. https://doi. org/10.1029/1999GL011045

Steinthorsdottir, M., Wagner-cremer, F., \& Steinthorsdottir, M. (2019). Hot summers ahead? Multidecadal spring season warming precedes sudden summer temperature rise in pre-anthropogenic climate change summer temperature rise in pre-anthropogenic climate change. GFF, 00(00), 1-6. https://doi.org/10.1080/11035897.2019.1655791

Team, Q. D. (2021). QGIS Geographic Information System. QGIS Association. https://www.qgis.org

Trouet, V., \& Van Oldenborgh, G. J. (2013). KNMI Climate Explorer: A Web-Based Research Tool for High-Resolution Paleoclimatology. Tree-Ring Research, 69(1), 3-13. https://doi.org/10.3959/15361098-69.1.3

Uvo, C. B. (2003). Analysis and regionalization of northern European winter precipitation based on its relationship with the North Atlantic oscillation. International Journal of Climatology, 23(10), 11851194. https://doi.org/10.1002/joc.930

van Loon, H., \& Rogers, J. C. (1978). The Seesaw in Winter Temperatures between Greenland and Northern Europe. Part I: General Description. In Monthly Weather Review (Vol. 106, Issue 3, pp. 296310). https://doi.org/10.1175/1520-0493(1978)106<0296:TSIWTB>2.0.CO;2

Vinther, B. M., Johnsen, S. J., Andersen, K. K., Clausen, H. B., \& Hansen, A. W. (2003). NAO signal recorded in the stable isotopes of Greenland ice cores. Geophysical Research Letters, 30(7), 1-4. https://doi. org/10.1029/2002GL016193

Visbeck, M. H., Hurrell, J. W., Polvani, L., \& Cullen, H. M. (2001). The North Atlantic oscillation: Past, present, and future. Proceedings of the National Academy of Sciences of the United States of America, 98(23), 12876-12877. https://doi.org/10.1073/pnas.231391598

Wagner-Cremer, F., Finsinger, W., \& Moberg, A. (2010). Tracing growing degree-day changes in the cuticle morphology of Betula nana leaves: A new micro-phenological palaeo-proxy. Journal of Quaternary Science, 25(6), 1008-1017. https://doi.org/10.1002/jqs.1388

Walker, D. A., Raynolds, M. K., Daniëls, F. J., Einarsson, E., Elvebakk, A., \& Gould, W. A. (2005). The Circumpolar Arctic vegetation map. Journal of Vegetation Science, 16(3), 267-282. https://pubag.nal. usda.gov/download/41099/PDF

Wang, J., \& Ikeda, M. (2000). Arctic oscillation and Arctic Sea-Ice oscillation. Geophysical Research Letters, 27(9), 1287-1290. https://doi.org/10.1029/1999GL002389

Weijers, S., Beckers, N., \& Löffler, J. (2018). Recent spring warming limits near-treeline deciduous and evergreen alpine dwarf shrub growth. Ecosphere, 9(6). https://doi.org/10.1002/ecs2.2328

Weijers, S., Broekman, R., \& Rozema, J. (2010). Dendrochronology in the High Arctic: July air temperatures reconstructed from annual shoot length growth of the circumarctic dwarf shrub Cassiope tetragona. Quaternary Science Reviews, 29(27-28), 3831-3842. https://doi.org/10.1016/j. quascirev.2010.09.003

Weijers, S., Buchwal, A., Blok, D., Löffler, J., \& Elberling, B. (2017). High Arctic summer warming tracked by increased Cassiope tetragona growth in the world's northernmost polar desert. Global Change 
Biology, 23(11), 5006-5020. https://doi.org/10.1111/gcb.13747

Weijers, S., Wagner-Cremer, F., Sass-Klaassen, U., Broekman, R., \& Rozema, J. (2013). Reconstructing High Arctic growing season intensity from shoot length growth of a dwarf shrub. The Holocene, 23(5), 721-731. https://doi.org/10.1177/0959683612470178

Welker, J. M., Rayback, S., \& Henry, G. H. R. (2005). Arctic and North Atlantic Oscillation phase changes are recorded in the isotopes $(\delta 180$ and $\delta 13 C)$ of Cassiope tetragona plants. Global Change Biology, 11(7), 997-1002. https://doi.org/10.1111/j.1365-2486.2005.00961.x

Wipf, S., Stoeckli, V., \& Bebi, P. (2009). Winter climate change in alpine tundra: Plant responses to changes in snow depth and snowmelt timing. Climatic Change, 94(1-2), 105-121. https://doi. org/10.1007/s10584-009-9546-x

Xu, L., Myneni, R. B., Chapin III, F. S., Callaghan, T. V., Pinzon, J. E., Tucker, C. J., Zhu, Z., Bi, J., Ciais, P., Tømmervik, H., Euskirchen, E. S., Forbes, B. C., Piao, S. L., Anderson, B. T., Ganguly, S., Nemani, R. R., Goetz, S. J., Beck, P. S. a., Bunn, a. G., ... Stroeve, J. C. (2013). Temperature and vegetation seasonality diminishment over northern lands (SUPPLEMENTARY INFORMATION). Nature Climate Change, 3(3), 581-586. https://doi.org/10.1038/nclimate1836

Young, G. H. F., McCarroll, D., Loader, N. J., Gagen, M. H., Kirchhefer, A. J., \& Demmler, J. C. (2012). Changes in atmospheric circulation and the Arctic Oscillation preserved within a millennial length reconstruction of summer cloud cover from northern Fennoscandia. Climate Dynamics, 39(1-2), 495-507. https://doi.org/10.1007/s00382-011-1246-3

Young, N. E., Schweinsberg, A. D., Briner, J. P., \& Schaefer, J. M. (2015). Glacier maxima in Baffin Bay during the Medieval Warm Period coeval with Norse settlement. Science Advances, 1(11). https://doi. org/10.1126/sciadv.1500806 


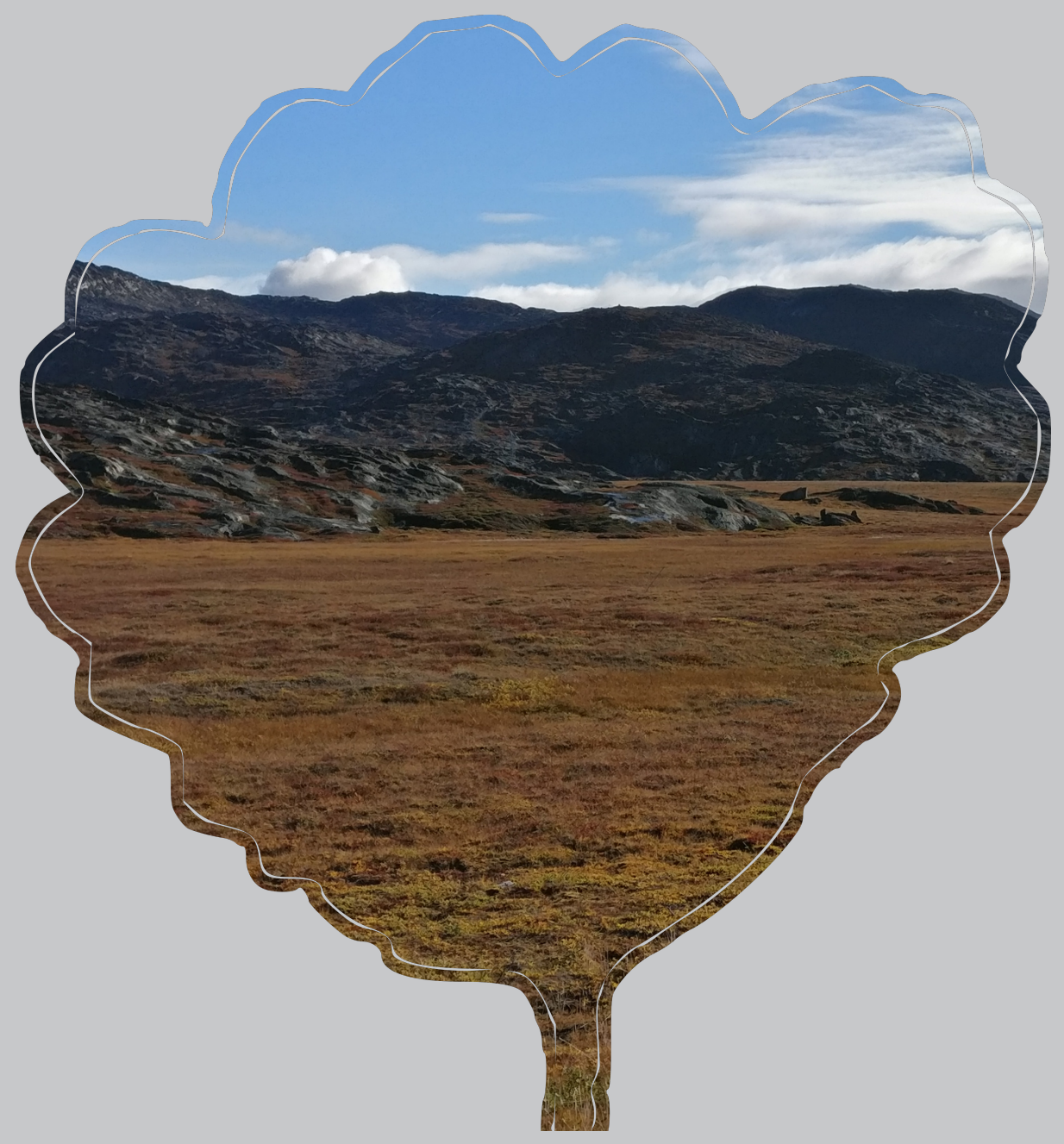




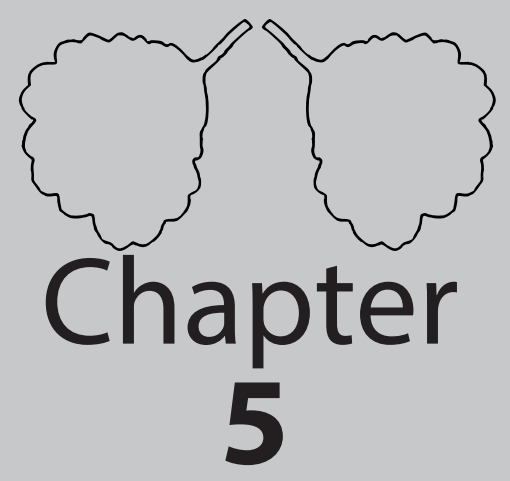




\title{
Limits of using Betula nana epidermal cell undulation for reconstructing extremely low thermal conditions
}

\author{
Fabian E.Z. Ercan ${ }^{1} \mid$ Hugo J. de Boer $\left.{ }^{2}\right\rfloor$ Juha Mikola ${ }^{3,4} \mid$ Daan Blok $^{5} \mid$ Tarja Silfver $^{3}$ \\ | Elina Vainio6 ${ }^{6}$ Friederike Wagner-Cremer \\ ${ }^{1}$ Palaeoecology, Department of Physical Geography, Utrecht University, The Netherlands \\ ${ }^{2}$ Copernicus Institute of Sustainable Development, Department of Environmental Sciences, Utrecht \\ University, The Netherlands \\ ${ }^{3}$ Faculty of Biological and Environmental Sciences, Ecosystems and Environment Research \\ Programme, University of Helsinki, Lahti, Finland \\ 4 Natural Resources Institute Finland (Luke), Helsinki, Finland \\ ${ }^{5}$ Dutch Research Council, (NWO), Den Haag, The Netherlands. \\ ${ }^{6}$ Kevo Subarctic Research Institute, Biodiversity Unit, Turku, Finland
}

As in review at The Holocene, 2021. 


\subsection{Abstract}

Biological proxies provide relevant information on environmental growth conditions in past climates, but require sensitivity tests to ensure the accuracy of reconstructions. Betula nana epidermal cell undulation, quantified as the Undulation Index (UI), is commonly applied to reconstruct past growing season thermal conditions from fossil leaf remains. These UI-based inference models for seasonal temperature variation, expressed as growing degree days (GDDs), are based on spatio-temporal leaf growth monitoring and cover a considerable range of modern GDDs. As there is a current lack of clean knowledge on the ranges of application of the proxy and specifically the responsiveness near the lower temperature range, we examined the lower limits of $\mathrm{UI}_{\text {I }}$ response to $\mathrm{GDD}_{5}$ using data collected from $B$. nana shrubs growing near their lower temperature range. We estimated a response model using natural long-term $\mathrm{UI}_{-} \mathrm{GDD}_{5}$ data collected in Disko Island (West Greenland, 69 ${ }^{\circ} 16 \mathrm{~N} 53^{\circ} 27 \mathrm{~W}$ ) and Utsjoki Kevo (Northern Finland, $\left.69^{\circ} 45 \mathrm{~N}, 27^{\circ} 00 \mathrm{E}\right)$. To evaluate the applicability of short-term temperaturecontrolled field experiments to produce palaeoecological proxies, we then compared the model to the UI data collected from experiments in the same field sites. The long-term response model showed that meaningful reconstructions are possible for $\mathrm{GDD}_{5}$ values over $\sim 300$, while the UI response below $\sim 300 \mathrm{GDD}$ 5 appears too weak to provide a reliable signal. Additional proxies, such as stomata size variation appear valuable for such, very low thermal conditions. The short-term experimental data was not entirely consistent with the long-term data, suggesting that cautiousness is needed when using experimentally produced proxies. On the other hand, the experimental data confirmed that B. nana UI can also applied for reconstructing drought stress. 


\subsection{Introduction}

Leaf cuticle-based proxies of fossil leaf remains are commonly utilized to reconstruct a variety of environmental parameters to provide information on growth conditions in past climates. To complement the well-tested stomatal frequency proxies, applied in palaeoatmospheric $\mathrm{CO}_{2}$ reconstructions (Birks, 2020), studies have recently focused on using lateral epidermal cell growth patterns to reconstruct past canopy conditions (Cheesman et al., 2020; Dunn et al., 2015) and growing season thermal properties (Ercan et al., 2020; Finsinger et al., 2013; Steinthorsdottir and Wagner-Cremer, 2019; Wagner-Cremer et al., 2010b). Lateral epidermal cell growth is expressed as the Undulation Index (UI), which quantifies the degree of cell wall sinuosity over the cell size. It was originally introduced to qualitatively assess light dependent development of sun and shade morphotypes in angiosperm leaves (Kürschner, 1997), and Ul sensitivity tests for light conditions are available via withincanopy leaf monitoring and leaf area index (LAl) comparisons (Cheesman et al., 2020; Dunn et al., 2015). The responsiveness of UI to growing season temperatures has been tested utilizing long-term monitoring data and spatial data covering climatic gradients (Ercan et al., 2020; Wagner-Cremer et al., 2010). Application of $\mathrm{UI}$ as a proxy for temperature is restricted to shade intolerant open canopy shrubs and trees, in which the confounding variation in light morphotype development of epidermal cells is minimal. Research on developing $\mathrm{UI}$ proxy has consequently focused on Arctic and/or pioneer species, and especially the birches Betula nana and $B$. pubescens have revealed good results.

In terms of Ul responsiveness to growing season thermal conditions, expressed as growing degree days (GDD), the epidermal cell undulation of B. nana is covered most thoroughly (Ercan et al., 2021; Wagner-Cremer, et al., 2010). The obtained GDD inference model for fossil B. nana UI data has successfully been applied in late Quaternary climate reconstructions (Finsinger et al., 2013; Steinthorsdottir and Wagner-Cremer, 2019; Wagner-Cremer and Lotter, 2011). With the increasing application of the UI, however, questions have risen considering the response limits of the proxy, and thus the range of growing season temperatures that can be securely quantified. Response limits are important to establish as they help to define the valid application range of proxies and thereby increase the reliability of environmental and climatic reconstructions. In the case of $B$. nana, this is especially urgent for the extremely low temperatures the species is exposed to in its current Arctic distribution and was exposed to during early succession phases of Quaternary climate swings. 
To examine the lower limit of $B$. nana $\mathrm{UI}$ response to GDD, we will test the GDD response of $\mathrm{UI}$ in $B$. nana leaf samples collected under known temperatures in Greenland and Northern Finland, the main present-day distribution range of this species. We will then compare the obtained model to UI data collected from temperature-controlled field experiments from the same sites to evaluate the suitability of experimental data as palaeoecological proxies. Based on these data, we will lastly discuss the limits of using $B$. nana $\mathrm{UI}$ to reconstruct very low growing season temperatures.

\subsection{Materials and Methods}

\subsubsection{Study area and B. nana leaf samples}

To cover the Arctic distribution range of B. nana, leaf material was collected from sites in contrasting regions: Disko Island, Greenland and Utsjoki Kevo, Finland (Figure 5.1). The results are compiled from earlier studies that include (i) annual leaf monitoring for years 1996-2017 (excluding 1998 and 2016) in the long-term annual leaf monitoring in the arboretum and natural environment at the Kevo Subarctic Research Institute $\left(69^{\circ} 45.4^{\prime \prime} \mathrm{N}, 27^{\circ} 00.5^{\prime \prime} \mathrm{E}\right)$ (Steinthorsdottir and WagnerCremer, 2019) ( $n=146$ ) and (ii) herbarium leaf samples for years 1898-1996 in the Disko area $(n=45)$. Experimental leaf samples are from (iii) an open-air activewarming experiment, with ten ambient and ten $+3{ }^{\circ} \mathrm{C}$ treatment plots established at the Kevo Subarctic Research Institute, covering years 2017 and 2018 (Ercan et al., 2021; Silfver et al., 2020) ( $n=84)$, and from (iv) a CENPERM Open Top Chamber (OTC) experiment carried out at Disko Island (69.16N 53⒉W), covering years 2013 and 2017 (Ercan et al., 2021) ( $n=36)$. The OTC set-up realized a mean warming of $2.5^{\circ} \mathrm{C}$ compared to ambient air temperatures in spring and summer (Blok et al., 2016). 


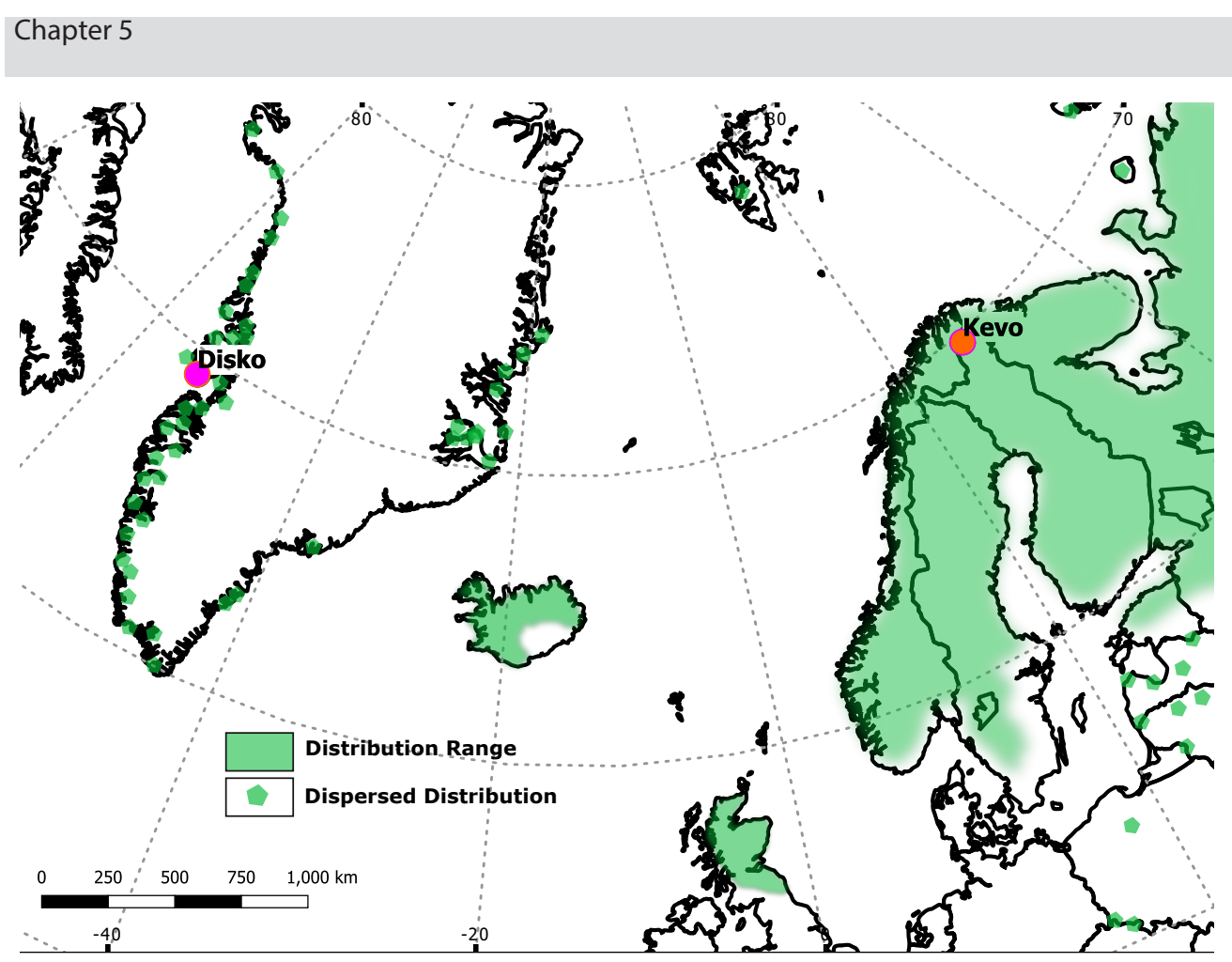

Figure 5.1: Present day B. nana distribution in the north-east Atlantic region (excluding Alpine populations and circumpolar sub-species). Green shading indicates full range, green dots indicate dispersed range (modified from Drzymulska, 2014; Hultén \& Magnus, 1986). Compiled using QGIS (QGIS Development Team, 2021) and a shape downloaded from http://tapiquen-sig.jimdofree.com. Carlos Efraín Porto Tapiquén. Geografía, SIG y Cartografía Digital. Valencia, Spain, 2020.

\subsubsection{Undulation Index (UI)}

The $\mathrm{UI}$ is a ratio of the epidermal cell circumference and the circumference of a circle with the same area as the cell and thus quantifies the sinuosity or undulation of the epidermis cell wall (Kürschner, 1997). Ul is calculated using equation 5.1:

$$
U I[\text { dimensionless }]=\frac{C_{C}}{2 \pi \sqrt{A_{C} / \pi}}
$$

\section{[Equation 5.1]}

where $A C$ is the mean epidermal cell area $\left(\mu m^{2}\right)$, and $C C$ is the epidermal cell circumference $(\mu \mathrm{m})$. The protocol for cuticle analysis involves AC and CC measurement for approximately 30 random alveole pavement cells per leaf fragment, performed on one or more digital microscopic images (Wagner-Cremer 

reconstructing extremely low thermal conditions

et al., 2010). For full analysis of modern material, a minimum of five leaves for each studied year or treatment is measured; fossil leaf fragment number depends on the availability of samples (Wagner-Cremer et al., 2010; Ercan et al., 2020). To illustrate the variation of $\mathrm{UI}$ in B. nana leaves, examples are shown in figure $\mathbf{5 . 2}$.

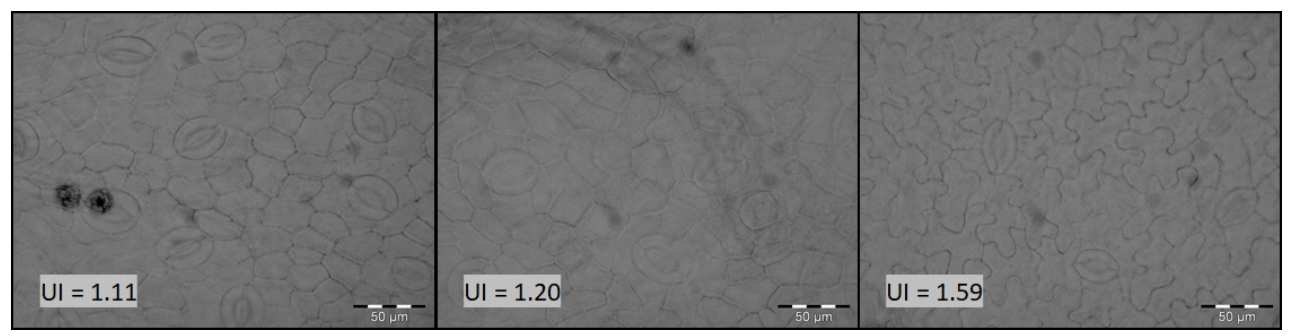

Figure 5.2: From left to right; examples of low (1.11), medium (1.20), and high (1.59) B. nana epidermal cell undulations expressed as UI. Note the size variability of the stomata in the left, low UI image, where small size indicates that the leaf is not fully matured.

The additional geometric shapes considered in this study to provide theoretical minimum UI values are tessellating shapes, i.e., they are self-repeating and can fully cover a given surface; the triangle, square and hexagon. The circle is nontessellating, as it cannot fully cover a given surface by self-repetition.

\subsubsection{Growing Degree Days (GDD)}

$\mathrm{GDD}_{\mathrm{x}}$ (Equation 5.2) expresses the growing potential for vegetation in a given year and is the cumulative sum of degrees Celsius above a threshold temperature X (McMaster and Wilhelm, 1997; Weijers et al., 2013):

$$
G D D_{X}=\sum_{i=1}^{\# \text { days }}\left(T_{i}-X\right), \quad T_{i} \geq X
$$

[Equation 5.2]

where $\mathrm{Ti}$ is the daily mean temperature for day $\mathrm{i}$ at the study site and $\mathrm{X}$ is the selected threshold temperature. We used $5^{\circ} \mathrm{C}$ as the threshold temperature (GDD5) as it is commonly used in the latitudinal range covered in our study (Carter, 1998). $\mathrm{GDD}_{5}$ was calculated from January 1 st to the date of leaf collection (Trouet and Van Oldenborgh, 2013) using the meteorological data available for both study sites. The effect of experimental warming on GDD5 was calculated using the temperatures measured at individual treatment plots (Blok et al., 2016). 


\subsubsection{UI-GDD relation}

The UI-GDD5 relation was parameterized by fitting a nonlinear model to the herbarium and long-term monitoring data from Disko Island and Kevo, respectively, in R statistical environment with the ggplot2 package (Bates and Chambers, 1992; Bates and Watts, 1988; R Core Team, 2020; Wickham, 2016). The obtained function was then compared with the short-term experimental data from the same sites to test if the experimentally produced UI-GDD5 relation follows the trend found in long-term monitoring in natural conditions.

\subsection{Results}

In the Disko herbarium data, the growing degree days varied from 8.6 to 332 GDD5, while the range in the Kevo monitoring data was from 303 to 1041 GDD5, as measured by the day of leaf collection (Figure 5.3). When the data were combined, the response of UI to GDD5 (Figure 5.3) was best described $\left(R^{2}=0.75, p<0.001\right.$ ) by equation 5.3:

$$
U I=1.166+1.641 \times 10^{-7} \times G D D_{5}^{1.966}
$$

[Equation 5.3]

Comparing this equation to the data from controlled growth experiments at the same sites (Figure 4) showed that the equation could explain $57 \%$ of the UI variation in these data $\left(R^{2}=0.57, p<0.001\right)$. However, the Disko data and the Kevo 2018 data mostly remained below the UI temperature response expressed by the equation (Figure 5.4). 


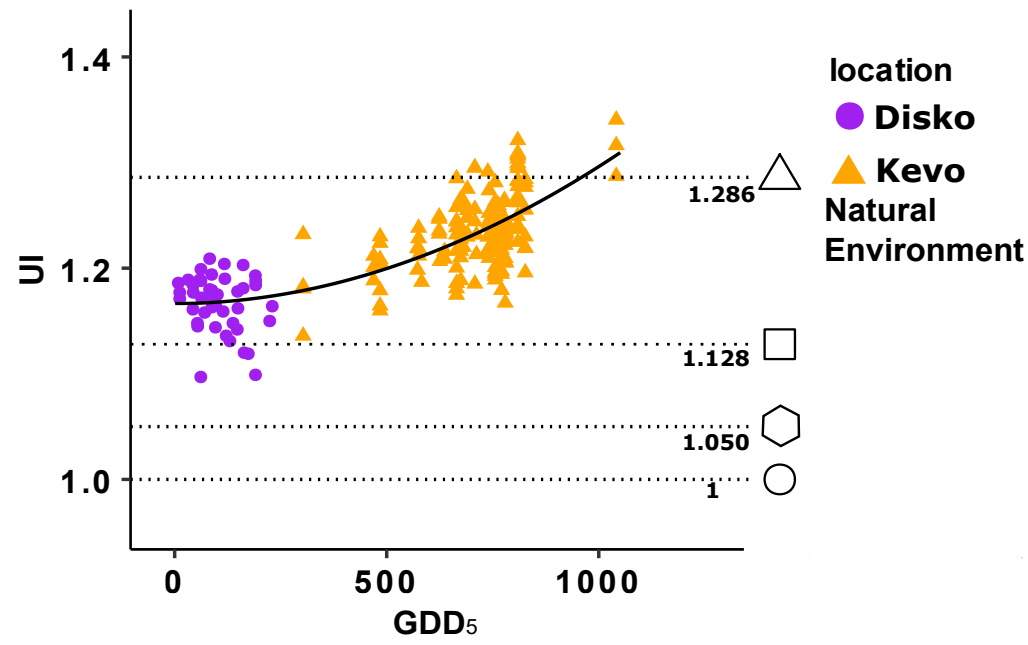

Figure 5.3: Association of $B$. nana $\mathrm{UI}$ and $\mathrm{GDD}_{5}$ in natural environments in the long-term Disko and Kevo data. Horizontal lines represent the four UI geometric shapes. Fitted function (solid line) describes the course of UI-GDD5 relation trajectory $\left(\mathrm{UI}=1.166+1.641 \mathrm{e}-07 \times \mathrm{GDD}_{5}{ }^{1.966}, R^{2}=0.75\right.$, $p<0.001)$.

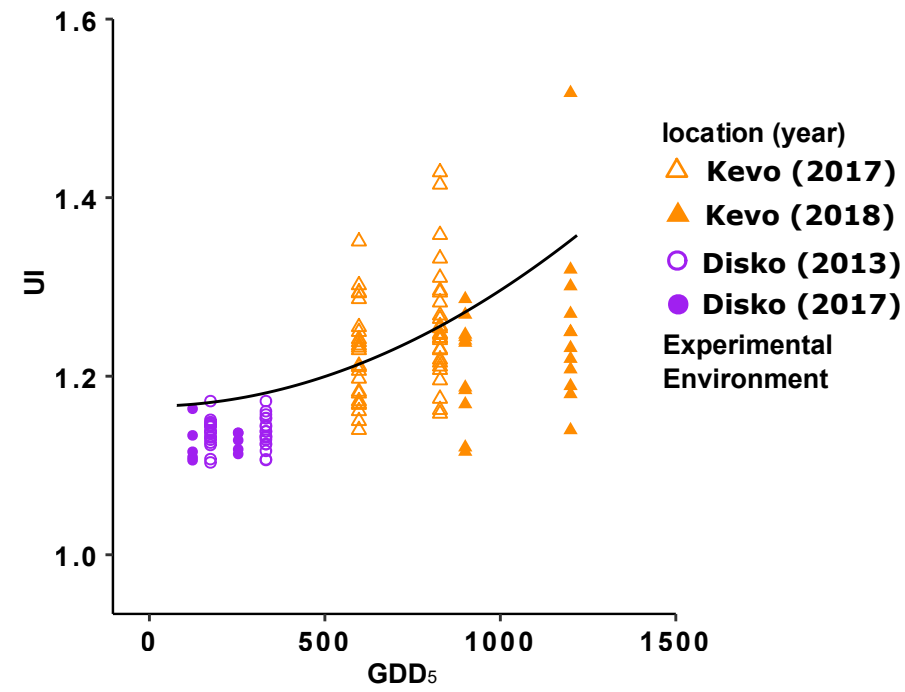

Figure 5.4: Association of B. nana $\mathrm{UI}$ and $\mathrm{GDD}_{5}$ in Disko and Kevo experimental data. The function (solid line) describes the UI-GDD5 association found in the long-term natural environment data (Fig. 5.3). 


\subsection{Discussion}

\subsubsection{Epidermal cell geometry during leaf maturation and under thermal constraints}

After the initial cell division, the morphogenesis of epidermal cells starts from small straight-walled hexagonal shapes that increase size during leaf expansion. The following undulation of cell walls leads to jigsaw puzzle-piece shapes in later maturation stages (Sapala et al., 2018). Undulation of large epidermal cells reduces mechanical stress and supports the incorporation of stomata and stomatal complexes, especially in the adaxial epidermal layer, thus providing integrity in the epidermal layer (Jacques et al., 2014; Sapala et al., 2018; Vőfély et al., 2019). The epidermal cell morphogenesis continues through the entire leaf growth period to full maturation and is easily recognizable on modern and fossil leaf cuticles (Wagner et al., 2007). The UI is a tool to quantify the degree of this epidermal cell undulation, and thus provides a way to quantify the stage the leaf has reached during the available growth season.

Based on the definition of UI, the theoretical minimum of UI is 1 (Kürschner, 1997). However, as UI in cuticle analysis is used to illustrate the shape of pavement cells in the epidermal layer, it can never reach 1 as perfect circles cannot fill a surface. The geometric shapes which can fill a surface through repetitions are triangles $(U I=1.286)$, squares $(U I=1.128)$ and hexagons $(U I=1.05)$. The full hexagon model has previously been used to describe epidermal cell coverage on plant leaves (Korn, 1994) and it also fits our data, where near hexagonal forms are the main shape in leaves grown under very low GDD5. The majority of samples from the Greenlandic sites belongs to this group. The epidermal cell shapes become more complex with increasing GDD5 as later epidermal cell growth stages can be achieved under warmer conditions; such shapes prevail in samples collected in Kevo. Our results show that not even the artificial warming in the Greenlandic experimental sites could release temperature stress to a degree that would have allowed leaves to mature and cell wall undulation to take place.

\subsubsection{Limits of UI as a GDD5 proxy}

Our results show that $B$. nana leaf cell $\mathrm{UI}$ is sensitive to heat sum accumulation in a wide range from $\sim 10$ to $\sim 1200$ GDD5. As our study includes a mix of experimental, monitoring and herbarium leaf material from two remote locations within the 
current distribution area of the species, the data likely represents much of the overall natural variation of $B$. nana UI.

The most pronounced response of UI to growing season heat sum accumulation seems to occur between 500 and 1000 GDD 5 . Below 500 GDD 5 and towards the most extreme conditions of $<100 \mathrm{GDD}_{5}$, the response is modest and hardly detectable below 200 GDD5. Such a non-linear response curve to temperature has also been demonstrated for alternative proxies such as stomatal frequency and gsmax response to $\mathrm{CO}_{2}$ concentration, where the responsiveness levels off and reaches the lower limit at various $\mathrm{CO}_{2}$ concentrations (de Boer et al., 2011; Kürschner et al., 1996; Lammertsma et al., 2011). Fitting the UI response model that we obtained from long-term monitoring and herbarium data to leaf material collected from experimental set-ups reveals that single year data from warming experiments may partly miss the temperature response observed in long-term monitoring and sample collection. This warrants caution when using experimental treatments to provide proxies for reconstructing past environmental conditions. While the Kevo 2017 data fits well with the long-term model, both years in Disko and year 2018 in Kevo suggest lower UI response to temperature than the long-term model. Year 2018 was extremely dry in Scandinavia, including northern Finland (Wilcke et al., 2020) and led to a significant plant drought stress in these areas (Silfver et al. 2020). Our results show that the drought resulted in lower UI than what could be predicted based on heat sum accumulation. The growth restrictive power of drought is a common phenomenon and has been shown with fossil leaf cuticles, too (Wagner-Cremer et al., 2010), but it had not been observed during the longterm monitoring in Kevo. The results show that $B$. nana leaf $U I$ is not solely sensitive to temperature but can also be used to reconstruct drought if other proxies for temperature are simultaneously available.

The wide temperature range and geographical distribution compiled in this study reveals that the UI-GDD5 relation is nonlinear, while earlier studies, using more regional data sets of $B$. nana and $B$. pubescens from Finland, have shown that the UI-GDD5 relation in the range of $300-1000 \mathrm{GDD}_{5}$ is best described by simple linear regression (Wagner-Cremer et al., 2010; Ercan et al, 2020). In our data set, the relation becomes less clear across the Greenlandic growing seasons with 8.6-230 GDD5. The lower response limit of $\mathrm{UI}_{\text {I }}$ to $\mathrm{GDD}_{5}$ apparently occurs within this range, but we cannot specify it with our data.

In the Greenlandic samples with very low UI values, the restricted leaf maturation 
was linked to frequent immature stomata or large range of stomatal sizes in individual samples (Figure 5.2; Wagner et al., 2007). Leaf samples from Finland, on the contrary all represented mature stages with fully developed stomata, and no samples with high stomatal size variation were observed (Figure 5.2). Observations of ontogenetic development in the royal fern Osmunda regalis have revealed that final stomatal size is achieved once approximately $30 \%$ of final leaflet size is reached. Although stomatal ripening may vary among species, large variation in stomatal size on an individual leaf sample is considered as a reliable indication of an early developmental stage (Wagner et al., 2007). Including additional observations such as stomatal development may thus help to evaluate leaf maturation stage in fossil cuticle data that represent the lowest range of UI responses.

\subsection{Conclusions}

Ul is of particular interest as a GDD5 proxy in the palaeoecological community, where it is used to reconstruct thermal conditions during growing seasons in retrospect. For B. nana, the lower limit of $\mathrm{UI}$ response is especially important as this species is commonly used for proxy-based reconstructions in present-day cold regions, or in cold climates of the past (Ercan et al., 2020; Steinthorsdottir and Wagner-Cremer, 2019; Wagner-Cremer et al., 2010). The results of the present study, combined with earlier observations, suggest that $\mathrm{UI}$ is applicable as GDD5 proxy over a wide range of temperatures and the main geographical distribution of $B$. nana under present day conditions. Using additional proxies such as stomata size and stomata size variation may though be needed, or at least be helpful, when evaluating leaf maturation stage for samples that represent the low limit of UI response. It also appears that Betula nana $\mathrm{UI}$ is applicable in restructuring drought stress, while cautious is needed when using proxies derived from short-term experimental data to reconstruct past conditions.

\subsection{Acknowledgements}

We greatly acknowledge the support of the University of Copenhagen for providing access to the herbarium samples from Disko Island, and the support by the Kevo Subarctic Research Station. 


\subsection{Literature}

Bates DM and Chambers JM (1992) Nonlinear models. In: Chambers JM and Hastie TJ (eds) Statistical Models. Wadsworth \& Brooks/Cole.

Bates DM and Watts DG (1988) Nonlinear Regression Analysis and Its Applications. Wiley.

Birks HJB (2020) Reflections on the Use of Ecological Attributes and Traits in Quaternary Botany. 8(May): 1-13: doi:10.3389/fevo.2020.00166.

Blok D, Elberling B and Michelsen A (2016) Initial Stages of Tundra Shrub Litter Decomposition May Be Accelerated by Deeper Winter Snow But Slowed Down by Spring Warming. Ecosystems. Springer US 19(1): 155-169: doi:10.1007/s10021-015-9924-3.

Carter TR (1998) Changes in the thermal growing season in Nordic countries during the past century and prospects for the future. Agricultural and Food Science 7(2): 161-179: doi:10.23986/afsci.72857.

Cheesman AW, Duff H, Hill K, Cernusak LA and McInerney FA (2020) Isotopic and morphologic proxies for reconstructing light environment and leaf function of fossil leaves: a modern calibration in the Daintree Rainforest, Australia. American Journal of Botany 107(8): 1165-1176: doi:10.1002/ajb2.1523.

de Boer HJ, Lammertsma El, Wagner-Cremer F, Dilcher DL, Wassen MJ and Dekker SC (2011) Climate forcing due to optimization of maximal leaf conductance in subtropical vegetation under rising $\mathrm{CO} 2$. Proceedings of the National Academy of Sciences 108(10): 4041-4046: doi:10.1073/pnas.1100555108.

Drzymulska D (2014) Postglacial occurrence and decline of Betula nana L. (dwarf birch) in northeastern Poland. Estonian Journal of Earth Sciences 63(2): 76-87: doi:10.3176/earth.2014.07.

Dunn RE, Strömberg CAE, Madden RH, Kohn MJ and Carlini AA (2015) Linked canopy, climate, and faunal change in the Cenozoic of Patagonia. Science 347(6219): 258-261: doi:10.1126/ science. 1260947.

Ercan FEZ, De Boer HJ and Wagner-Cremer F (2020) A growing degree day inference model based on mountain birch leaf cuticle analysis over a latitudinal gradient in Fennoscandia. Holocene 30(2): 344-349: doi:10.1177/0959683619865605.

Ercan FEZ, Mikola J, Silfver T, Myller K, Vainio E, Słowińska S, Słowiński M, Lamentowicz M, Blok D \& Wagner-Cremer F (2021) Effects of experimental warming on Betula nana epidermal cell growth tested over its maximum climatological growth range. PLoS ONE 16(5): 1-12: doi:10.1371/journal. pone.0251625.

Finsinger W, Schoning K, Hicks S, Lücke A, Goslar T, Wagner-Cremer F, et al. (2013) Climate change during the past 1000 years: A high-temporal-resolution multiproxy record from a mire in northern Finland. Journal of Quaternary Science 28(2): 152-164: doi:10.1002/jqs.2598.

Hultén E and Magnus F (1986) Atlas of North European vascular plants north of the Tropic of Cancer. Königstein: Koeltz Scientific Books.

Jacques E, Verbelen JP and Vissenberg K (2014) Review on shape formation in epidermal pavement cells of the Arabidopsis leaf. Functional Plant Biology 41(9): 914-921: doi:10.1071/FP13338.

Korn RW (1994) Pattern formation in plant epidermis through inhibition of immediately adjacent cells

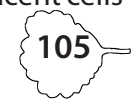


by pattern elements. Protoplasma 180(3-4): 145-152: doi:10.1007/BF01507850.

Kürschner WM (1997) The anatomical diversity of recent and fossil leaves of the durmast oak (Quercus petraea Lieblein/ Quercus pseudocastanea Goeppert): implications for their use as biosensors of paleoatmospheric CO2 levels. Review of Palaeobotany and Palynology 96(96): 1-30.

Kürschner WM, van der Burgh J, Visscher H and Dilcher DL (1996) Oak leaves as biosensors of late neogene and early pleistocene paleoatmospheric $\mathrm{CO} 2$ concentrations. Marine Micropaleontology 27(1-4): 299-312: doi:10.1016/0377-8398(95)00067-4.

Lammertsma El, de Boer HJ, Dekker SC, Dilcher DL, Lotter AF and Wagner-Cremer F (2011) Global $\mathrm{CO} 2$ rise leads to reduced maximum stomatal conductance in Florida vegetation. Proceedings of the National Academy of Sciences 108(10): 1-6: doi:10.1073/pnas.1100371108.

McMaster GS and Wilhelm WW (1997) Growing degree-days: one equation, two interpretations. Agricultural and Forest Meteorology 87(1): 291-300.

R Core Team (2020) R: A Language and Environment for Statistical Computing. Vienna, Austria: R Foundation for Statistical Computing. Available at: https://www.r-project.org/.

Sapala A, Runions A, Routier-Kierzkowska AL, Gupta M Das, Hong L, Hofhuis H, et al. (2018) Why plants make puzzle cells, and how their shape emerges. eLife 7: 1-32: doi:10.7554/eLife.32794.

Silfver T, Heiskanen L, Aurela M, Myller K, Karhu K, Meyer N, et al. (2020) Insect herbivory dampens Subarctic birch forest $C$ sink response to warming. Nature Communications. Springer US 11(1): 1-9. Available at: http://dx.doi.org/10.1038/s41467-020-16404-4: doi:10.1038/s41467-020-16404-4.

Steinthorsdottir M and Wagner-Cremer F (2019) Hot summers ahead? Multi-decadal spring season warming precedes sudden summer temperature rise in pre-anthropogenic climate change. Gff. Taylor \& Francis 141(3): 175-180. Available at: https://doi.org/10.1080/11035897.2019.1655791: do i:10.1080/11035897.2019.1655791.

Team QD (2021) QGIS Geographic Information System. QGIS Association. Available at: https://www. qgis.org.

Trouet V and Van Oldenborgh GJ (2013) KNMI Climate Explorer: A Web-Based Research Tool for HighResolution Paleoclimatology. Tree-Ring Research 69(1): 3-13. Available at: http://www.bioone.org/ doi/abs/10.3959/1536-1098-69.1.3: doi:10.3959/1536-1098-69.1.3.

Vőfély R V., Gallagher J, Pisano GD, Bartlett M and Braybrook SA (2019) Of puzzles and pavements: a quantitative exploration of leaf epidermal cell shape. New Phytologist 221(1): 540-552. Available at: https://www.biorxiv.org/content/early/2018/07/03/361717: doi:10.1111/nph.15461.

Wagner-Cremer F, Donders TH and Visscher H (2010a) Drought stress signals in modern and subfossil Quercus laurifolia (Fagaceae) leaves reflect winter precipitation in southern Florida tied to El NiñoSouthern Oscillation activity. American Journal of Botany 97(5): 753-759: doi:10.3732/ajb.0900196.

Wagner-Cremer F, Finsinger W and Moberg A (2010b) Tracing growing degree-day changes in the cuticle morphology of Betula nana leaves: A new micro-phenological palaeo-proxy. Journal of Quaternary Science 25(6): 1008-1017: doi:10.1002/jqs.1388.

Wagner-Cremer F and Lotter AF (2011) Spring-season changes during the Late Pleniglacial and

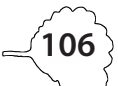


Bølling/Allerød interstadial. Quaternary Science Reviews 30(15-16): 1825-1828. Available at: http:// linkinghub.elsevier.com/retrieve/pii/S0277379111001399: doi:10.1016/j.quascirev.2011.05.003.

Wagner F, Visscher H, Kürschner WM and Dilcher DL (2007) Influence of Ontogeny and Atmospheric CO2 on Stomata Parameters of Osmunda regalis. CFS Courier Forschungsinstitut Senckenberg 258: 183-189.

Weijers S, Wagner-Cremer F, Sass-Klaassen U, Broekman R and Rozema J (2013) Reconstructing High Arctic growing season intensity from shoot length growth of a dwarf shrub. The Holocene 23(5): 721-731. Available at: http://journals.sagepub.com/doi/10.1177/0959683612470178: doi:10.1177/0959683612470178.

Wickham H (2016) ggplot2: Elegant Graphics for Data Analysis. New York: Springer-Verlag. Available at: http://ggplot2.org.

Wilcke RAI, Kjellström E, Lin C, Matei D, Moberg A and Tyrlis E (2020) The extremely warm summer of 2018 in Sweden - Set in a historical context. Earth System Dynamics 11(4): 1107-1121: doi:10.5194/ esd-11-1107-2020. 


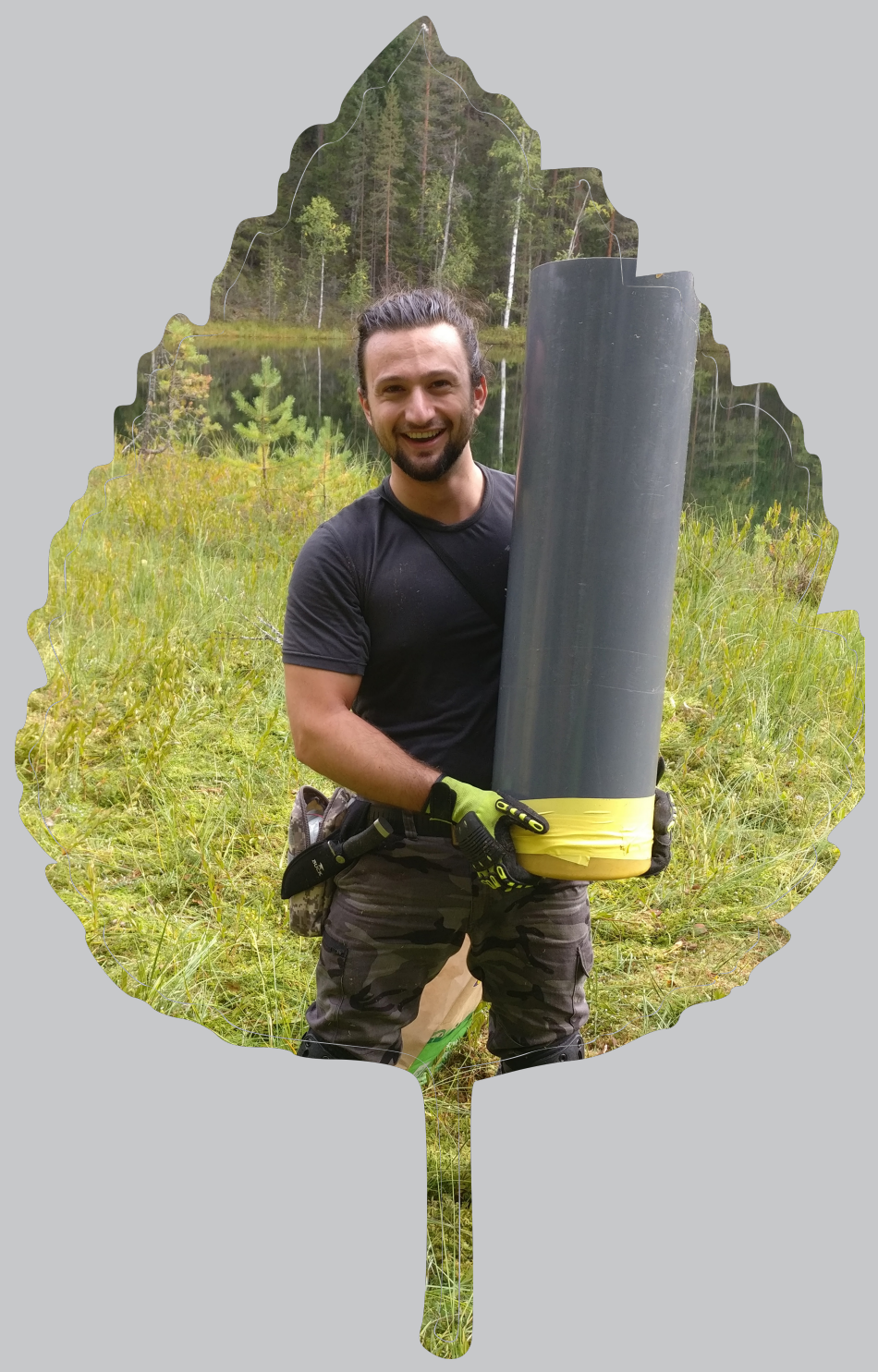




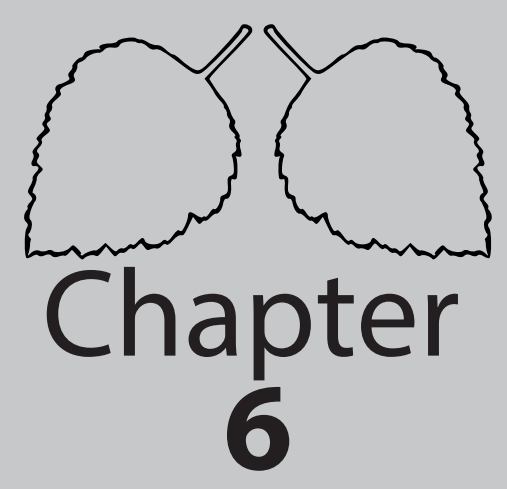




\title{
Spring temperature changes during the last 1300 years based on Betula pubescens leaves from Denmark
}

\author{
Fabian E.Z. Ercan' | Catrien M. Hoffman' | Wim Z. Hoek² | Friederike Wagner- \\ Cremer $^{1}$ \\ ${ }^{1}$ Palaeoecology, Department of Physical Geography, Utrecht University, The Netherlands \\ ${ }^{2}$ Global Change Geomorphology, Department of Physical Geography, Utrecht University, The \\ Netherlands
}

As to be submitted, 2022

\begin{abstract}
6.1 Abstract
Here we present a new climate reconstruction of seasonality changes for the last 1300 years in NE-Denmark. The results from the Lille Gribsø growing degree day $\mathrm{GDD}_{5}$ record, based on Betula pubescens leaves, compare with other records providing information on growing season temperatures (March - September) in and around central Scandinavia. The course of changes and transitions evident in the record shows good agreement with other reconstructions of regional spring dynamics and growing season. The record reveals reoccurring phases of colder conditions that supports the idea that climate cooling is triggered by a combination of decreased solar activity and pulses of volcanic forcing. In turn, the record shows remarkable synchronicity with larger scale historical events such as the Little Ice Age and Medieval Climate Anomaly in the region.
\end{abstract}




\subsection{Introduction}

The link between climate and societal development, welfare and behaviour in preindustrial times is intensively studied as it provides a context for evaluating the potential consequences of ongoing climate change (Degroot et al., 2021). Particularly well documented are temperature and precipitation anomalies during the past Millennium in different proxy records which provide information on the climatological background under which people in NW Europe lived (Degroot et al., 2021; Gouw-Bouman et al., 2019). Summer temperature reconstructions based on chironomids (Zawiska et al., 2017) and tree-ring analysis (Ljungqvist, 2010; Zhang et al., 2015), as well as reconstructions of hydrological changes (Büntgen et al., 2021) reveals a connection between cold and/or wet periods such as the Medieval Dark Ages Cold Period (DACP) or the Little Ice Age (LIA) and widespread poverty in many parts of NW Europe. In this region the societies overall benefit from the improving living conditions during climate amelioration such as the Medieval Climatic Anomaly (MCA) and the Modern Optimum (MO) (Huhtamaa and Helama, 2017; Ljungqvist, 2010; Luterbacher et al., 2016). Although the climate - society link is increasingly documented, records of changing spring season conditions are still largely missing. Spring season plays an important role in ecological and phenological processes, but are also crucial for agricultural crop productivity (Zhang et al., 2011). Prolonged phases of cold or wet spring weather have a negative impact on agricultural productivity which ultimately can lead to food shortages and famine (Ljungqvist et al., 2021b, 2021a). Not only prolonged phases of specific conditions like volcanic-solar downturns need to be considered(Ahmed et al., 2013), but also single-year events such as the extremely hot and dry spring of 2018 in NW Europe (Wilcke et al., 2020), and the multiple-year drought leading up to the Syrian conflict (Kelley et al., 2015). These extreme weather events are likely to increase in frequency under ongoing climate change, affecting crop yield, and will shape modern societies as well.

Quantification of past spring season thermal conditions is thus relevant to further reduce uncertainties in the reconstructions that arise from records that do cover the relevant season of the year for agriculture (Ljungqvist et al., 2021b) and to evaluate the occurrence of spring weather extremes against the background of modern climate change (Steinthorsdottir and Wagner-Cremer, 2019).

The thermal properties of the entire growing season including the most sensitive months March, April and May can be quantified by the birch-leaf based 
paleobotanical reconstruction technique providing growing degree day (GDD) intensity, accumulating throughout the growing season (Ercan et al., 2020; WagnerCremer et al., 2010), as used this study. A quantifiable imprint of spring onset date and GDD is measurable in the microscopic leaf morphology of Betula (Birch) leaves (Steinthorsdottir et al., 2019; Wagner-Cremer et al., 2010). The microphenological proxy captures the degree of epidermal cell maturation in birch leaves which is directly related to the temperature conditions and length of the growing season. The degree of cell-maturation is thereby quantified as the undulation index (UI), which is the ratio of cell circumference over cell area (Kürschner, 1997; Wagner-Cremer et al., 2010). The UI has been applied to deduce spring versus summer temperature over the natural climate variations during the last deglaciation (Steinthorsdottir and Wagner-Cremer, 2019). Applied to time-series spanning the past century deduced from herbarium samples and young peat deposits, the sensitivity of morphological adaptations in Betula nana (Dwarf Birch) even captures multiannual spring weather conditions relating to the North Atlantic Oscillation over Scandinavia (Ercan et al., 2021, Polar Research [Chapter 4]). Recent spatial analysis of Betula pubescens (Downy Birch) leaves sampled over a large latitudinal gradient with significant differences in the growth period and temperature confirmed the stimulation of cell expansion under increasing GDD also in this common tree birch species and its hybrids with B. nana (Ercan et al., 2020). B. pubescens leaves are a highly abundant components of macrofossils preserved in lake deposits, which makes them extremely suitable to produce continuous time-series data in a wide range of geographical settings.

In the present study, we focus on lake deposits obtained from a kettle hole in Northeast Sealand, Denmark covering the period from the 7th century CE to present. The region has a long and intensive habitation history, where agriculture played an important role since the onset of the Neolithic period (Nielsen and Odgaard, 2010). This leads to a situation where many climate proxies such as pollen records are difficult to interpret due to the interference between man and the natural vegetation (Berglund, 2003; Zolitschka et al., 2003). The microphenological $\mathrm{UI}$, however, is not affected by human activities, but solely responds to changes in the physical habitat.

The UI analysis provides well-calibrated GDD values through time for this site;

We test to what extent the time-series record corresponds with temperature changes and seasonal dynamics from the wider region, focussing on southern- 
Scandinavia where earlier studies provide mainly summer temperature records (Edwards et al., 2017; Luoto et al., 2017; Zawiska et al., 2017; Zhang et al., 2016).

We moreover evaluate the observed changes in growing season $\mathrm{GDD}_{5}$ against potential forcing mechanisms that have been proposed.

\subsection{Materials and Methods}

\subsubsection{Site description}

Lille Gribsø, $\left(55^{\circ} 59^{\prime} 00.0^{\prime \prime} \mathrm{N} 12^{\circ} 18^{\prime} 53.9^{\prime \prime} \mathrm{E}\right.$, ca $50 \mathrm{~m}$ above sealevel, figure $\mathbf{6 . 1 \mathrm { a }}$, is a small kettle hole lake located in Gribskov forest on Sealand in Eastern Denmark. The lake is characterised by a broad zone of quaking bog composed of several Sphagnum species, the lake has low conductivity, high acidity is oligotrophic and is characterised more by dy than by gyttja (Nygaard, 1977). Nearby lies the larger lake Store Gribsø where pollen-based reconstructions of the surrounding vegetation reveals that the vegetation composition was relatively stable for the last 3000 years since the sand and clay-rich Weichselian moraine landscape area was not particularly suitable for agricultural activities (Nielsen and Odgaard, 2010). The present-day vegetation surrounding the lake is mainly dominated by Fagus sylvatica, Betula pendula, Betula pubescens, Picea abies, Sorbus aucuparia and Quercus robur. Betula pubescens trees grow near the edge of the lake while species from the other genera grows on more dry land. The continuous presence of $B$. pubescens in the area and well-preserved leaf remains in the lake sediments from the early Holocene onwards (Wagner, 1999; Wagner et al., 2002) makes the site suitable for reconstruction of $\mathrm{GDD}_{5}$ based on morphological features of $B$. pubescens epidermal cells.

\subsubsection{Core Description and Sampling}

Two sediment cores were collected in 2004 from the margin of Lille Gribsø. The collected cores LG3 and LG4 are shown in figure 6.1. The end of the top core, LG3 marks the beginning of the second core, LG4. LG3 $(0-110 \mathrm{~cm})$ consists of loose dark-brown organic-rich gyttja or possibly dy where especially the top $10 \mathrm{~cm}$ were weakly compacted. LG4 $(110-232 \mathrm{~cm})$ continues with dark-brown organic-rich gyttja increasingly consolidated towards the lowest part of the section. Certain parts of the core are rich in leaves, with densely packed leaf fragments contributing up to approximately $50 \%$ of the sediment layers. Such leaf packages are especially

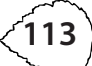


pronounced between $215-232 \mathrm{~cm}$ and $110-122 \mathrm{~cm}$ core depth.

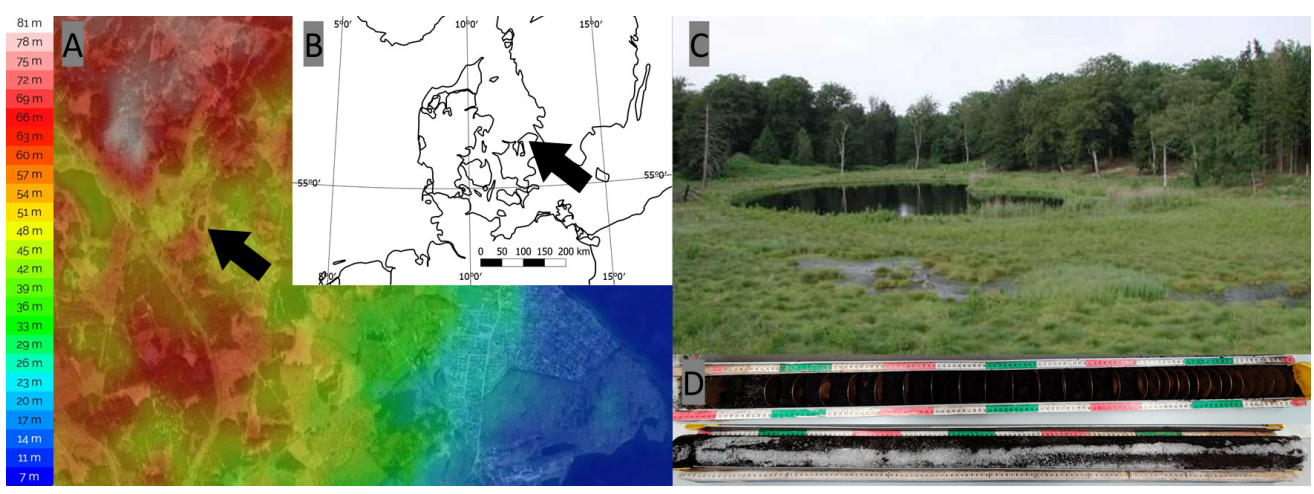

Figure 6.1: (a) The core location of Lille Gribsø is located on a moraineridge at $\sim 50 \mathrm{~m}$ above mean sea level (Yamazaki et al., 2017). (b) Wider geographical context of the core site, on Sealand, north of Copenhagen. (c) Altitude map in $\mathrm{m}$ above sealevel of Lille Gribsø and surroundings, retrieved from Naturstyrelsen. (d) LG3 0-110 cm (top) and LG4 110-232 cm (bottom).

\subsubsection{Core Description and Sampling}

Two sediment cores were collected in 2004 from the margin of Lille Gribsø. The collected cores LG3 and LG4 are shown in figure 6.1. The end of the top core, LG3 marks the beginning of the second core, LG4. LG3 $(0-110 \mathrm{~cm})$ consists of loose dark-brown organic-rich gyttja or possibly dy where especially the top $10 \mathrm{~cm}$ were weakly compacted. LG4 $(110-232 \mathrm{~cm})$ continues with dark-brown organic-rich gyttja increasingly consolidated towards the lowest part of the section. Certain parts of the core are rich in leaves, with densely packed leaf fragments contributing up to approximately $50 \%$ of the sediment layers. Such leaf packages are especially pronounced between $215-232 \mathrm{~cm}$ and $110-122 \mathrm{~cm}$ core depth.

The cores were stored at $-18^{\circ} \mathrm{C}$ and were defrosted overnight at room temperature in order to sample. To prevent mixing of the original layering, the cores were kept horizontally. The cores were divided into slices of $10 \mathrm{~cm}$ (top slice), $5 \mathrm{~cm}$ (at 10-80 $\mathrm{cm}$ depth) and $2 \mathrm{~cm}(80-232 \mathrm{~cm})$ and subsequently stored at $4^{\circ} \mathrm{C}$. Ice segregation partially affected the core and thawing of the weakly compacted deposits in the uppermost part of the core hampered detailed analysis of the core material in the upper $10 \mathrm{~cm}$ of recently deposited organic material. 


\subsubsection{Age assessment}

The chronology of the sediment sequence is based on AMS-radiocarbon dating of terrestrial organic material samples originating from six layers distributed through LG3 \& LG4 see table 6.1. For the construction of the age-depth model, the CLAM package (Blaauw and Christeny, 2011) for the statistical language R (R Core Team, 2020) was used.

Table 6.1: Horizon depth and radiocarbon dated age of organic material from the six horizons form LG3/LG4 from Lille Gribsø.

\begin{tabular}{|l|l|l|l|l|}
\hline Depth & $\begin{array}{l}\text { Radiocarbon } \\
\text { Age B.P. }\end{array}$ & Material & $\begin{array}{l}\text { Sample Code } \\
\text { (BetaAnalytic) }\end{array}$ & $\begin{array}{l}\text { Calibrated Age } \\
\text { (Common Era) }\end{array}$ \\
\hline $60-65$ (LG3) & $260+/-30$ & $\begin{array}{l}\text { One needle and } \\
\text { two and a half } \\
\text { Betula seeds }\end{array}$ & Beta - 549921 & $1695-1656$ \\
\hline $\begin{array}{l}114-116 \\
\text { (LG4) }\end{array}$ & $850+/-30$ & $\begin{array}{l}\text { Betula seeds and } \\
\text { scales }\end{array}$ & Beta - 549922 & $1278-1267$ \\
\hline $\begin{array}{l}124-126 \\
\text { (LG4) }\end{array}$ & $\begin{array}{l}2110+/-30 \\
\text { (Rejected) }\end{array}$ & $\begin{array}{l}\text { Betula seeds and } \\
\text { one scale }\end{array}$ & Beta - 549923 & $\begin{array}{l}1232-1225 \\
\text { (based on depth) }\end{array}$ \\
\hline $\begin{array}{l}160-162 \\
\text { (LG4) }\end{array}$ & $930+/-30$ & $\begin{array}{l}\text { Two Betula } \\
\text { seeds and leaf } \\
\text { fragments }\end{array}$ & Beta - 549924 & $1147-1142$ \\
\hline $\begin{array}{l}216-218 \\
\text { (LG4) }\end{array}$ & $1140+/-30$ & $\begin{array}{l}\text { Two Fagus leaf } \\
\text { fragments }\end{array}$ & Beta - 549925 & $864-844$ \\
\hline $\begin{array}{l}224-226 \\
\text { (LG4) }\end{array}$ & $1360+/-30$ & $\begin{array}{l}\text { One Vaccinium } \\
\text { leaf }\end{array}$ & Beta - 549926 & $779-757$ \\
\hline
\end{tabular}

\subsubsection{Leaf Analysis}

About half of every sampled core layer was sieved over mesh width $0.3 \mathrm{~mm}$ under tap water. From residues, macro-remains were picked and stored separately. B. pubescens leaf fragments were mounted in water on microscopic slides and photographed under a fluorescence microscope setup (microscope: Leica DM6000B, camera: Leica DF310 FX camera at fluorescence setting 13). The taxonomic determination of $B$. pubescens was performed via the stomatal size measurements following the results of Wagner et al. (2000). For each leaf, 1 to 4 pictures of the leaf epidermis (depending on the preservation quality and size of the leaf) were taken at 20x magnification. From these photographs the edges or apex of leaves were excluded since epidermal cells in those regions are not temperature-sensitive in terms of morphology response, the rest was analysed. 
Cell Area $\left(C A, \mu m^{2}\right)$, Cell Circumference $(C C, \mu m)$ and Stomatal Length $(S L, \mu m)$ were analyzed on a minimum of 15 and an average of about 17 epidermal cells with ImageJ 1.52a. on digital cuticle images. From the CA and CC measurements, the Undulation Index (UI) was calculated per leaf fragment (Equation 6.1, Figure 6.2). The resulting values for the UI were then converted to GDD 5 (Equation 6.2) using the model developed for the correlation of UI an GDDs for this species (Ercan et al., 2020). GDD 5 is the cumulative sum of degree Celsius, where a 5 degrees threshold is commonly used as baseline in Fennoscandia (Carter, 1998). The formula for the Ercan et al. (2020) inference model is given as equation 6.3.
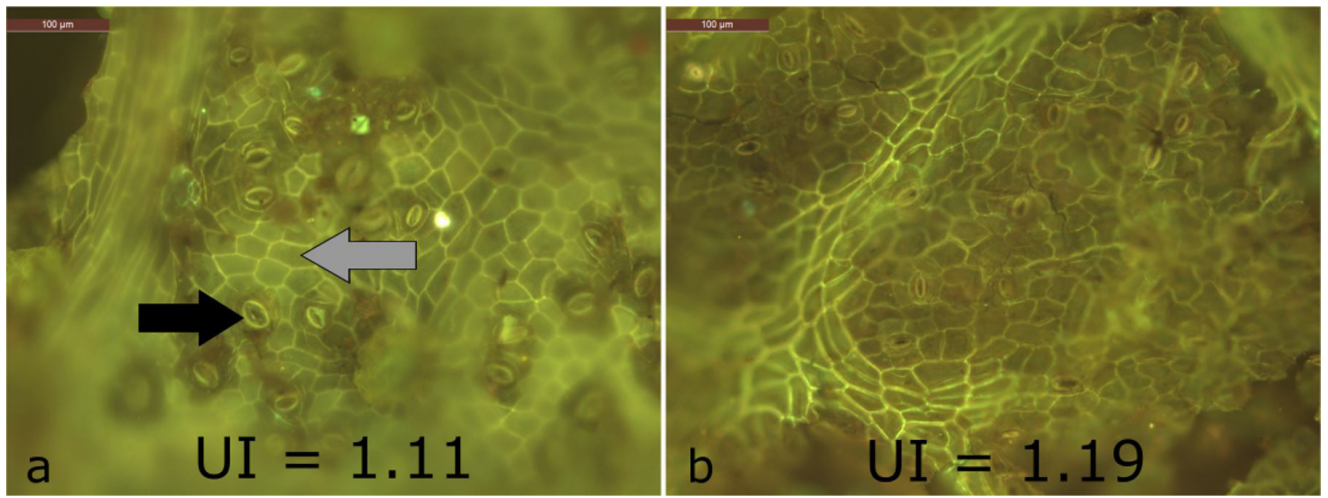

Figure 6.2: Fluorescent microscopy pictures of B. pubescens from Lille Gribsø with Stomata cells (black arrow) and epidermal cells (grey arrow) visible, epidermal cells with low (a) and high (b) UI. Occurrence of lower UI (less developed/undulated epidermal cells) generally indicates a colder or shorter growing season in contrast to higher UI (more developed/undulated epidermal cells), indicating warmer or longer growing conditions.

To compensate systematic offsets in determining GDD5 from UI based on the Fennoscandian model, the data are recalibrated against instrumentally measured $\mathrm{GDD}_{5}$ from the Sealand area. This procedure is preferred over z-scoring since accurate local instrumental data are available. To retrieve $\mathrm{GDD}_{5}$ values appropriate to the Lille Gribsø area, the intercept component of the linear model was altered, by adding the amount of offset in $\mathrm{GDD}_{5}$ between the original model outcomes and the overlapping historical temperature measurements from the nearest metereological station with a long historical record of daily temperature measurements ["KOEBENHAVN: LANDBOHOJSKOLEN-1" 55.68N, 12.53E; 36,5 km from Lille Gribsø; retrieved from climateexp.knmi.nl] (Menne et al., 2012; Trouet and Van Oldenborgh, 2013). There was an average offset of $942.70 \mathrm{GDD}_{5}$ in the 
reference period of (1879-1965), by which the original intercept component was increased.

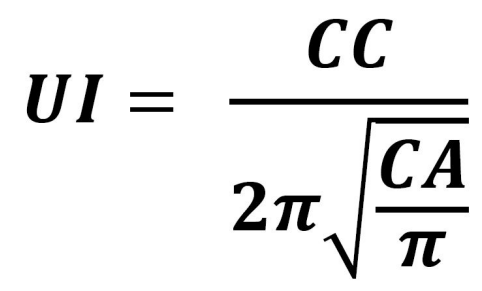

Equation 6.1: Equation for the calculation of the undulation index (UI) based on the mean circumference (CC) and the mean area (CA) of the epidermal cells (Kürschner, 1997).

$$
G D D_{X}=\sum_{i=1}^{\# \text { days }}\left(T_{i}-X\right), \quad T_{i} \geq X
$$

Equation 6.2: $G_{D D}$ covers the growing potential for vegetation in a given year and is expressed by the cumulative sum of degrees Celsius above a determined base temperature (X) (McMaster and Wilhelm, 1997; Weijers et al., 2013) where Ti is the daily mean temperature for day $i$ and $X$ is the selected threshold temperature in degrees Celsius. For Ti, the daily mean temperature from each station was used. For the latitudinal range covered in this study, $5^{\circ} \mathrm{C}$ is the commonly used threshold temperature for plant growth and was taken as threshold temperature $\mathrm{X}$, resulting in $\mathrm{GDD}_{5}$ (Carter, 1998).$$
G D D_{5}=7744.8[U I]-8086
$$

Equation 6.3: Equation for inference of $\mathrm{GDD}_{5}$ from the Undulation Index (UI) of B. Pubescens epidermal cells. Growing Degree Days are interpreted as days with a mean temperature higher than the threshold temperature of 5 degrees Celcius (Ercan et al., 2020). 


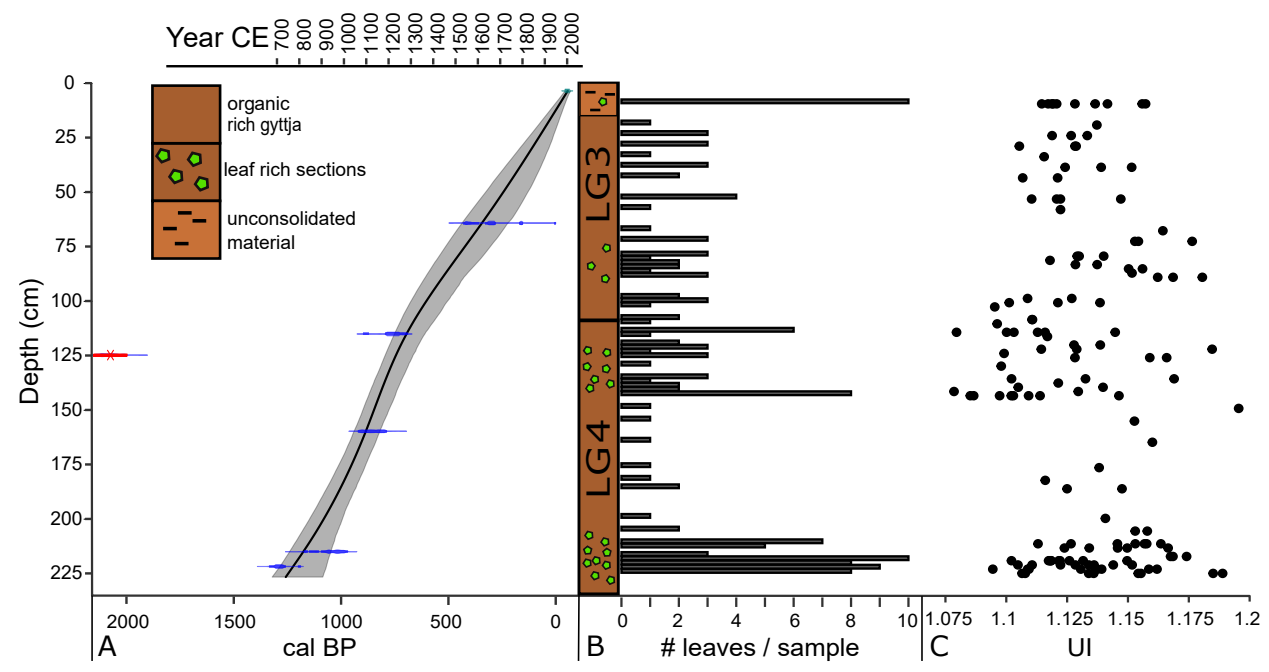

Figure 6.3: (a) Lille Gribsø age-depth model (red line at $125 \mathrm{~cm}$ indicating rejected radiocarbon date) with, (b) core lithology and the number of leaf fragments per sample depth and (c) UI measurements per leaf on each depth. In total, 50 B. pubescens leaf fragments were extracted from LG3 and 96 from LG4 summing to 146 leaf fragments.

\subsection{Results}

\subsubsection{Lille Gribsø GDD5 reconstruction}

The results of the C14 dating are shown in table 6.1. The age for depth 124-126 was identified as an outlier based on the age of $2110+/-30$, which is much older than the layers beneath and was therefore excluded from the age model. This layer has possibly been disturbed during deposition of older material in the sediment column and is excluded from the age model. The constructed age model is shown in figure 6.3.

The age assessment, as constructed with the age-depth model (Figure 6.3a) based on radiocarbon-dated leaf fragments, shows a logical progression where the relation between age and depth spanning about 1300 years, from approximately $691 \mathrm{CE}$ in the lowermost part of the section $(232 \mathrm{~cm})$ to $2004 \mathrm{CE}$ (top $10 \mathrm{~cm}$ ). From this interval, 146 leaf fragments were retrieved, where most of the years with data points were represented by more than one data point (Figure 6.3b). The leaf rich intervals contain up to 10 fragments per sampled $2 \mathrm{~cm}$ horizon, while 
the remaining part is holding lower of fragments per horizon. A high number of data points is centred around the periods of 1171-1356 CE and 691-900 CE with 81 out of the total of 146 data points (55\%) at these time intervals. An even higher concentration of data points was obtained between 691-757 CE, with 35 data points ( $24 \%$ of the total). It is moreover evident that the sections with high leaf abundances are characterised by leaves with low UI values (Figure 6.3c).

The reconstructed $\mathrm{GDD}_{5}$ values for Lille Gribsø that results from the $B$. pubescensbased UI-GDD5 inference model are subsequently plotted against age (Figure 6.4a). The overall reconstructed GDD5 values range from $1209 \mathrm{GDD}_{5}$ to 2115 GDD5. Around 1600, 1450, 1280, 1180 and 780 CE, relatively high peaks of above 1900 $\mathrm{GDD}_{5}$ in individual data points can be distinguished. Between 1150-1400 CE, some data points represent years with exceptionally low values as low as 1209 GDDs. Between 900-1200, the resolution of the record is relatively low and between 1600-1700 CE, where some intervals only contain one or two data points, while the rest is barren. In the section of the core representing 900-1120 CE organic material, in general, was sparsely present. In the record, a phase with low GDD5 is present between 691 CE and 775 CE, followed by the warmer phase 755 CE - 1150 CE. We observe a clear cooling phase between 1175 CE - 1350 CE, followed by even colder values between $1425 \mathrm{CE}$ - $1500 \mathrm{CE}$, a short relative warm period between $1515 \mathrm{CE}$ - 1615 CE and a continuation of cold values between 1700 CE - 1875 CE. After 1875, $\mathrm{GDD}_{5}$ increases towards the present.

The obtained GDD5 record is compared to the tree-ring based record of Zhang et al. (2016), based on analysis of Pine tree-ring data (850-2011CE) from central Scandinavia (Figure 6.4b). 


\section{Chapter 6}

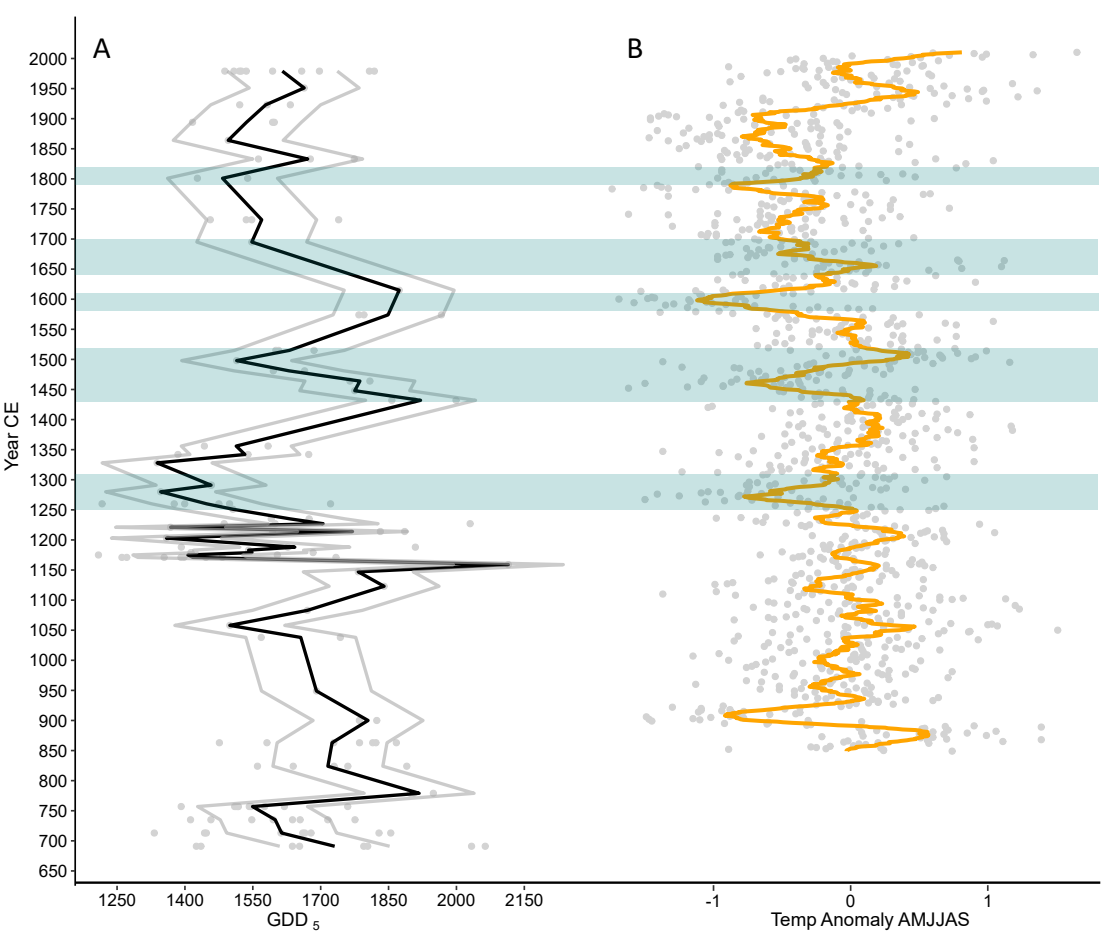

Figure 6.4: (a) Lille Gribsø GGD5-reconstruction (black line represents the average value per time slice, grey lines indicate average plus and minus standard deviation) compared against (b) MXDbased Central Scandinavian April through September temperature anomaly (Zhang 2016). The 20-year smoothing (orange) on the Zhang et al. record allows for comparison to the average time covered in $2 \mathrm{~cm}$ time slices in the LG core. Turquoise overlays: volcanic-solar downturns (Ahmed et al., 2013) on 1251-1310, 1431-1520, 1581-1610, 1641-1700 and 1791-1820 CE. 
Spring temperature changes during the last 1300 years based on Betula pubescens leaves from Denmark

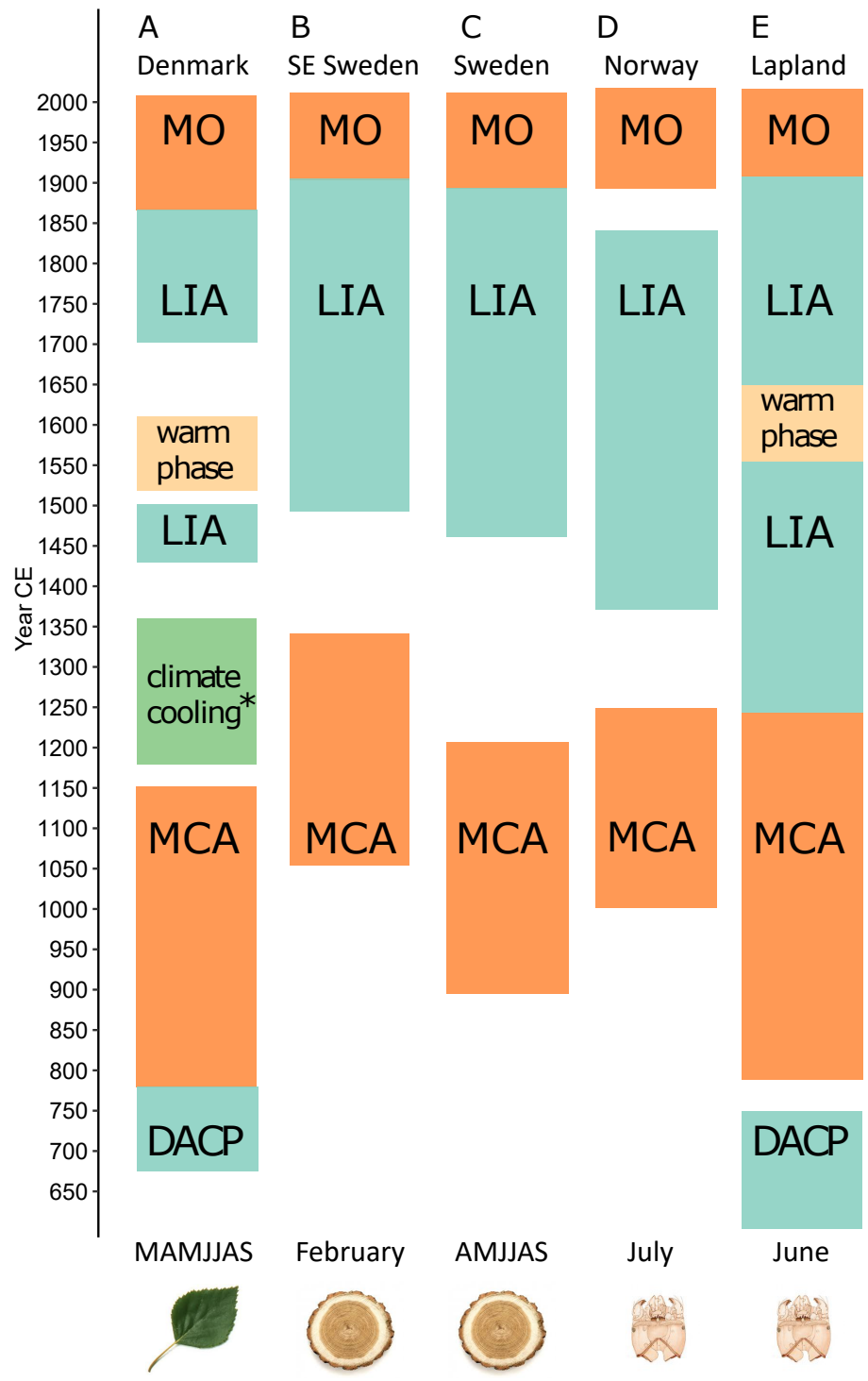

Figure 6.5: Lille Gribsø climatic phases compared to climatic phases in other studies. (a): Birch leaf based proxy, Lille Gribsø (Sealand, Denmark), sensitive throughout the growing season (March through September). (b): Treering based proxy, South Eastern Sweden, mainly sensitive to February temperature fluctuations (Edwards et al., 2017). (c): Treering based proxy, Sweden, sensitive throughout the growing season (April through September) (Zhang et al., 2016). (d): Chironomid based proxy, Norway, sensitive to July temperature fluctutations (Zawiska et al., 2017). (e): Chironomid based proxy, Lapland, sensitive to June temperature fluctuations (Luoto et al., 2017). Climatic phase acronyms: DACP (Dark Age Cold Period), MCA (Medieval Climate Anomaly), LIA (Little Ice Age), MO (Modern Optimum). * "Climate Cooling" phase in the Lille Gribsø record is possibly based on slumping of older material in to the cored deposits, see discussion. 


\subsection{Discussion}

The reconstruction of $\mathrm{GDD}_{5}$ changes from $691 \mathrm{CE}$ - to present reveals significant changes in thermal properties of the growing season in Denmark. The results provide information on the applicability of UI studies with B. pubescens and allow analysis of observations in a regional context as well as the link to known societal dynamics of the last 1300 years.

\subsubsection{GDD $\mathrm{G}_{5}$ reconstruction in Lille Gribsø}

The $\mathrm{GDD}_{5}$ reconstruction for Lille Gribsø implements for the first time a newly developed modern training set for $B$. pubescens based on latitudinal leaf collections over Finland (Ercan et al., 2020). The inference model covers a UI range from $<1.12$ to 1.23 and therewith the range also measured on the fossil leaf remains employed in the present study. The inference of $\mathrm{GDD}_{5}$ data directly from the published Finnish training set, however, is hampered by a systematic offset in the UI/GDD5 relation that was determined through testing against the instrumental GDD5 record available from Copenhagen. After this correction, the calculated GDD5 values are matching the seasonal thermal regime for the study region well. The cause for the systematic offset is difficult to determine and it may relate either to analytical differences (Wagner-Cremer et al., 2010) or the large quantity of B. nana dominated mountain birch hybrids included in the Finnish training set. Although the overall responsiveness in $B$. nana and $B$. pubescens is highly comparable, $B$. nana is preferably treated separately (Wagner-Cremer et al., 2000; Ercan et al., 2020). Despite these remaining uncertainties, the systematic offset neither affects the temporal pacing nor the direction of temperature changes in this pure $B$. pubescens record. Nonetheless, the results also show the need to develop an additional training set based on B. pubescens, only.

To further evaluate the UI derived $\mathrm{GDD}_{5}$ record from Lille Gribsø the results are compared to other proxy records for seasonal temperature available for the region. April through September temperature anomalies are available from maximum latewood density (MXD) analysis in pines from central Scandinavia (Zhang et al., 2016). This annually resolved record shows good agreement in terms of the pacing of short-term temperature fluctuations with our reconstruction for the more southern Lille Gribsø locality, and hints towards the regional character of spring dynamics. The Zhang et al. study uses maximum latewood density (MXD) X-ray technique that is a proxy sensitive to temperature variations in the April - September portion 
of the growing season, the part of the growing season (March-September) also covered by the UI proxy presented in this study. The annual resolution obtained in the tree-ring record provides a good measure for the extend of variability that can be expected in the results of the present study where the examined sediment sections comprise multiple years per sample. The tree-ring data reveal strong yearto-year differences which implies that a certain degree of scattering observed in the $\mathrm{UI}$ record might relate to the averaging of the $4-10$ years per sample resolution reached in our study. Both records reveal reoccurring phases of colder conditions that supports the ideas raised by the PAGES $2 \mathrm{k}$ initiative where climate cooling is triggered by a combination of decreased solar activity and pulses of volcanic forcing during the last millennium (Ahmed et al., 2013).

\subsubsection{Lille Gribsø in the regional context}

The GDD5-based temperature fluctuations present in the LG record closely compare to known temperature oscillations from the Northern Hemisphere. Based on the GDD record, periods with consistent patterns are subsequently coupled to known climatic phases for the past 1300 years (Figure 6.5).

The oldest part of the record (691 - $775 \mathrm{CE}$ ) represents a relative cool phase associated with the Dark Age Cold Period (DACP) where we observe continuously low $\mathrm{GDD}_{5}$ values in the lowermost section of the core. In this section of the core, we observe a large amount of leaves, which could be connected to the lower GDD5 values, possibly through better preservation in colder conditions.

After 775 CE GDD5 increases rapidly by more than $300 \mathrm{GDD}_{5}$ within just a few years and remains on a relatively stable level until 1150 CE demarking the warmer Medieval Climate Anomaly (MCA).

We observe a turbulent cooling trend leading up to the LIA between 1175 - 1350 $\mathrm{CE}$, this phase is characterised by a high amount of data points. This phase is feasibly suspected of originating from an intrusion or slumping of older material, this would account for the rejected radiocarbon age (Table 6.1). If this is the case, it would explain the difference between the findings in our observations and the other records where a higher temperature is reconstructed for these dates. The low amount of available leaves in the period directly preceding this phase could be caused by oxidation, caused by a hypothetical water level lowering event at the end of the MCA, triggering slumping of older material into the sediment at the 
core location.

After the phase between 1175 - $1350 \mathrm{CE}$, the climate reached continuous cool conditions in the first phase of the LIA between 1425 - 1500 CE. A short relative warm phase occurs between 1515 - 1615 CE leading up to the second LIA cold phase between 1700 - 1875 CE. The successive increase in GDD5 after 1875 coincides with the warming towards the modern climate optimum.

The distinguished phases of alternating warmer and cooler conditions have been noted in several studies implementing various proxies. These records are providing data for individual summer month's temperature or winter temperature, with only the MDX record capturing the larger parts of the growing season (Zhang et al. 2016).

In terms of climatic anomalies, the DACP is only present in the Luoto et al. (2017) record, where it ends around the same time as in the Lille Gribsø record. The DACP is not named as a separate climate anomaly by Luoto et al. (2017) but is recognized as a cooling period following the Roman Warm Period (not shown in figure 6.5) until 750 CE in Northern Lapland. The ending of this cooling period corresponds with the ending of the DACP in the Lille Gribsø record.

The MCA is present in all four other records and seems to end later than in the Lille Gribsø record. The beginning of the MCA is limited by the length of the reconstructions, except for Luoto et al. (2017), that extends further back in time than the Lille Gribsø record. In Luoto et al. (2017), the MCA is recognised as warmer than the Roman Warm Period, having an increase in summer temperatures from $800 \mathrm{CE}$ onwards. Zhang et al. (2016) recognizes elevated growing season temperatures in Sweden from 900 to 1200 CE, with a warm peak from 1000 - 1100 CE. The Zawiska et al. (2017) record starts at $1000 \mathrm{CE}$, showing elevated summer temperatures in Norway with a cooling phase around 1050-1150 CE, and warming again from 1150 to 1250 CE. In Edwards et al. (2017), the MCA in South Eastern Sweden is separated in an early (1050-1250 CE) and a late (1250-1350 CE) phase, where the earlier period is characterized by high (winter) temperatures and high (summer) relative humidity where the late phase is characterized by reduced temperature with continued high relative humidity.

The onset of the LIA varies between records, but there is consensus on there being a phase of more turbulent climate variability, slowly turning into the LIA, often 
interrupted by a short phase of warming, continuing, and climaxing in a colder phase. Luoto et al. (2017) recognise two periods of colder summer temperatures, from $1250 \mathrm{CE}$ to $1550 \mathrm{CE}$ and from $1650 \mathrm{CE}$ to $1900 \mathrm{CE}$, with a warmer phase between them. In Zawiska et al. (2017), cooler summers are recognized in Norway between 1370 CE and 1850 CE. According to the Zhang et al. (2016) MDX record, reflecting growing season temperatures in Sweden, a cooling event took place around $1450 \mathrm{CE}$, leading up to a cooler phase from $1550 \mathrm{CE}$ to $1900 \mathrm{CE}$. Edwards et al. (2017) distinguish between two phases in South-East Sweden where in the early phase (1500-1650 CE), declining winter temperatures and declining summer relative humidity have been noticed. In the later phase (1650-1900 CE), oscillating winter temperatures are noted while relative humidity rises in summer.

All records agree on the termination of the LIA, turning into the modern climate optimum around 1900.

Besides temperature, humidity and precipitation also play an important role in climatic shifts in relation to socio-economic impact. However, there are still large unknowns revolving around the contributing factors of atmospheric and oceanic circulation patterns to North Atlantic and European summer droughts, while they are heavily influencing societies via crop yield and failures (Büntgen et al., 2021). As mentioned, Edwards et al. (2017) noted several trends in humidity in addition to temperature trends over the last millennium CE. The UI-proxy could contribute to knowledge about humidity patterns in the past, as UI is also sensitive to extreme droughts, albeit that this must be further parametrised and constrained in future research to function as humidity proxy.

In addition to environmental consequences, changes in growing season properties have a profound impact on the development of human societies as crop failures resulting from the decline of the growing season intensity have been connected to famines, migration, pandemics, wars, and declining populations (Benati and Guerriero, 2021; Degroot et al., 2021; Ljungqvist et al., 2021b). Cereals has been the most important source of food in Europe in centuries, affecting the entire economy (Ljungqvist et al., 2021b), and the link between climate and grain price helps to understand the influence of climate on the course of history. Reconstructed temperature has been linked to grain price (Nordli et al., 2003), and grain price in turn to building activity for example (Ljungqvist et al., 2021b). Climate change, in general, has been linked with agricultural production index, grain price, real wages, body height index, crisis's and population size (Zhang et al., 2011). New 
information regarding climatic shifts, particularly focusing on seasonality changes, in the Zealand region over the last $\sim 1300$ years as presented in this paper sheds new light on possible climatic causes for social, economic, and historic developments during that time. These developments include the end of the Germanic Iron Age, the Viking Age (793-1066 CE), the Scandinavian Middle Ages (1066-1536 CE), Scandinavian Reformation and the onset of industrialization. The record allows for anecdotal examples of historic events with weather or climate related causes to be linked to corresponding fragments of our record, like the crossing of a Swedish invasion army into Denmark over the frozen inner Danish waters in 1658, fitting well with a minimum in the LG record.

\subsection{Conclusion}

This UI based Growing Season proxy record, spanning roughly 1300 years, is the first record of such length for Denmark. The complete record agrees with comparable records from the Scandinavian region in order and timing of climatic shifts from warmer to colder phases, like the Dark Age Cold Period, Medieval Climatic Anomaly, Little Ice Age, and the onset of the Modern Optimum. The record allows for a link between climatic shifts and societal impact through direct relevance to agriculture.

\subsection{Acknowledgements}

The authors thank Bent Aaby and Morten Fischer Mortensen for their expert feedback on this manuscript. 


\subsection{Literature}

Ahmed M, Anchukaitis KJ, Asrat A, Borgaonkar HP, Braida M, Buckley BM, et al. (2013) Continentalscale temperature variability during the past two millennia. Nature Geoscience 6(5): 339-346: doi:10.1038/ngeo1797.

Benati G and Guerriero C (2021) Climate change and state evolution. Proceedings of the National Academy of Sciences of the United States of America 118(14): 1-5: doi:10.1073/pnas.2020893118.

Berglund BE (2003) Human impact and climate changes - Synchronous events and a causal link? Quaternary International 104: 7-12: doi:10.1016/s1040-6182(02)00144-1.

Blaauw M and Christeny JA (2011) Flexible paleoclimate age-depth models using an autoregressive gamma process. Bayesian Analysis 6(3): 457-474: doi:10.1214/11-BA618.

Büntgen U, Urban O, Krusic PJ, Rybníček M, Kolář T, Kyncl T, et al. (2021) Recent European drought extremes beyond Common Era background variability. Nature Geoscience: doi:10.1038/s41561-02100698-0.

Carter TR (1998) Changes in the thermal growing season in Nordic countries during the past century and prospects for the future. Agricultural and Food Science 7(2): 161-179: doi:10.23986/afsci.72857.

Degroot D, Anchukaitis K, Bauch M, Burnham J, Carnegy F, Cui J, et al. (2021) Towards a rigorous understanding of societal responses to climate change. Nature. Springer US 591(7851): 539-550. Available at: http://dx.doi.org/10.1038/s41586-021-03190-2: doi:10.1038/s41586-021-03190-2.

Edwards TWD, Hammarlund D, Newton BW, Sjolte J, Linderson H, Sturm C, et al. (2017) Seasonal variability in Northern Hemisphere atmospheric circulation during the Medieval Climate Anomaly and the Little Ice Age. Quaternary Science Reviews. Elsevier Ltd 165: 102-110. Available at: http:// dx.doi.org/10.1016/j.quascirev.2017.04.018: doi:10.1016/j.quascirev.2017.04.018.

Ercan FEZ, De Boer HJ and Wagner-Cremer F (2020) A growing degree day inference model based on mountain birch leaf cuticle analysis over a latitudinal gradient in Fennoscandia. Holocene 30(2): 344-349: doi:10.1177/0959683619865605.

Gouw-Bouman MTIJ, van Asch N, Engels S and Hoek WZ (2019) Late Holocene ecological shifts and chironomid-inferred summer temperature changes reconstructed from Lake Uddelermeer, the Netherlands. Palaeogeography, Palaeoclimatology, Palaeoecology. Elsevier 535(September): 109366. Available at: https://doi.org/10.1016/j.palaeo.2019.109366: doi:10.1016/j.palaeo.2019.109366.

Huhtamaa H and Helama S (2017) Reconstructing crop yield variability in Finland: Long-term perspective of the cultivation history on the agricultural periphery since ad 760 . Holocene 27(1): 3-11: doi:10.1177/0959683616646188.

Kelley CP, Mohtadi S, Cane MA, Seager R and Kushnir Y (2015) Climate change in the Fertile Crescent and implications of the recent Syrian drought. Proceedings of the National Academy of Sciences of the United States of America 112(11): 3241-3246: doi:10.1073/pnas.1421533112.

Kürschner WM (1997) The anatomical diversity of recent and fossil leaves of the durmast oak (Quercus petraea Lieblein/ Quercus pseudocastanea Goeppert): implications for their use as biosensors of paleoatmospheric CO2 levels. Review of Palaeobotany and Palynology 96(96): 1-30. 
Ljungqvist F (2010) A Regional Approach to the Medieval Warm Period and the Little Ice Age. Climate Change and Variability (August 2010): doi:10.5772/9798.

Ljungqvist FC, Seim A and Huhtamaa H (2021a) Climate and society in European history. Wiley Interdisciplinary Reviews: Climate Change 12(2): 1-28: doi:10.1002/wcc.691.

Ljungqvist FC, Thejll P, Christiansen B, Seim A, Hartl C and Esper J (2021b) The significance of climate variability on early modern European grain prices. Cliometrica. Springer Berlin Heidelberg. Available at: https://doi.org/10.1007/s11698-021-00224-7: doi:10.1007/s11698-021-00224-7.

Luoto TP, Kivilä EH, Rantala M V. and Nevalainen L (2017) Characterization of the Medieval Climate Anomaly, Little Ice Age and recent warming in northern Lapland. International Journal of Climatology 37(April): 1257-1266: doi:10.1002/joc.5081.

Luterbacher J, Werner JP, Smerdon JE, Fernández-Donado L, González-Rouco FJ, Barropedro D, et al. (2016) European summer temperatures since Roman times. Environmental Research Letters 11(2).

McMaster GS and Wilhelm WW (1997) Growing degree-days: one equation, two interpretations. Agricultural and Forest Meteorology 87(1): 291-300.

Menne MJ, Durre I, Vose RS, Gleason BE and Houston TG (2012) An overview of the global historical climatology network-daily database. Journal of Atmospheric and Oceanic Technology 29(7): 897910: doi:10.1175/JTECH-D-11-00103.1.

Nielsen AB and Odgaard BV (2010) Quantitative landscape dynamics in Denmark through the last three millennia based on the Landscape Reconstruction Algorithm approach. Vegetation History and Archaeobotany 19(4): 375-387: doi:10.1007/s00334-010-0249-z.

Nordli P, Lie, Nesje A and Dahl SO (2003) Spring-summer temperature reconstruction in western Norway 1734-2003: A data-synthesis approach. International Journal of Climatology 23(15): 18211841: doi:10.1002/joc.980.

Nygaard G (1977) New or Interesting Plankton Algae, With a Contribution on their Ecology. Det Kongelige Danske Videnskabernes Selskab Biologiske Skrifter 21,1 21(1): 1-107: doi:10.2307/3753553.

R Core Team (2020) R: A Language and Environment for Statistical Computing. Vienna, Austria: R Foundation for Statistical Computing. Available at: https://www.r-project.org/.

Steinthorsdottir M and Wagner-Cremer F (2019) Hot summers ahead? Multi-decadal spring season warming precedes sudden summer temperature rise in pre-anthropogenic climate change. Gff. Taylor \& Francis 141(3): 175-180. Available at: https://doi.org/10.1080/11035897.2019.1655791: do i:10.1080/11035897.2019.1655791.

Steinthorsdottir M, Wagner-cremer F and Steinthorsdottir M (2019) Hot summers ahead? Multidecadal spring season warming precedes sudden summer temperature rise in pre-anthropogenic climate change summer temperature rise in pre-anthropogenic climate change. GFF. Taylor \& Francis 00(00): 1-6. Available at: https://doi.org/10.1080/11035897.2019.1655791: doi:10.1080/11035897.20 19.1655791.

Trouet V and Van Oldenborgh GJ (2013) KNMI Climate Explorer: A Web-Based Research Tool for HighResolution Paleoclimatology. Tree-Ring Research 69(1): 3-13. Available at: http://www.bioone.org/ doi/abs/10.3959/1536-1098-69.1.3: doi:10.3959/1536-1098-69.1.3. 
Wagner-Cremer F, Finsinger W and Moberg A (2010) Tracing growing degree-day changes in the cuticle morphology of Betula nana leaves: A new micro-phenological palaeo-proxy. Journal of Quaternary Science 25(6): 1008-1017: doi:10.1002/jqs.1388.

Wagner F (1999) Century-Scale Shifts in Early Holocene Atmospheric CO2 Concentration. Science 284(5422): 1971-1973: doi:10.1126/science.284.5422.1971.

Wagner F, Aaby B and Visscher H (2002) Rapid atmospheric CO2 changes associated with the 8,200-years-B.P. cooling event. Proceedings of the National Academy of Sciences of the United States of America 99(19): 12011-12014: doi:10.1073/pnas.182420699.

Wagner F, Neuvonen S, Kürschner WM and Visscher H (2000) The influence of hybridization on epidermal properties of birch species and the consequences for palaeoclimatic interpretations. Plant Ecology 148(1): 61-69: doi:10.1023/A:1009801614786.

Weijers S, Wagner-Cremer F, Sass-Klaassen U, Broekman R and Rozema J (2013) Reconstructing High Arctic growing season intensity from shoot length growth of a dwarf shrub. The Holocene 23(5): 721-731. Available at: http://journals.sagepub.com/doi/10.1177/0959683612470178: doi:10.1177/0959683612470178.

Wilcke RAI, Kjellström E, Lin C, Matei D, Moberg A and Tyrlis E (2020) The extremely warm summer of 2018 in Sweden - Set in a historical context. Earth System Dynamics 11(4): 1107-1121: doi:10.5194/ esd-11-1107-2020.

Yamazaki D, Ikeshima D, Tawatari R, Yamaguchi T, O'Loughlin F, Neal JC, et al. (2017) A highaccuracy map of global terrain elevations. Geophysical Research Letters 44(11): 5844-5853: doi:10.1002/2017GL072874.

Zawiska I, Luoto TP, Nevalainen L, Tylmann W, Jensen TC, Obremska M, et al. (2017) Climate variability and lake ecosystem responses in western Scandinavia (Norway) during the last Millennium. Palaeogeography, Palaeoclimatology, Palaeoecology 466:231-239: doi:10.1016/j.palaeo.2016.11.034.

Zhang DD, Lee HF, Wang C, Li B, Pei Q, Zhang J, et al. (2011) The causality analysis of climate change and large-scale human crisis. Proceedings of the National Academy of Sciences of the United States of America 108(42): 17296-17301: doi:10.1073/pnas.1104268108.

Zhang P, Linderholm HW, Gunnarson BE, Bjorklund J and Chen D (2016) 1200 years of warm-season temperature variability in central Scandinavia inferred from tree-ring density. Climate of the Past 12(6): 1297-1312: doi:10.5194/cp-12-1297-2016.

Zhang P, Linderholm HW, Gunnarson BE, Björklund J and Chen D (2015) 1200 years of warmseason temperature variability in central Fennoscandia inferred from tree-ring density. Climate of the Past Discussions 11(1): 489-519. Available at: http://www.clim-past-discuss.net/11/489/2015/: doi:10.5194/cpd-11-489-2015.

Zolitschka B, Behre K-E and Schneider J (2003) Human and climatic impact on the environment as derived from colluvial, fluvial and lacustrine archives-examples from the Bronze Age to Migration period, Germany. Quaternary Science Reviews 22: 91-100. 


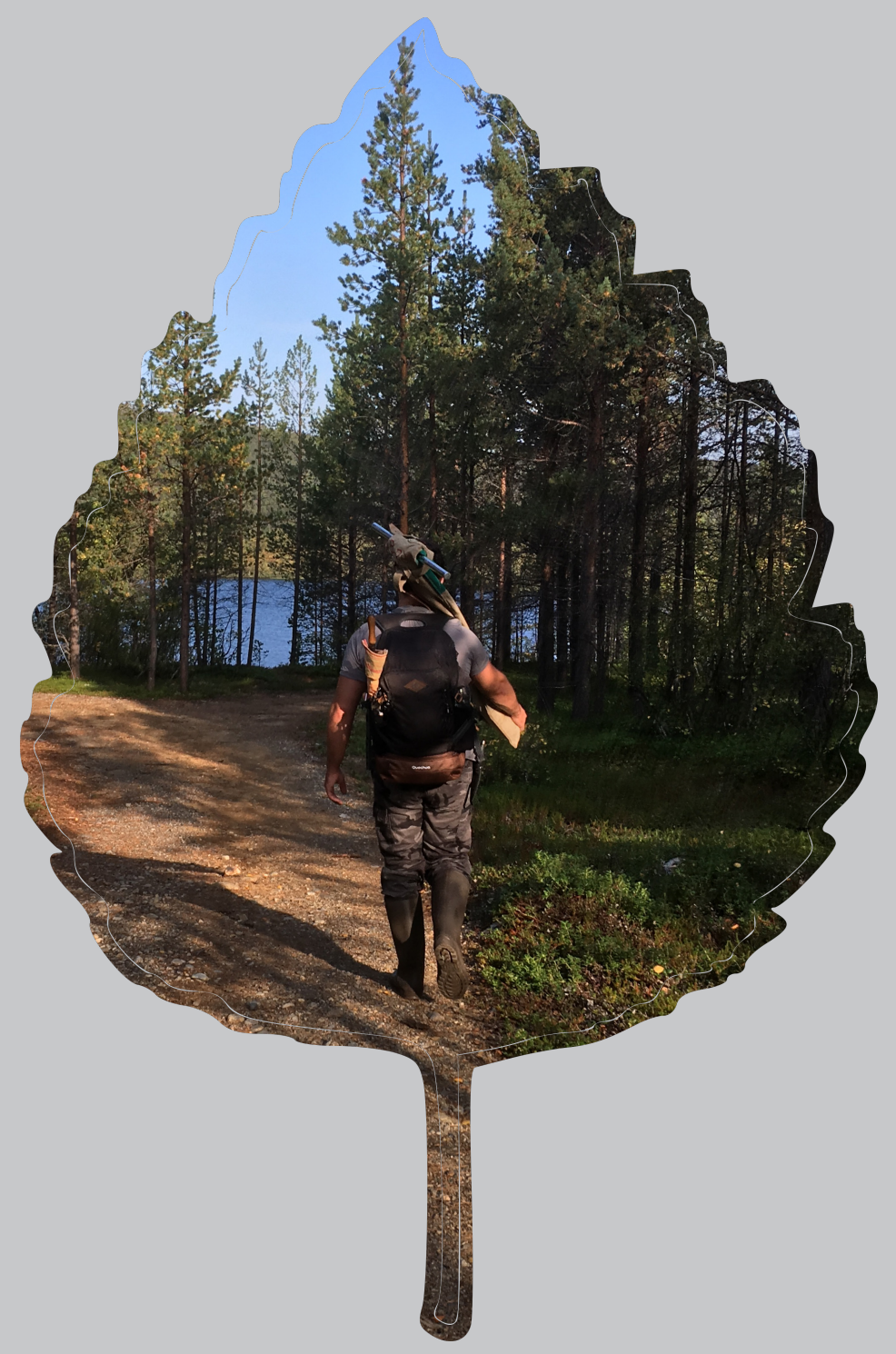




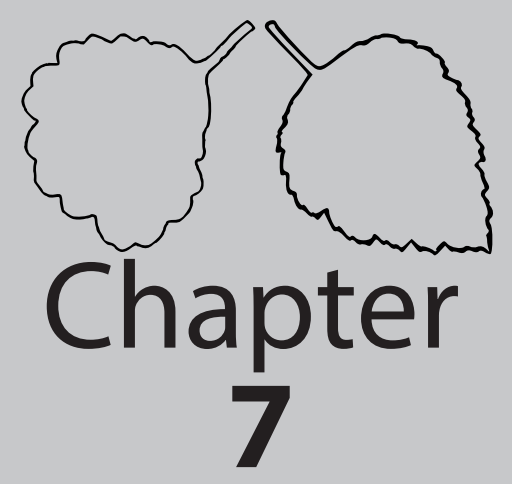




\section{Synopsis}

\subsection{Thesis Summary}

The main goal of this thesis is to provide knowledge on the natural baseline of climate variability in northern high latitudes during pre-industrial times by using a spring-sensitive vegetation-based proxy. Of additional interest is the potential impact of future climate change on early growing season vegetation dynamics.

The following research questions have been addressed in this thesis:

To what extent is the Birch based UI proxy suitable to reconstruct early growing season change in northern high latitudes? (Chapters 2, 3 and 5)

How will Betula nana and Betula pubescens react to future climate warming in terms of increased plant performance? (Chapters 2, $\mathbf{3}$ and 5)

Is the UI proxy suitable to reconstruct NAO dynamics on both sides of its see-saw pattern (Northern-Europe and Western-Greenland)? (Chapter 4)

In terms of Ul-reconstructed early growing season dynamics, how does temperature fluctuate in pre-industrial north-western Europe? (Chapter 6)

In this thesis, data generated by analysis of (fossil) leaf micro-phenology has been calibrated against available historical meteorological data and was validated with in-situ climate manipulation experiments to ensure accurate reconstructions of growing season dynamics. The research focussed on the NAO-sensitive areas of Greenland and Fennoscandia over the last Millennium, giving insight in spring dynamics, supporting understanding of ongoing climate change and its impact on society. 


\subsection{Chapter Summaries}

\section{Chapter 2}

In this chapter the response of epidermal UI of Betula pubescens to GDD on a latitudinal gradient though Fennoscandia was used to establish an inference model. This inference model enables the future use of $B$. pubescens (including $B$. pubescens spp. czerepanovii; mountain birch) UI in GDD reconstructions. By adding mountain birch to the epidermal UI proxy that was previously only available for Betula nana, the temperature range which is covered by the proxy is expanded and now covers growing season temperature regimes characteristic of boreal forest biomes rather than (sub-)arctic conditions only. Enlarging the climatic range has greatly increased the applicability of the UI proxy by allowing reconstructions of broader geographic and temporal contexts. As B. pubescens / B. pubescens spp. czerepanovii follows B. nana in the post-glacial ecological succession, the UI proxy can now moreover be used to further examine naturally occurring climatic shifts during the Quaternary.

\section{Chapter 3}

To test and understand the B. nana epidermal UI proxy, the UI response to GDD was in this chapter compared between experiments in natural settings over a large geographical range. One research site is situated in northern Finland, where $B$. nana enjoys optimal growth in sub-Arctic continental conditions, the second one research site is in western Greenland, where B. nana survives under below-optimal growth in Arctic marine influenced conditions and a third one research site in northern Poland, where $B$. nana occurs in a temperate continental relict stand, a remnant population from glacial times. The research shows the expected response of epidermal UI to experimentally elevated temperatures; $B$. nana produces higher $\mathrm{UI}$ at higher GDD values. In Greenland, however, where growing conditions are hostile to $B$. nana, no differences between UI response to experimental treatments are measured.

\section{Chapter 4}

The response of $B$. nana $\mathrm{UI}$ in Finland and Greenland to North Atlantic Oscillation (NAO) modes confirm the sensitivity of the UI proxy to annually NAO-determined winter and spring conditions, as tested in this chapter. The UI proxy is shown to be sensitive for historically documented and modelled changes in NAO phase and 
intensity, reaching back in time till the 1860's (Common Era), and demonstrates the characteristic "seesaw" relation between the north-western and north-eastern Atlantic. These findings enable the use of B. nana UI derived from herbaria and natural archives (such as peat bogs and lake sediments) as NAO proxy in the future, thereby increasing our understanding of NAO dynamics over the past centuries and help to quantify the future impact of the NAO on plant performance and ecology. These findings highlight the sensitivity of the UI proxy to even annual changes, allowing for very detailed future studies of climatic events in the past.

\section{Chapter 5}

In this chapter, the effectiveness of the B. nana epidermal UI proxy under extreme low temperatures was tested. Using numerical models and geometric logic, the rate of response under extremely low GDD was shown to decline. Although B. nana is present in these very cold areas, like in Greenland, the plant does not perform well compared to northern Finland, where more optimal growth conditions occur. It seems that the applicability of the $B$. nana UI proxy is mainly limited to its optimal habitat. This adds important knowledge on the constraints and applicability of the UI proxy through time and space, where the suitability of the B. nana UI proxy to produce exact GDD results might be limited in the coldest of climatic phases and areas, although fossil B. nana leaf remains may occur.

\section{Chapter 6}

A very complete growing season reconstruction from western Denmark spanning the last 1300 years is presented in this chapter. This detailed record, based on B. pubescens epidermal UI, agrees highly with comparable records of the wider geographical area. Previously, historical periods of societal turmoil have been tentatively linked to either summer or winter temperatures, with the addition of this record based on the spring sensitive B. pubescens UI proxy, there is additional evidence for the link between climate and society. The reconstructed spring dynamics are of large influence on agriculture, and as such have a large impact on agriculture-based societies. As such, this record allows for direct linkage with socio-economic historical events and climatic periods in the region over the last 1300 years. 


\subsection{Future Prospects}

The work shown in this thesis has closed important knowledge gaps concerning the sensitivity and applicability of the UI proxy. From now on, secure proxy records for spring dynamics over a large geographical region can be produced using this proxy. These records can depict even minor climatic swings on a high temporal resolution. Large scale data coverage in future projects can improve our understanding in growing season dynamics, relevant for future projections relating to carbon cycle and hydrology, and societal impact. In future research, the ability to distinguish natural from human-induced climate change will be an important goal. The analysis of certain climatic shifts such as the transition between the Dark Age Cold Period, the Medieval Climatic Anomaly, the Little Ice Age, and the Modern Optimum will be important focus points for setting baseline knowledge about climate shifts in general and specifically to understand anthropogenic influence on current climate change. Seasonal dynamics, especially the onset of spring, are covered by the $\mathrm{Ul}$ proxy, and as such will be of main focus in future research.

The time-consuming nature of applying the $\mathrm{UI}$ proxy comes from the fact that $\mathrm{UI}$ is hand measured by digital drawing. The effort needed to analyse large quantities of data currently form a bottleneck in realising large scale coverage. This bottleneck can potentially be relieved by automatization of the measurement process. Automized analysis with image processing algorithms would greatly increase the production capacity of UI-based growing season reconstructions. One such algorithm is GraVis, currently in development (Nowak et al ,2021). After thorough optimization and calibration of the algorithm based on previously measured epidermal material as input data, GraVis will be able to detect and analyse epidermal cells from microscopy photos and provide output values directly in interpretable format. Automated analysis of UI will allow for much larger datasets, permitting the expansion of UI-based research over a larger geographical area and longer timescales. Additionally, more calibration training sets can be analysed with less effort, allowing for more species to be used as proxy, enabling higher precision and aid in expansion of the UI based proxies in other regions of the world where birch is unavailable. 


\subsection{Literature}

Nowak, J., Eng, R. C., Matz, T., Waack, M., Persson, S., Sampathkumar, A., \& Nikoloski, Z. (2021). A network-based framework for shape analysis enables accurate characterization of leaf epidermal cells. Nature Communications, 12(1), 1-13. https://doi.org/10.1038/s41467-020-20730-y 


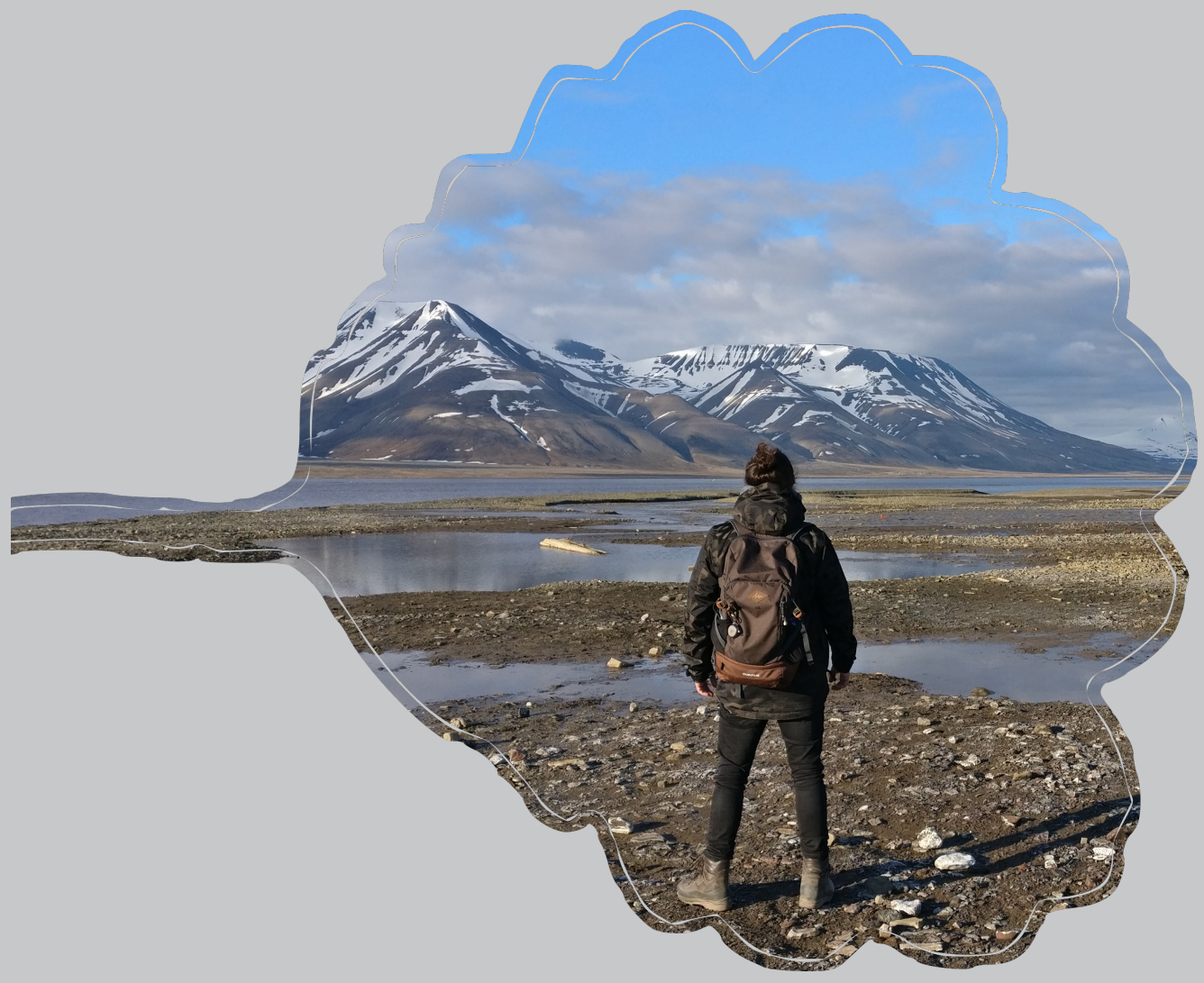




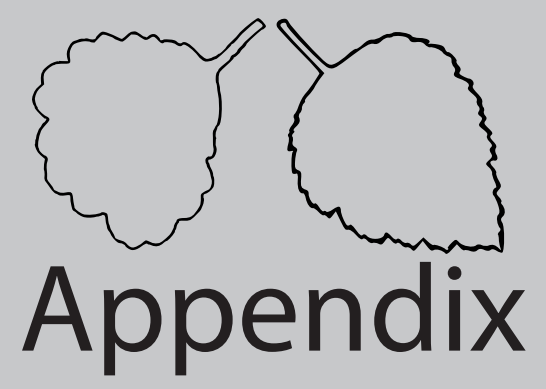




\section{Layman's Summary}

\section{Growing Season Changes over the Past Millennium in Northern High Latitudes}

In recent decades, it has become clear through meteorological observations that the climate is changing. Particularly the spring season is getting warmer and also seems to start earlier. Since in the far north the growing season is shorter than in the temperate latitudes, this advance of spring is more prominent. The ecosystems in the northern areas are thus more vulnerable to this changes in the spring, because many natural processes risk to get out of balance. In order to properly understand these current changes of the growing season, it is necessary to look back in time to the pre-industrial mode of climate. By doing so we can study how the natural dynamics of the spring season manifested themselves before the modern period of warming.

Since there is little to no reliable meteorological data available from before the industrial revolution, we derive the state of the climate of the past from socalled palaeoecological proxies, in this case fossil leaves that act as biological thermometers. With the fossil leaf remains we can reconstruct what the temperature must have been in the past. Before such proxies work properly, they must be soundly calibrated and tested. In this $\mathrm{PhD}$ research, the degree of undulation in the circumference of the cell wall of the epidermal cells of birch leaves was used generate information on the thermal intensity of the growing season, with the advance of spring as main influencing factor. Dwarf birch cell circumference was already established in previous studies as a paleo-thermometer for the growing season. In the present study the downy birch was targeted to broaden the proxy based on the circumference of the leaf cells. In order to achieve this, plant physiological experiments performed in Finland, Poland, and Greenland provided leaf samples grown under natural conditions and artificial warming were studied to determine the exact responsiveness of birch to temperature. The meaningfulness of the proxy has also been demonstrated by proving that it is sensitive to minor annual fluctuations in the large-scale atmospheric system that affects the weather in the areas around the North Atlantic. After validation and testing on modern leaf material and from historical herbarium specimen, the proxy has then been used to reconstruct the intensity of the growing season over roughly the past 1300 years in Denmark, where the fossil leaves samples have been retrieved from lake sediment cores. This study has shown that during the last millennium, the natural changes 140 
in the growing season have been closely linked to the state of prosperity of the population, demonstrating the societal importance of changing seasonality. The strong link between spring season weather on societal and economical welfare in the past clearly shows that this rapidly changing seasonality regime will also have to be considered in discussions of future climate change impacts on our societies. 


\section{Nederlandse Samenvatting Veranderingen van het groeiseizoen gedurende het laatste millennium in het hoge Noorden}

In de afgelopen decennia is het middels meteorologische observaties duidelijk geworden dat het klimaat warmer wordt. Met name de lente wordt steeds warmer en begint steeds vroeger. Aangezien in het hoge noorden het groeiseizoen korter is dan op de gematigde breedtegraden, is deze vervroeging van de lente prominenter aanwezig. Het ecosysteem in de noordelijke gebieden is in de lente kwetsbaarder voor deze verstoring, omdat veel processen in de natuur het risico te lopen om uit balans te raken ten opzichte van elkaar. Om deze huidige veranderingen van het groeiseizoen goed te kunnen begrijpen is het noodzakelijk om terug in de tijd te kijken naar de pre-industriële modus van het klimaat, om te kunnen begrijpen hoe de dynamiek van de vroege lente zich manifesteerde voor de moderne periode van opwarming. Aangezien er nauwelijks tot geen betrouwbare meteorologische gegevens beschikbaar zijn van voor de industriële revolutie, is men genoodzaakt om de staat van het klimaat van het verleden af te leiden uit zogenaamde proxies, in dit geval biologische thermometers. Met de fossiele resten van deze biologische thermometers, zogenoemde proxies, kan men afleiden wat in het verleden bijvoorbeeld de temperatuur geweest moet zijn. Om deze proxies goed te laten werken, moeten deze geijkt en getest worden (hoofdstuk 5). In dit promotieonderzoek is de mate van golving in de omtrek van de celwand van de huidcellen van het blad van berkenbomen gebruikt als proxy voor de intensiteit van het groeiseizoen, waarbij voornamelijk de vervroeging van de lente van invloed is. Van de dwergberk was eerder bekend dat deze proxy op basis van cel omtrek goed werkt. Tijdens dit promotieonderzoek is ook voor de zachte berk vastgesteld dat deze goed fungeert als proxy op basis van omtrek van de bladcellen (hoofdstuk 2). De proxy op basis van deze berkensoorten is toegepast op experimenten in Finland, Polen, en op Groenland met als doel het aantonen dat de vervroeging van de lente de ecologie zal verstoren (hoofdstuk 3). De bruikbaarheid van de proxy is ook aangetoond door te bewijzen dat deze gevoelig is voor verleden schommelingen in het grootschalige atmosferische systeem dat het weer in de gebieden rond de noordelijke Atlantische Oceaan beïnvloed (hoofdstuk 4). Deze proxy is vervolgens gebruikt voor het reconstrueren van de intensiteit van het groeiseizoen over ruwweg de afgelopen 1300 jaar in Denemarken (hoofdstuk 6). Vast te stellen is dat een algemeen warmer wordend

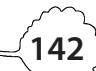


klimaat vaak voorafgegaan wordt door warmer wordende lentes. Gedurende het laatste millennium zijn de veranderingen in het groeiseizoen nauw verbonden geweest met de staat van welvaart van de bevolking, een verband waar ook in toekomst mee rekening gehouden zal moeten worden. 


\section{Acknowledgements}

I acknowledge and thank all the people that have supported, helped and/or inspired me becoming the person I am today, having completed my PhD research and the work that is in this book.

Little hints and nudges one way or another are equal to huge sways and movements, as they all form the path that leads from one moment to another. Therefore, however little our interaction along the way might have been, feel deeply appreciated. With that in mind, there are people that have had such an impact that I feel the need to address them more specifically.

Firstly, I thank my parents, who raised me with tremendous amounts of love and energy and infused me with interest in obtaining knowledge and seeking truth. Their continuous support and attention keep on inspiring me to push beyond. In the same spirit I thank my dear sister, Xezal, for her support and for always reminding me to strive be the best version of myself.

I want to express my deep gratitude and respect towards my mentor Rike. She has been my academic supervisor, coach, boss, leader and ultimately promotor for nearly 10 years at this point. That is a very long time, and the influence she has had on me as a person greatly exceeds just academic and professional teachings. I remember rushing to the University to reach her office after receiving an email of her seeking a student for a Bachelor Thesis project. That moment, in May 2012, determined the course of my life from then onwards.

I thank all the persons working at or associated with the Paleoecology, Marine Palynology, Earth Sciences and Physical Geography groups for having been great colleagues and friends during all those years. Thank you Appy, Bas, Francesca, Henk, Peter, Niels, Arjen, Joost, Johan, Johan, Tjerk, Marjolein, Mariska, Julian, Alex, Alexandra, Loes, Linda, Chloé, Natasja, Giovanni, Emmy, Emily, Nina, Robin, Margot, Caroline, Luc, Tjitske, Ilja, Wilma, Suning, Benjamin, Karin, Keechy, Tessa, Loes, Roos, Tom, Pieter, Heather, Willem-Jan, Tim, Bas, Bas, Ed, Muriel, Danghan, Jacob, Daniel, Joeri, Jannis, Sepher, Jude, Maarten, Maarten, Esther, Kim, Steven, Mark, Menno, Ruth, Marina, Thomas, Karel, Astrid, Catrien, Marloes, Iris, Evalien, and many, many more.

Timme, in those $\sim 10$ years you have been one of the pillars of the paleoecology 
group and your door was always open for science or real stuff, I want you to know I appreciated those moments.

Hugo, I have always regarded you as an elder brother-in-science, it was really cool being inspired by your PhD during my BSc, and later on actually working with you during my own PhD.

Leeli, you thought me so much about science, culture, and life, thank you so much!

Daan, thank you for all the fun and your metaphoric and literal guidance during my $\mathrm{PhD}$ and on fieldwork.

Wim thank you for scientific advice, but even more so for your life-advice, it has been very welcome at times.

Indeed, thank you to all co-authors, students, lab-staff, station managers and all others that are somehow involved in making this PhD research possible. Thanks to everyone at Kevo Research Station, Arctic Station on Disko, Herbarium Copenhagen, Kilpisjärvi Biological Station, Lammi Biological Station and Oulanka research station.

Rúna, our PhD subjects are as close as it gets within the Netherlands in our generation, which is not strange, since we share scientific lineage via Daan and others, and this shapes a bond that is strengthened through other shared interests and similarities. Thank you for being a kindred spirit.

Margot, you have been a study mate, friend, colleague, and so many other things to me. An all-round inspiration, thank you!

I thank many friends for standing at my side in life and inspiring me along the way. Amongst them: Luke, Michiel, Sybren, Rúna, Margot, Koen, Erin, 'the Apeldoorn group', the Squad, everyone aboard the Stålbas during our Svalbard adventure, and everyone at WS48.

I thank my paranymphs Sybren and Margot for literally standing at my side during a very important moment in my life. 

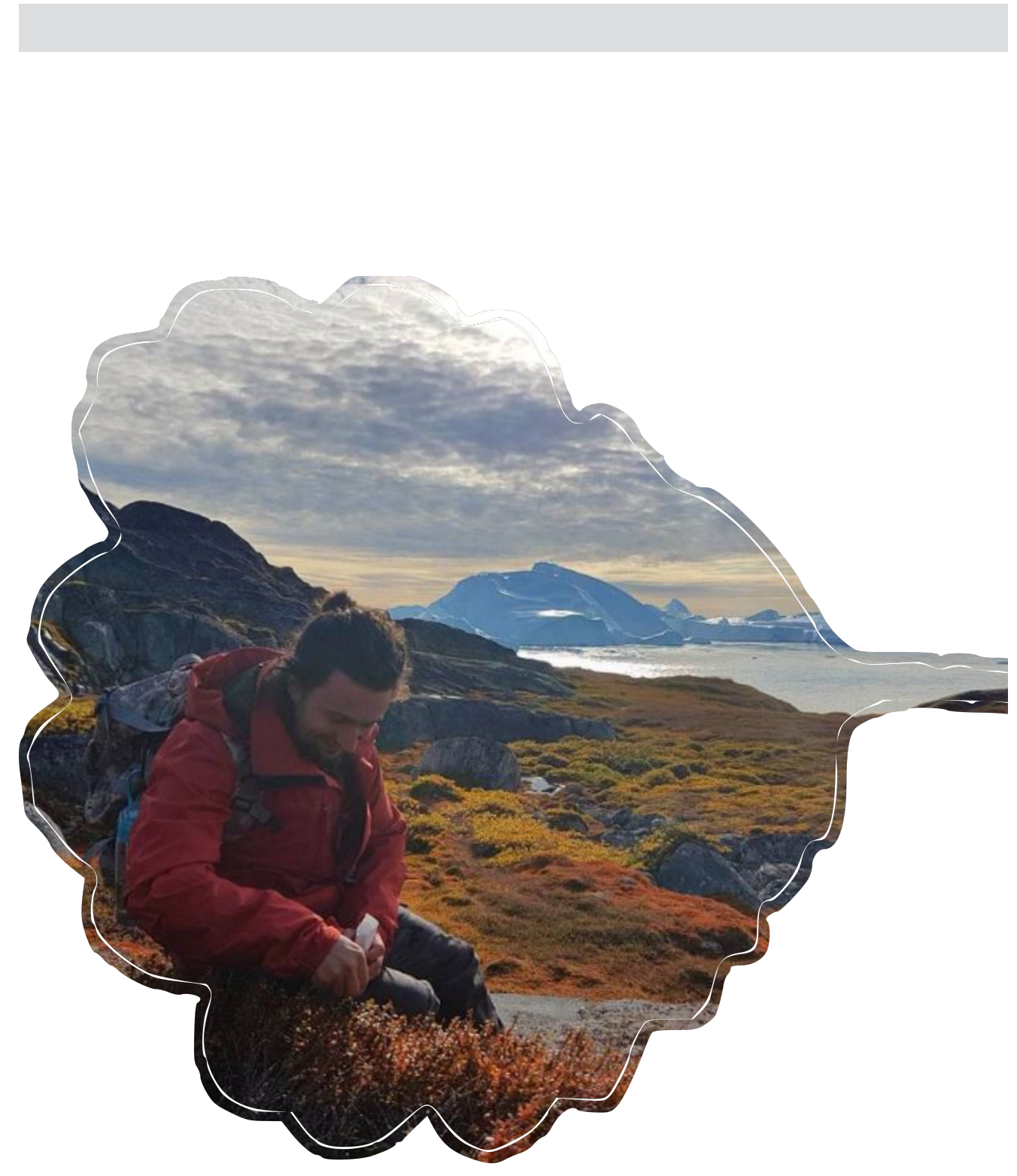

146 


\section{About the Author}

Fabian E. Z. Ercan was born in Utrecht at UMC on the Uithof on 16-03-1990. As young child, he frequently asked his parents to read him from one of his illustrated encyclopaedias for children. At the age of three, he owned his first microscope. Soon, the library was visited often to find books about dinosaurs and space, and Fabian knew he wanted to become an astronaut whilst also looking to find dinosaurs in the garden. During primary school, Fabian was eager to make presentations and writing assignments about his interests, and topics such as sea level rise on Tuvalu, evolution of polar bears and El Niño were investigated.

During high school (Atheneum), at Heerbeeck College in Best, his interests further developed while following a broad curriculum of courses including five languages, art, history, philosophy, and the natural sciences. A special interest developed towards biology, both human physiology and the natural world appealed to him. After graduating high school, Fabian enrolled at Utrecht University to study Biology. The biology program covered topics ranging from molecular biology to large scale ecology, crossing all kingdoms of life. During a field trip to Terschelling, one of the Dutch islands, Fabian was amazed by the scale and interaction of physical forces, astronomy, and the living world. He would follow courses in ecology from that point onwards and eventually paleoecology was where the combination of time, space and life would really hit the right spot.

Fabian wrote his Bachelor Thesis on climate sensitivity of Bristlecone pines, the world's longest living non-clonal organisms, with Prof. dr. F. Wagner-Cremer. During the Master program Environmental Biology, Fabian followed the track "Biomarine Sciences and Paleoecology", where he would elaborate on the climate sensitivity of Bristlecone pines for his mayor research thesis. For his minor research thesis, he would write on marine climate change in the arctic ocean of $\sim 190$ million years ago. To conclude the Master program, Fabian wrote a research proposal with Prof. dr. F. Wagner-Cremer, that would eventually develop into a granted NWO Open Competition PhD proposal, of which you have the result in front of you. 


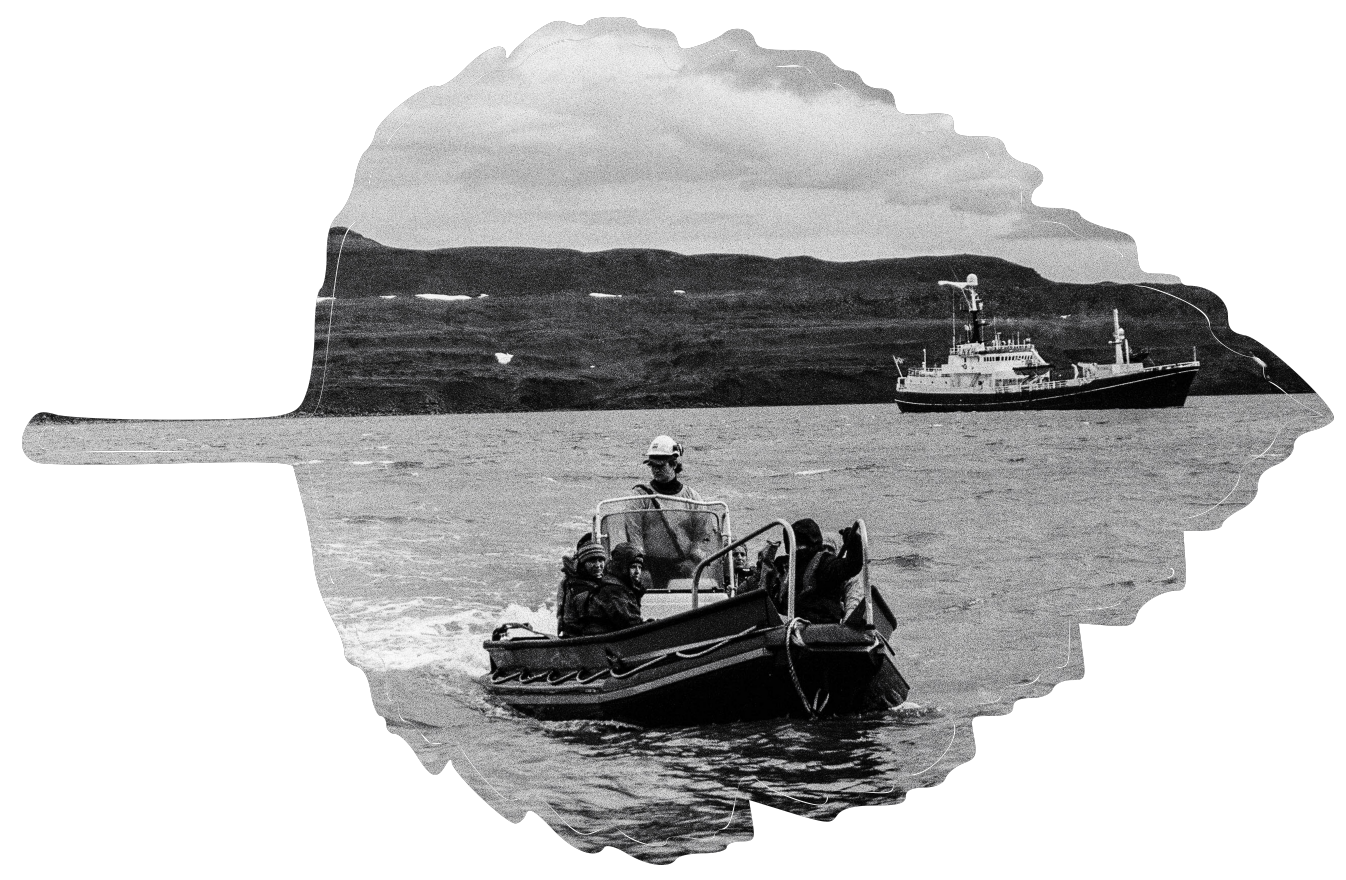

148 


\section{Curriculum Vitae}

01/08/2016-31/12/2021

PhD Researcher - Utrecht University

15/09/2015-31/07/2016

Junior Researcher - Utrecht University

01/10/2012-31/07/2016

University Teaching Assistant - Utrecht University

01/09/2013-31/07/2015

Master of Science, Environmental Biology - Utrecht University

Biomarine Sciences \& Palaeoecology

01/09/2009-31/07/2013

Bachelor of Science, Biology - Utrecht University

$2003-2009$

VWO, Natuur \& Gezondheid - Heerbeeck College, Best 


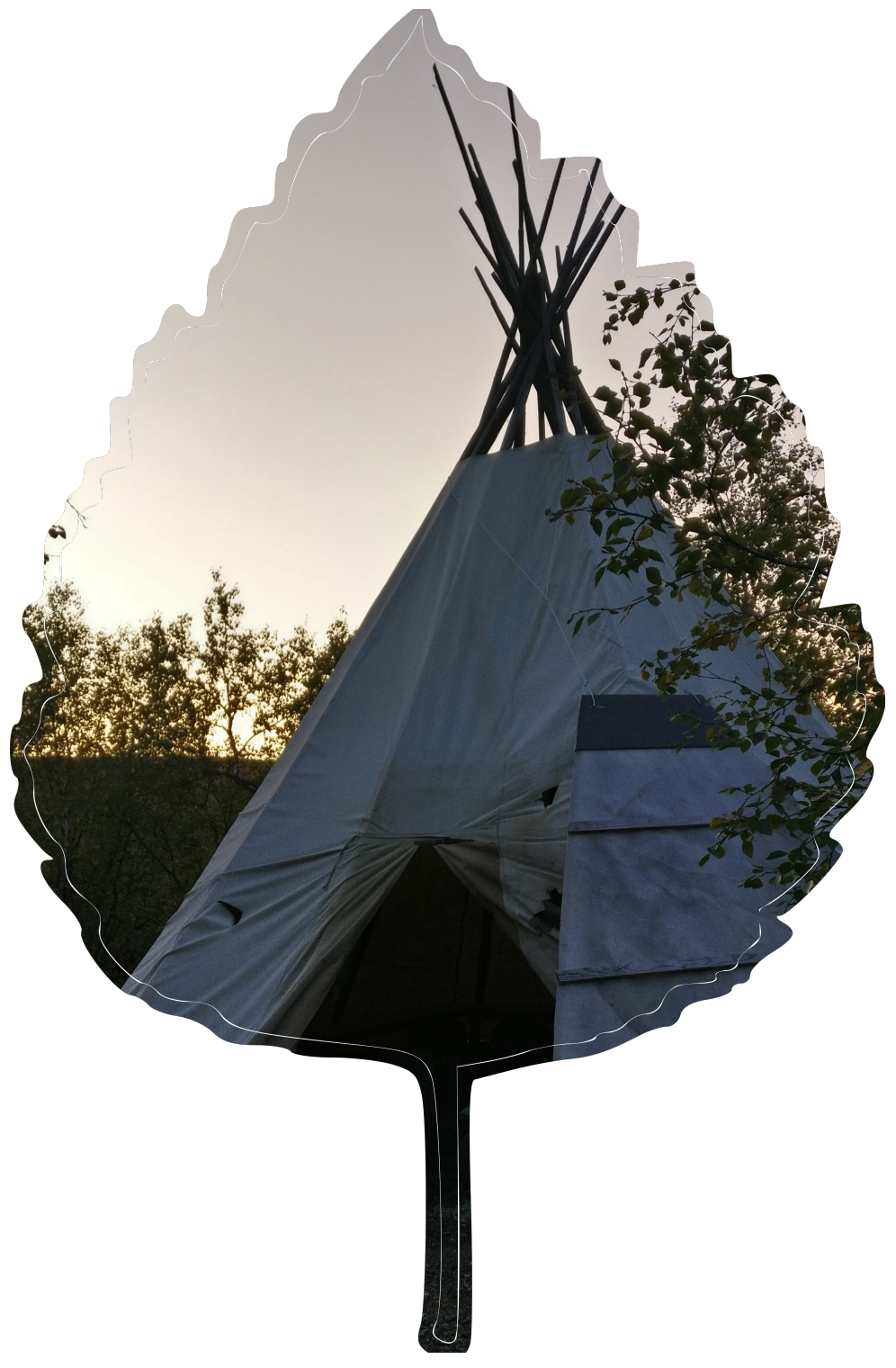

150 


\section{Fieldwork and Other Academic Activities}

- UNIS, Svalbard, Norway. Scientific Research Cruise, 2019

- Poland Fieldwork Campaign (participated), 2019

- TalTech, Tallinn, Estonia. Research exchange, 2019

- NAC2019 (Nederlands Aardwetenschappelijk Congres) Poster Presentation

Title: Microphenological response in B. nana to GDD (photo competition prize)

- KEVO60, Utjoki, Finland. Presentation, 2018

Title: Growing season changes over the past Millennium in northern high latitudes

- POLAR2018, Davos, Switzerland. Poster Presentation, 2018

Title: Effects of Growing Season Changes in Finland and Greenland

- Finland Fieldwork Campaign (organised), 2018

- NAC2018 (Nederlands Aardwetenschappelijk Congres) Poster Presentation, 2018

Title: Fennoscandian GDD5 gradient mirrored in leaf epidermal properties

- Copenhagen, Denmark, Herbarium Copenhagen Visit, 2017

- Greenland Fieldwork Campaign 2017 (organised), 2017

- NAC2016 (Nederlands Aardwetenschappelijk Congres) Poster Presentation, 2016

Title: Pollen reference collection digitization

- Finland Fieldwork Campaign (organised), 2016

- LPP 50 Poster Presentation. (Best Poster Prize), 2014

- NAC12 (Nederlands Aardwetenschappelijk Congres) Talk and Poster Presentation, 2014

Title: Annual resolution climate and meteorological signals in Bristlecone Pine. (For both entries)

- Organisational Assistant at the CONOSC Workshop, 2014 


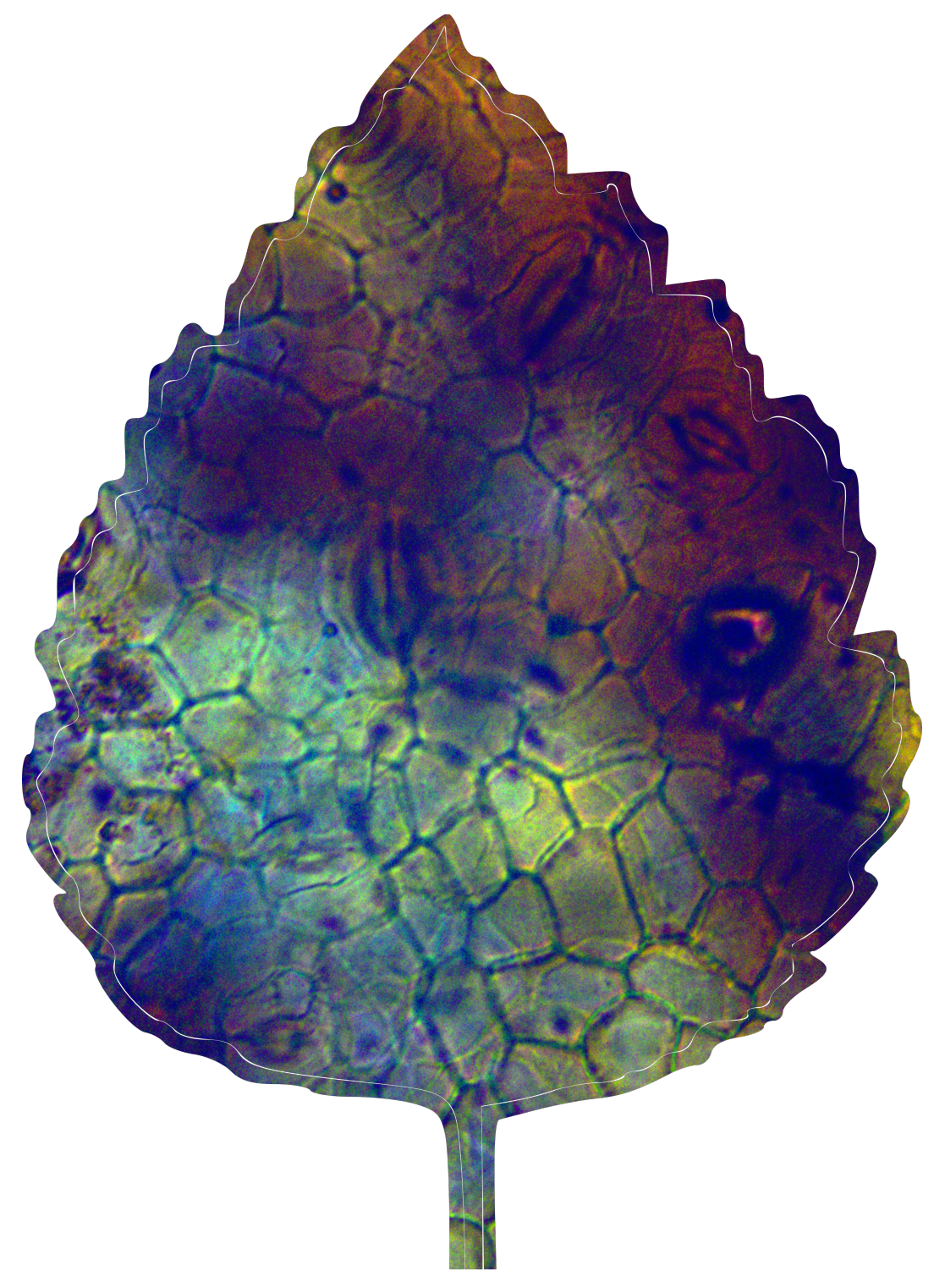

152 


\section{Other Publications}

Ercan FEZ, De Boer HJ, Wagner-Cremer F (2020) A growing degree day inference model based on mountain birch leaf cuticle analysis over a latitudinal gradient in Fennoscandia. Holocene 30:344-349. https://doi.org/10.1177/0959683619865605 - In this Thesis as Chapter 2

Ercan FEZ, Mikola J, Silfver T, Myller K, Vainio E, Słowińska S, Słowiński M, Lamentowicz M, Blok D, Wagner-cremer F (2021) Effects of experimental warming on Betula nana epidermal cell growth tested over its maximum climatological growth range. PLoS One 16:1-12. https://doi.org/10.1371/journal.pone.0251625 - In this Thesis as Chapter 3

Van De Schootbrugge B, Houben AJP, Ercan FEZ, Verreussel R, Kerstholt S, Janssen NMM, Nikitenko B, Suan G (2020) Enhanced Arctic-Tethys connectivity ended the Toarcian Oceanic Anoxic Event in NW Europe. Geol Mag 157:1593-1611. https:// doi.org/10.1017/S0016756819001262 
